\title{
Hepatoprotective Plants from Bangladesh: A Biophytochemical Review and Future Prospect
}

\author{
Razina Rouf, ${ }^{1}$ Puja Ghosh, ${ }^{2}$ Md. Raihan Uzzaman, ${ }^{2}$ Dipto Kumer Sarker, ${ }^{2}$ \\ Fatima Tuz Zahura, ${ }^{2}$ Shaikh Jamal Uddin $\mathbb{D}^{2}{ }^{2}$ and Ilias Muhammad ${ }^{3}$ \\ ${ }^{1}$ Department of Pharmacy, Bangabandhu Sheikh Mujibur Rahman Science and Technology University, \\ Gopalganj 8100, Bangladesh \\ ${ }^{2}$ Pharmacy Discipline, Life Science School, Khulna University, Khulna 9208, Bangladesh \\ ${ }^{3}$ National Center for Natural Products Research, School of Pharmacy, Research Institute of Pharmaceutical Sciences, \\ University of Mississippi, University, MS 38677, USA \\ Correspondence should be addressed to Shaikh Jamal Uddin; uddinsj@yahoo.com
}

Received 16 June 2021; Accepted 17 August 2021; Published 31 August 2021

Academic Editor: Ahmed Mediani

Copyright $\odot 2021$ Razina Rouf et al. This is an open access article distributed under the Creative Commons Attribution License, which permits unrestricted use, distribution, and reproduction in any medium, provided the original work is properly cited.

\begin{abstract}
Liver diseases are quite prevalant in many densely populated countries, including Bangladesh. The liver and its hepatocytes are targeted by virus and microbes, as well as by chemical environmental toxicants, causing wide-spread disruption of metabolic fuctions of the human body, leading to death from end-stage liver diseases. The aim of this review is to systematically explore and record the potential of Bangladeshi ethnopharmacological plants to treat liver diseases with focus on their sources, constituents, and therapeutic uses, including mechanisms of actions (MoA). A literature survey was carried out using Pubmed, Google Scholar, ScienceDirect, and Scopus databases with articles reported until July, 2020. A total of 88 Bangladeshi hepatoprotective plants (BHPs) belonging to 47 families were listed in this review, including Euphorbiaceae, Cucurbitaceae, and Compositae families contained $20 \%$ of plants, while herbs were the most cited (51\%) and leaves were the most consumed parts (23\%) as surveyed. The effect of BHPs against different hepatotoxins was observed via upregulation of antioxidant systems and inhibition of lipid peroxidation which subsequently reduced the elevated liver biomarkers. Different active constituents, including phenolics, curcuminoids, cucurbitanes, terpenoids, fatty acids, carotenoids, and polysaccharides, have been reported from these plants. The hepatoameliorative effect of these constituents was mainly involved in the reduction of hepatic oxidative stress and inflammation through activation of Nrf2/HO- 1 and inhibition of NF- $\kappa \mathrm{B}$ signaling pathways. In summary, BHPs represent a valuable resource for hepatoprotective lead therapeutics which may offer new alternatives to treat liver diseases.
\end{abstract}

\section{Introduction}

The liver is one of the vital organs in the human body that is responsible for metabolism, excretion, and regulation of body homeostasis [1]. Therefore, the liver and its hepatocytes are the major targets of various toxicants (i.e., heavy metals, toxins, drugs, and other chemicals), microbes, and viral infections [2]. Harmful effects of the abovementioned factors on the liver and its hepatocytes include inflammatory (i.e., hepatitis) or non-inflammatory (i.e., hepatosis) liver diseases, liver fibrosis (i.e., cirrhosis), jaundice, and alcoholic liver disease. Liver diseases are now considered as one of the major global health problems, particularly in low- and middle-income countries where it gives the highest burden but largely neglected [3]. Liver disease affects millions of people worldwide, with about 2 million dying annually, and the rates of affecting are increasing sharply over the years irrespective of age, sex, region, and race [4, 5]. Liver diseases, including jaundice and chronic viral hepatitis, as well as nonalcoholic fatty liver, are one of the major treatment burdens in Bangladesh. About eight million people are reported to have viral hepatitis, Hep B (HBV) and C (HCV), and also, frequent outbreak of hepatitis $\mathrm{A}(\mathrm{HAV})$ and $\mathrm{E}$ (HEV) have been reported in Bangladesh [6]. It is estimated 
that one in five maternal deaths associated with acute jaundice occurred in Bangladesh as well as increasing trend of fatty liver diseases [7]. Drugs that are currently available for the treatment of liver diseases suffer a number of shortcomings including side effects, poor bioavailability, stability, and selectivity [8]; thus, it is necessary to search new drugs with optimum efficacy, stability, selectivity, and safety for the treatment of liver diseases.

Medicinal plants play a key role in human health, and about $80 \%$ of the world's population in developing countries relies on the use of plant-based traditional medicine [9]. The use of medicinal plants for the treatment of liver diseases has a long history. Scientific study has increased with ethnopharmacological plants that possess strong hepatoprotective activity [10]. The term "hepatoprotective" means either to protect or prevent the liver damage. A number of scientific studies on such local plants and their herbal formulations around the world have been recorded as hepatoprotective [8, 10-17]. Numerous phytoconstituents have already proved to protect liver diseases in both in vitro and in vivo settings [18-21]. It is obvious that traditional herbal medicines are a natural treasure because of their chemical diversity, affordability, availability, few side effects, and diverse pharmacological activity $[8,22]$. It is established that traditional knowledge on the medicinal plants has indispensable importance on new drug discovery [23], which attracted immense interest by the scientists over many decades.

The use of medicinal plants for the treatment of different diseases by Indo-Aryans has been reported in Rigveda in 4500-1600 BC [24, 25]. Bangladesh, which belongs to the Indian subcontinent, also possesses a rich heritage of herbal medicines [26]. About 500 species of medicinal plants are growing in Bangladesh, and among these, more than 250 species are currently in use for the preparation of herbal medicines using the traditional approach and about $80 \%$ of rural population of Bangladesh depends on traditional herbal medicine for their primary healthcare [25].

Ethnobotanical use of Bangladeshi medicinal plants has a long history of use in the treatment of liver diseases including jaundice, ascites, liver cirrhosis, hepatitis, liver enlargement, inflammatory liver, sclerosis of the liver, and other liver diseases [26]. Traditional healers of Bangladesh have strong believed on alternative natural plant-based medicine that has few side effects than modern synthetic medicine. The traditional medicinal practitioner, Kabiraj, have developed a number of herbal and ayurvedic formulations in Bangladesh for the treatment of liver diseases [27]. This is one of the affordable and accessible treatment options in liver diseases by rural people because of low cost and lack of access to modern treatment [7]. It is well known that plant-derived natural molecules including flavonoids, terpenoids, sterols, and antioxidants possess diverse therapeutic effects including hepatoprotective activity [10]. The presence of these bioactive phytoconstituents has made these traditionally used plants highly effective against liver diseases. However, there is no up-to-date report on ethnopharmacological and phytochemical investigations for active constituents of Bangladeshi medicinal plants used to treat liver diseases. The aim of this review is to summarize the potential of active compounds from plants used traditionally for liver diseases, as well as the underlying proposed mechanisms of action by compiling both in vitro and in vivo studies.

\section{Literature Search Strategy and Data Extraction}

Plants that are currently used locally to treat liver diseases are listed in two ethnopharmacological books, namely, the Medicinal Plants of Bangladesh with Chemical Constituents and Uses and the Medicinal Plants of Bangladesh [26, 28]. A comprehensive list of such plants (Table 1) was developed from these two book sources. Furthermore, a complete literature survey on each plants was conducted by PubMed, Scopus, Google Scholar, Web of Sciences, and ScienceDirect databases, using keywords "Bangladeshi medicinal plants" and "plant extracts", and then refined with the additional keywords "hepatoprotective," "liver diseases," "hepatoprotective activity," and "isolated compound." In this review, the following surveys were conducted, including (a) in vivo, in vitro, and clinical studies of plant extracts and compounds for liver diseases, (b) studies concerning the concentrations, doses, and route of administration of extracts and/compounds, and (c) studies concerning MoA associated with the hepatoprotective activity of extracts and/ or constituents.

\section{Results and Discussion}

3.1. Hepatoprotective Plants. In this review, a total of 88 species belonging to 47 families and more than 75 genera were selected based on various liver diseases including jaundice, ascites, liver cirrhosis, hepatitis, liver enlargement, inflammatory liver, and sclerosis of the liver $[26,28]$. Table 1 shows the common names, plant parts, dosage form of extracts, and recommended use for liver diseases of these plants, and the most used form of preparation was juice (21\%), hydroalcoholic extract (14\%), and the decoction or infusion (5-19\%). The distribution of various species with respect to families is shown in Figure 1, while the percentage distribution of various categories of samples, such as herbs, shrubs, and trees with $51 \%, 28 \%$, and $21 \%$, respectively, is shown in Figure 2. Finally, Figure 3 illustrates that about $43 \%$ of the total recorded plants are distributed all over the country, including the districts of Chittagong, Dhaka, Mymensing, Sylhet, and Rajshahi.

Among the plant parts employed for ethnopharmacological use, leaves were highly utilized with $23 \%$, followed by roots, fruits, whole plants/aerial parts, seeds, bark, rhizomes, and flowers $(19 \%, 18 \%, 12 \%, 6 \%, 5 \%, 3 \%$, and $2 \%$, respectively) (Figure 4 ).The methods of preparation of each plant parts showed the unique indigenous knowledge of the traditional healers $[25,29]$; thus, different methods of preparation carry different active constituents. Here is a summary of active plants from various plant families. 
TABLE 1: Traditional use and other information of Bangladeshi medicinal plants used to treat different liver diseases [26, 28].

\begin{tabular}{|c|c|c|c|c|c|c|}
\hline Name of plants & Local name & Habit & Family & Used parts & Form of use & Diseases \\
\hline Allamanda cathartica $\mathrm{L}$. & Malatilata & Shrub & Apocynaceae & Bark & NA & Ascites \\
\hline Alocasia indica Roxb. & Mankachu & Herb & Araceae & Tuber & NA & Jaundice \\
\hline $\begin{array}{l}\text { Aloe barbadensis/A. vera } \\
\text { L. }\end{array}$ & Ghritakumari & Herb & Liliaceae & Leaves & Juice & Jaundice \\
\hline Aloe indica Linn. & Ghritakumari & Herb & Liliaceae & Leaves & Juice & Jaundice \\
\hline Alpinia calcarata Rose. & Bara kulanjan & Herb & Zingiberaceae & Rhizome & NA & Liver disease \\
\hline Alpinia nigra Burtt. & Jangli ada & Herb & Zingiberaceae & Rhizome & Crushed rhizome & Liver disease \\
\hline $\begin{array}{l}\text { Amaranthus spinosus } \\
\text { Linn. }\end{array}$ & Katanotey & Herb & Amaranthaceae & $\begin{array}{l}\text { Leaves and } \\
\text { roots }\end{array}$ & Decoction & Jaundice \\
\hline Anagallis arvensis Linn. & Blue pimpernel & Herb & Primulaceae & Whole plant & NA & Liver disease \\
\hline $\begin{array}{l}\text { Andrographis paniculata } \\
\text { Burm. f. }\end{array}$ & Kalomegh & Herb & Acanthaceae & Leaves & Juice & Liver disease \\
\hline $\begin{array}{l}\text { Apanamixis polystachya } \\
\text { Wall. }\end{array}$ & $\begin{array}{l}\text { Roina and } \\
\text { tiktaraj }\end{array}$ & Tree & Meliaceae & Bark & NA & Liver disease \\
\hline Argenome Mexicana Linn. & Shialkata & Herb & Papaveraceae & Whole plant & Latex and extract of plants & Jaundice \\
\hline $\begin{array}{l}\text { Asparagus racemosus } \\
\text { Wild. }\end{array}$ & Shatamuli & Herb & Liliaceae & Whole plant & NA & Jaundice \\
\hline Averrhoa carambola Linn. & Kamranga & Tree & Oxalidaceae & Fruits & Fresh fruit & Jaundice \\
\hline $\begin{array}{l}\text { Baliospermum montanum } \\
\text { Wild. }\end{array}$ & Dantimul & Shrub & Euphorbiaceae & Root & Decoction & Jaundice \\
\hline Bixa Orellana Linn. & $\begin{array}{l}\text { Latkan and } \\
\text { annato }\end{array}$ & Tree & Bixaceae & Root & Aqueous extract & Jaundice \\
\hline Boerhaavia diffusa Linn. & Punarnava & Herb & Nyctaginaceae & $\begin{array}{l}\text { Leaves and } \\
\text { roots }\end{array}$ & Juice & $\begin{array}{l}\text { Jaundice and } \\
\text { ascites }\end{array}$ \\
\hline Borassus flabellifer Linn. & Tal gachh & Tree & Palmae & Fruit & Palm sugar and candy & Liver disease \\
\hline $\begin{array}{l}\text { Caesalpinia bonducella } \\
\text { Linn. }\end{array}$ & Nata karanja & Shrub & Caesalpiniaceae & Leaves & NA & Liver disease \\
\hline $\begin{array}{l}\text { Caesalpinia pulcherrima } \\
\text { Linn. }\end{array}$ & Krishnachura & Tree & Caesalpiniaceae & Leaves & NA & Liver disease \\
\hline Cajanus cajan Linn. & Arhar and tur & Shrub & Papilionaceae & Leaves & Juice & Jaundice \\
\hline $\begin{array}{l}\text { Calycopteris floribunda } \\
\text { Lam. }\end{array}$ & Goache lata & Shrub & Combretaceae & Fruits & Juice & Jaundice \\
\hline $\begin{array}{l}\text { Carthamus tinctorius } \\
\text { Linn. }\end{array}$ & Kajirah & Herb & Compositae & Flowers & Hot infusion & Jaundice \\
\hline Cassia fistula Linn. & Bandar lathi & Tree & Caesalpiniaceae & Seeds & NA & Jaundice \\
\hline Carica papaya Linn. & Pepe & Tree & Carieaceae & Fruits & Fresh fruits & Liver disease \\
\hline $\begin{array}{l}\text { Chenopodium album } \\
\text { Linn. }\end{array}$ & Bethusag & Herb & Chenopodiaceae & Leaves & Juice & Liver disease \\
\hline Citrullus colocynthis Linn. & Makal & Herb & Cucurbitaceae & Roots & NA & $\begin{array}{l}\text { Ascites and } \\
\text { jaundice }\end{array}$ \\
\hline Citrullus lanatus Thunb. & Tarmuj & Herb & Cucurbitaceae & Fruits & Fresh fruits & Liver disease \\
\hline Clitoria ternatea Linn. & $\begin{array}{l}\text { Aparajita and } \\
\text { nila }\end{array}$ & Herb & Papilionaceae & Seeds & $\begin{array}{l}\text { Roasted and powdered } \\
\text { seeds }\end{array}$ & Ascites \\
\hline Corchorus olitorius Linn. & Tosha pat & Herb & Tiliaceae & Leaves & Juice & Ascites \\
\hline Corchorus capsularis Linn. & Deshi pat & Herb & Tiliaceae & Leaves & Juice & Liver disease \\
\hline Croton caudatus Geisel. & Nan-bhantur & Shrub & Euphorbiaceae & $\begin{array}{l}\text { Leaves and } \\
\text { buds }\end{array}$ & NA & Liver disease \\
\hline Croton oblongifolius Roxb. & Baragachi & Tree & Euphorbiaceae & $\begin{array}{l}\text { Bark and } \\
\text { roots }\end{array}$ & NA & Liver disease \\
\hline $\begin{array}{l}\text { Curculigo orchioides } \\
\text { Gaertn. }\end{array}$ & Talamuli & Herb & Amaryllidaceae & Rhizomes & NA & Jaundice \\
\hline Curcuma longa Linn. & Halud and haldi & Herb & Zingiberaceae & Rhizome & Essential oils & Liver disease \\
\hline Cucumis melo Linn. & Kharmuj & Herb & Cucurbitaceae & Seeds & Extract of seeds & Ascites \\
\hline Cuscuta reflexa Roxb. & Swarnalata & Herb & Convolvulaceae & Whole plant & Crushed of plant & Jaundice \\
\hline Daucas carota Linn. & Gajor & Herb & Umbelliferae & Rhizome & Fresh rhizome & Jaundice \\
\hline Ecbolium viride Forsk. & Nilkanta & Shrub & Acanthaceae & Roots & NA & Jaundice \\
\hline Eclipta alba Linn. & $\begin{array}{l}\text { Kesuti and } \\
\text { keshraj }\end{array}$ & Herb & Compositae & Whole plant & Decoction/juice & Jaundice \\
\hline Elephantopus scaber Linn. & Gojilata & Herb & Compositae & Roots & Crushed roots & Liver disease \\
\hline Eleusine indica Linn. & Malangakuri & Herb & Gramineae & Roots & NA & Liver disease \\
\hline
\end{tabular}


TABle 1: Continued.

\begin{tabular}{|c|c|c|c|c|c|c|}
\hline Name of plants & Local name & Habit & Family & Used parts & Form of use & Diseases \\
\hline Embelia ribes Bur.f. & Biranga & Shrub & Myrsinaceae & Fruits & NA & Jaundice \\
\hline Euphorbia tirucalli Linn. & Lanka sij & Shrub & Euphorbiaceae & Whole plant & Juice & Jaundice \\
\hline Flacourtia jangomas Lour. & Paniala & Shrub & Flacourtiaceae & Fruit & NA & Liver disease \\
\hline $\begin{array}{l}\text { Glycosmis pentaphylla } \\
\text { Corr. }\end{array}$ & Motkilagachh & Shrub & Rutaceae & Leaves & Infusion & Jaundice \\
\hline Hedyotis corymbosa Linn. & Khetpapra & Herb & Rubiaceae & $\begin{array}{l}\text { Whole plant } \\
\text { Enter plant }\end{array}$ & $\begin{array}{c}\text { Methanolic extract } \\
\text { NA }\end{array}$ & $\begin{array}{l}\text { Liver disease } \\
\text { Jaundice }\end{array}$ \\
\hline $\begin{array}{l}\text { Hypericum japonicum } \\
\text { Thunb. }\end{array}$ & Bassanta & Herb & Hypericaceae & Whole plant & NA & Liver disease \\
\hline $\begin{array}{l}\text { Hygrophila auriculata } \\
\text { Schum. }\end{array}$ & Talmakhna & Herb & Acanthaceae & Seeds & Methanolic extract & Liver disease \\
\hline Indigofera tinctora Linn. & Neel and indigo & Shrub & Papilionaceae & Roots & NA & Hepatitis \\
\hline Ipomoea aquatica Forsk. & Kalmishak & Herb & Convolvulaceae & Stems/leaves & Fresh juice or cooking & Liver complaints \\
\hline Justicia gendarussa Burm. & Jagatmadan & Shrub & Acanthaceae & & Decoction & Jaundice \\
\hline Kalanchoe pinnata Lam. & Patharkuchi & Herb & Crassulaceae & Le & Juice & \\
\hline Lagenaria siceraria Mol. & Lau and kodu & Shrub & Cucurbi & & Decoction with sugar & \\
\hline rmis Linn. & Mehedi & Tree & Lythraceae & Bark & Decoction & Jaundice \\
\hline s Linn. & Pudina & Herb & Labiatae & Aerial part & Juice & Jaundice \\
\hline Meyna spinosa Roxb. & Moyna & Shrub & Rubiaceae & Fruits & Decoction of frozen fruits & Liver disease \\
\hline $\begin{array}{l}\text { Momordica charantea } \\
\text { Linn. }\end{array}$ & $\begin{array}{l}\text { Uchahe and } \\
\text { karalla }\end{array}$ & Herb & Cucurbitaceae & Leaves/fruits & Juice & Jaundice \\
\hline Moringa oleifera Lamk. & Sajnagachh & Tree & Moringaceae & Fruits & NA & Diseases of the liver \\
\hline $\begin{array}{l}\text { Mussaenda glabrata } \\
\text { Hutch. }\end{array}$ & Nagabali & Shrub & Rubiaceae & Leaves & Crushed with milk & Jaundice \\
\hline Nelumbo nucifera Gaertn. & Podma and lotus & Herb & Nymphaeaceae & Flowers & Crushed of flower & Liver disease \\
\hline $\begin{array}{l}\text { Nymphoides cristatum } \\
\text { Lour. }\end{array}$ & Chandmala & Herb & Gentianaceae & Whole plant & NA & Jaundice \\
\hline Ocimum basilicum Linn. & Babuitulshi & Shrub & Labiatae & $\begin{array}{l}\text { Leaves/ } \\
\text { flowers }\end{array}$ & Juice & $\begin{array}{l}\text { Sclerosis of the } \\
\text { liver }\end{array}$ \\
\hline Paederia foetida Linn. & Gondhabadali & Shrub & Rubiaceae & $\begin{array}{l}\text { Roots and } \\
\text { barks }\end{array}$ & NA & Liver pain \\
\hline Pavetta indica Linn. & Kukurchura & Shrub & Rubiaceae & Root & $\begin{array}{l}\text { Pulverized with ginger and } \\
\text { rice water }\end{array}$ & Ascites \\
\hline Phyllanthus acidus Linn. & $\begin{array}{l}\text { Horbori and } \\
\text { orbori }\end{array}$ & Tree & Euphorbiaceae & Fruits & Fresh fruits & Tonic to the liver \\
\hline Phyllanthus emblica Linn. & Amlaki & Tree & Euphorbiaceae & Fruits & Fresh fruits & Jaundice \\
\hline $\begin{array}{l}\text { Phyllanthus freternus } \\
\text { Web. }\end{array}$ & Bhui-amla & Herb & Euphorbiaceae & Roots & Fresh roots & Jaundice \\
\hline Piper longum Linn. & Pipul & Shrub & Piperaceae & Fruits & Unripe fruits & Jaundice \\
\hline Piper nigrum Linn. & Golmorich & Shrub & & & Crushed of fruits & \\
\hline Plumbago indica Linn. & Lalchita & Herb & Plumbaginaceae & Root & NA & Liver disease \\
\hline Portulaca oleracea Linn. & Nuneshak & Herb & Portulacaceae & Whole plant & Juice & Liver disease \\
\hline Rumex vesicarius Linn. & Tok-palong & Herb & Polygonaceae & Seeds & Fresh seeds & Jaundice \\
\hline $\begin{array}{l}\text { Saccharum officinarum } \\
\text { Linn. }\end{array}$ & $\begin{array}{l}\text { Aakh and } \\
\text { kuishar }\end{array}$ & Shrub & Gramineae & Stem & Juice & Jaundice \\
\hline $\begin{array}{l}\text { Semecarpus anacardium } \\
\text { Linn. f. }\end{array}$ & Bhela & Tree & Anacardiaceae & Ripe fruits & Fresh ripe fruits & Ascites \\
\hline Solanum nigram Linn. & Phuti begoon & Herb & Solanaceae & Aerial parts & Juice & Liver enlargement \\
\hline Solanum torvum Sw. & & Shrub & & Leaves/f & Extract of fruits and leaves & Liver enl \\
\hline Sonchus wightianus DC. & & & & & NA & \\
\hline Spinacia oleracea Linn. & Palong shak & Herb & Chenopodiaceae & & NA & Liver inflammation \\
\hline Syzygium jambos Linn. & Golap jam & Tree & Myrtaceae & Fruits & Fresh fruits & Liver complaints \\
\hline Tamarix troupii Hole. & & Shrub & & Leaves & Ash of leaves & Hepator \\
\hline Tephrosia purpurea Linn. & Sarpunkha & & & & NA & \\
\hline Terminalia arjuna Roxb. & Arjun gach & Tree & & & & Liver cirrhosis \\
\hline Terminilia bellirica Roxb. & Bohera & Tree & Combretaceae & & Decoction & Hepatitis \\
\hline Terminilia chebula Retz. & Hartaki & Tree & Combretaceae & Fruits & Decoction & \\
\hline Tirospora cordifolia Linn. & Guloncha lata & Shrub & Menispermaceae & Leaves/stems & NA & Jaundice \\
\hline $\begin{array}{l}\text { Trianthema } \\
\text { portulacastrum Linn. }\end{array}$ & Swet punarnava & Herb & Aizoaceaee & Roots & Decoction & Liver troubles \\
\hline Trichosanthes dioica Roxb. & Potol & Herb & Cucurbitaceae & Leaves & Juice & \\
\hline Wedelia chinensis Merr. & Kesharaj & Herb & Compositae & Whole plant & NA & Liver enlargement \\
\hline
\end{tabular}




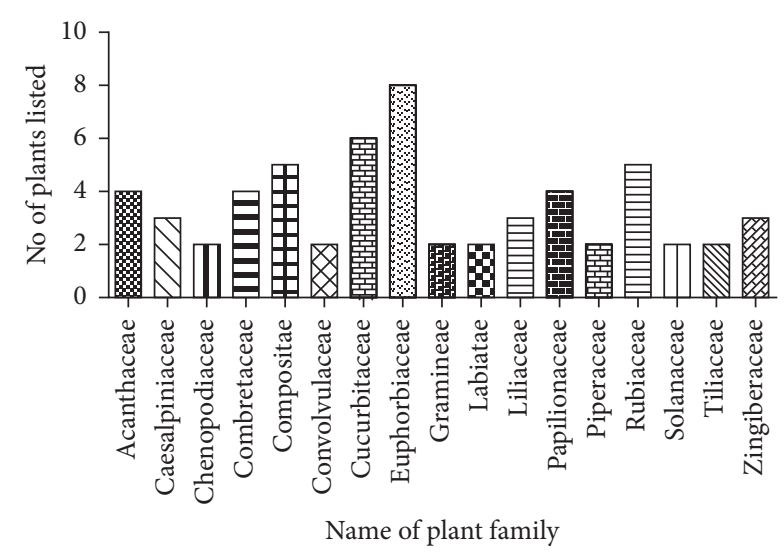

FIgURE 1: Graphical presentation of the Bangladeshi medicinal plant family containing more than one plant traditionally used to treat liver diseases.

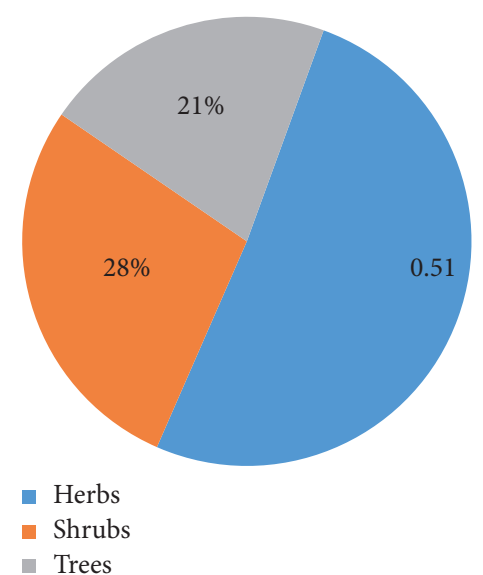

Figure 2: Bangladeshi medicinal plants with their \% of habit traditionally used to treat liver disease.

3.1.1. Plants from Euphorbiaceae. Euphorbiaceae is a large family containing about 300 genera and over 5000 species [30]. The ethnomedicinal significance of this family has a long tradition because of its diverse secondary metabolites [31]. The present review demonstrated that, among the 47 families, Euphorbiaceae possesses eight species, including Baliospermum montanum, Croton caudatus, Croton oblongifolius, Euphorbia tirucalli, Flacourtia jangomas, Phyllanthus acidus, Phyllanthus emblica, and Phyllanthus freternus, that have been traditionally used to treat liver diseases (Table 1). B. montanum, locally known as Dantimul, is a leafy branched undershrub, distributed throughout Bangladesh and India. Decoction of the roots has been used to treat jaundice in Bangladesh [26], as well as in the Ayurvedic system of medicine [32]. A number of in vivo and in vitro hepatoprotective models have been developed for extract or isolated compounds to prevent or cure liver toxicity induced by various hepatotoxins, such as thioacetamide (TAA), carbontetrachloride $\left(\mathrm{CCl}_{4}\right)$, and paracetamol (APAP) [33]. The liver protective effect of alcoholic and aqueous extract of $B$. monatum root was reported by restoring the biochemical changes induced by paracetamol $(2 \mathrm{mg} / \mathrm{kg})$ in rat, and the results were comparable to the silymarin (Table 2). The dosedependent hepatoprotective effects of methanolic fraction and its subfractions in either $\mathrm{CCl}_{4^{-}}$, thioacetamide-, or paracetamol-induced liver damage rats were comparable to the protective effect of silymarin at $100 \mathrm{mg} / \mathrm{kg}$, and the protective effect of root extracts was believed to be for their antioxidant effects (Figure 5) [34-37].

3.1.2. Plants from Cucurbitaceae. There are six local species from five genera of the Cucurbitaceae family [38] which have been used to treat liver disease (Table 1). Among these, the fruits of C. colocynthis and C. lanatus are cross compatible and reported to protect hepatic injury induced by different hepatotoxins (Table 2), and the fruit and root of $C$. colocynthis have been used for the treatment of jaundice $[39,40]$. Initial toxicity study of its methanolic extract in mice was found to be safe upto a dose of $2000 \mathrm{mg} / \mathrm{kg}$ [40]. A number of in vivo investigations of the crude extract showed dose-dependent hepatoprotective activity induced by hepatotoxins, such as APAP, $\mathrm{CCl}_{4}$, cisplatin, or polluted water, in rats (Table 2). The alcoholic extract of C. colocynthis fruits showed protective activity against APAPinduced hepatotoxicity in rats at $200-300 \mathrm{mg} / \mathrm{kg}$ via decreasing the elevated level of liver enzymes, and the results were comparable to the marketed preparation Liv. $52(1 \mathrm{~mL} / \mathrm{kg})$ and silymarin $(100 \mathrm{mg} / \mathrm{kg})$, respectively [40, 41]. Pretreatment with chloroform fractions of this fruits has also been reported to reduce the impact of $\mathrm{CCl}_{4}$ and lipopolysaccharide toxicity on the serum liver markers which was comparable to the Chinese drug Bifendate pills (a synthetic intermediate of schisandrin C). The mechanism of the protective effect of $C$. colocynthis might be involved in the reduction of cellular oxidative stress through increasing antioxidant defense systems as well as upregulating the cellular antioxidant enzymes level [40, 42-45].

The juice of C. lanatus (local name: tarmuj) fruit pulp possesses antioxidant activity and protects liver damage in ethanol-induced liver toxicity in rat via increasing cellular glutathione (GSH) and catalase (CAT) enzymes, which supports the traditional use to treat liver damage [46]. The dose-dependent liver protective effect of $\mathrm{MeOH}$ or $\mathrm{EtOH}$ seed extracts $(200-400 \mathrm{mg} / \mathrm{kg})$ showed a significant reduction of oxidative stress and improved drug metabolizing enzyme activity in the liver [47-49]. The seed extracts also protect liver fibrosis via inhibiting alpha-smooth muscle actin ( $\alpha$-SMA) and transforming growth factor- $\beta 1$ (TGF- $\beta 1$ ) protein expression in $\mathrm{CCl}_{4}$-induced hepatotoxicity in the rat model [47], whereas the EtOH extracts of the leaf of C. lanatus ameliorate and reverse damage of the rat liver tissues induced by $\mathrm{CCl}_{4}$ via reduced congestion and necrosis as well as normalized serum AST, ALT, ALP, and bilirubin concentrations [50].

Momordica charantea has been used for various medicinal values, especially diabetes, which is recommended for jaundice as well (Table 1). In India, the fruit juice or leaf decoction has been used traditionally for hepatitis and jaundice [51, 52]. Mada showed that the extract of $M$. charantea is quite safe and found the $\mathrm{LD}_{50}$ was more than $5000 \mathrm{mg} / \mathrm{kg}$ [53]. A number of reports showed that the hydroalcoholic or aqueous extract of $M$. charantea leaves 


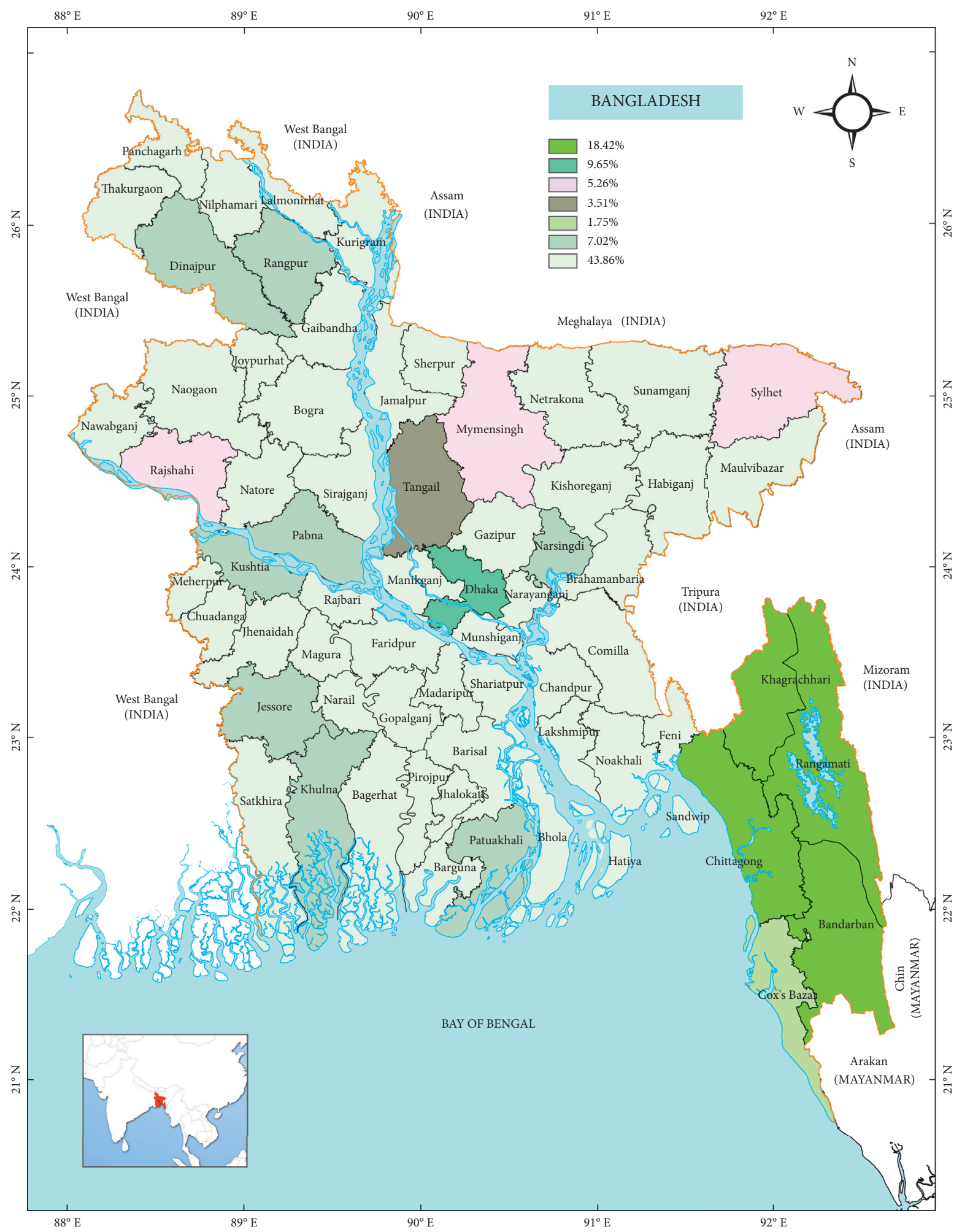

Figure 3: Percent distribution of Bangladeshi hepatoprotective plants listed in Table 1 [26].

dose-dependently (100-400 $\mathrm{mg} / \mathrm{kg})$ protect hepatotoxicity induced by $\mathrm{CCl}_{4}$ in the rat model in which the extract supplementation restored the elevated level of different liver toxicity markers, and the results were comparable to marketed liver protective preparation silymarin $(50 \mathrm{mg} / \mathrm{kg})$ or
Liv $52(5 \mathrm{~mL} / \mathrm{kg})$ [53-55]. The aqueous extract of $M$. charantea fruit also reported to protect dose dependently liver toxicity in mice or rats by reducing the elevated liver markers as well as attenuating oxidative stress (Table 2) $[51,56,57]$. 


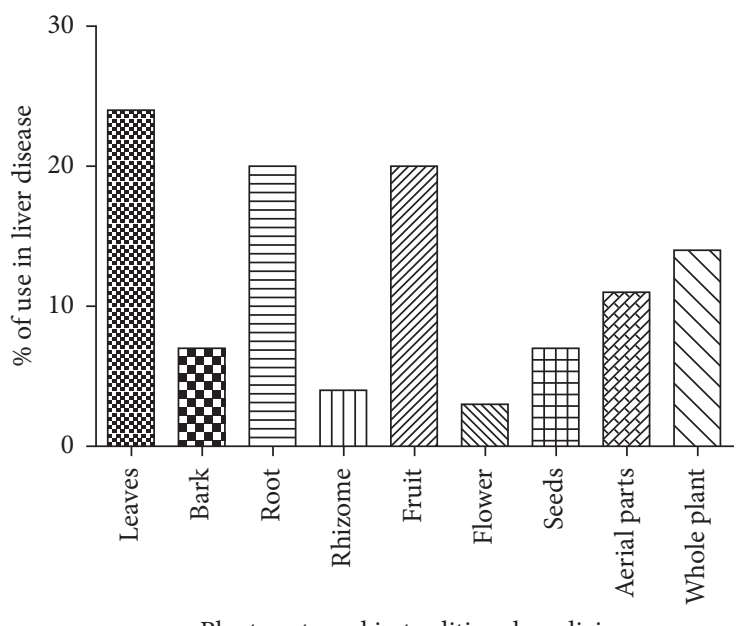

Figure 4: Percentage of plant parts used in treatment of liver disease and jaundice. It is shown that leaves, root, and fruits are the most popular plant parts of Bangladeshi medicinal plants used to treat liver diseases.

TABLE 2: Hepatoprotective activity of Bangladeshi medicinal plants.

\begin{tabular}{|c|c|c|c|c|c|c|}
\hline Plant name & $\begin{array}{l}\text { Extract and plant part } \\
\text { used }\end{array}$ & Test model & Dose & Route & Hepatoameliorative effects & Ref. \\
\hline \multirow{7}{*}{ A. barbadensis } & AQ extract of leaves & $\begin{array}{l}\text { APAP-induced hepatotoxicity in } \\
\text { albino rats }\end{array}$ & $\begin{array}{l}250 \text { and } \\
500 \mathrm{mg} / \mathrm{kg}\end{array}$ & Oral & $\begin{array}{l}\downarrow \text { the elevated AST, ALT, and ALP levels } \\
\text { and restored the depleted liver thiol } \\
\text { levels }\end{array}$ & [110] \\
\hline & $\begin{array}{l}\text { AQ extract of gel from } \\
\text { leaves }\end{array}$ & $\begin{array}{l}\text { Alcohol-induced liver toxicity in } \\
\text { rat }\end{array}$ & $1 \mathrm{~mL} / \mathrm{kg}$ & Oral & $\begin{array}{l}\downarrow \text { the elevated levels of } \\
\text { aminotransaminases, ALP, and TB and } \\
\text { maintained normal hepatocyte } \\
\text { architecture integrity }\end{array}$ & [111] \\
\hline & Fresh leaves extract & $\begin{array}{l}\text { Lindane- (LD-) induced } \\
\text { hepatotoxicity in rat }\end{array}$ & $1 \mathrm{~mL} / \mathrm{kg}$ & Oral & $\begin{array}{c}\downarrow \text { the elevated levels of SGPT, SGOT, } \\
\qquad \gamma \text {-GT, and ALP }\end{array}$ & [112] \\
\hline & Fresh AQ leaves extract & $\begin{array}{l}\text { Isoniazid- (INZ-) and rifampicin- } \\
\text { (RMP-) induced liver toxicity in } \\
\text { rats }\end{array}$ & $50 \mathrm{mg} / \mathrm{kg}$ & Oral & $\begin{array}{c}\downarrow \text { the elevated AST, ALT, ALP, acid } \\
\text { phosphatase (ACP), TB, total protein } \\
\text { (TP), total albumin (TA), and total } \\
\text { globulin (TGb) }\end{array}$ & [113] \\
\hline & Fresh AQ leaves extract & $\begin{array}{c}\mathrm{CCl}_{4} \text {-induced hepatic injury in } \\
\text { rat }\end{array}$ & $60 \mathrm{mg} / \mathrm{kg}$ & Oral & $\begin{array}{c}\downarrow \text { the elevated AST, ALT, } \gamma \text {-GT, and } \uparrow \text { the } \\
\text { liver antioxidant enzyme GSH }\end{array}$ & [114] \\
\hline & $\begin{array}{l}\text { ACTIValoe }{ }^{\circledR} \mathrm{N}-931 \\
\text { (mixture of } A . \text { vera and } \\
\text { Silybum marianum) }\end{array}$ & $\begin{array}{l}\text { CCl4-induced acute } \\
\text { hepatotoxicity in rats }\end{array}$ & $\begin{array}{l}85,170 \text {, and } \\
340 \mathrm{mg} / \mathrm{kg}\end{array}$ & IP & $\begin{array}{l}\downarrow \text { the elevated aminotransferase levels } \\
\text { and lipid peroxidation and } \uparrow \text { the liver } \\
\text { enzyme GSH, as well as } \downarrow \text { the tumor } \\
\text { necrosis factor- } \alpha \text { (TNF- } \alpha \text { ), inducible } \\
\text { nitric oxide synthase (iNOS), } \\
\text { cyclooxygenase- } 2 \text { (COX-2), and mRNA } \\
\text { expressions }\end{array}$ & [115] \\
\hline & Fresh juice & $\begin{array}{c}\text { Acute hepatitis in a } 16-65 \text { yrs of } \\
\text { age human subject (a clinical } \\
\text { diagnosis model) }\end{array}$ & $\begin{array}{l}20 \mathrm{~mL} \text { juice twice } \\
\text { daily for } 6 \text { weeks }\end{array}$ & Oral & $\downarrow$ the elevated bilirubin, ALT, and AST & [116] \\
\hline \multirow[t]{2}{*}{ A. indica } & $\begin{array}{l}\text { Hydroalcoholic extract } \\
\text { of leaves }\end{array}$ & $\begin{array}{l}\mathrm{CCl}_{4^{-}} \text {and } \mathrm{APAP} \text {-induced } \\
\text { hepatotoxicity in rats }\end{array}$ & $\begin{array}{l}250 \text { and } \\
500 \mathrm{mg} / \mathrm{kg}\end{array}$ & Oral & $\begin{array}{c}\downarrow \text { the elevated liver marker enzymes, } \\
\text { cholesterol, serum protein, and albumin } \\
\text { as well as maintained normal hepatocyte } \\
\text { architecture integrity }\end{array}$ & {$[237]$} \\
\hline & $\begin{array}{l}\text { EtOH and AQ extract } \\
\text { of tuber }\end{array}$ & $\begin{array}{c}\mathrm{CCl}_{4} \text {-induced hepatic injury in } \\
\text { rat }\end{array}$ & $200 \mathrm{mg} / \mathrm{kg}$ & Oral & $\begin{array}{c}\uparrow \text { the liver enzyme GSH, SOD, and CAT } \\
\text { as well as } \downarrow \text { the elevated ALT, AST, and } \\
\text { MDA }\end{array}$ & [238] \\
\hline A. nigra & $\mathrm{MeOH}$ extract of leaves & $\begin{array}{c}\mathrm{CCl}_{4} \text {-induced hepatic injury in } \\
\text { rat }\end{array}$ & $300 \mathrm{mg} / \mathrm{kg}$ & Oral & $\begin{array}{c}\downarrow \text { the elevated SGOT, SGPT, ALP, TB, } \\
\text { and TP }\end{array}$ & [239] \\
\hline
\end{tabular}


TABle 2: Continued.

\begin{tabular}{|c|c|c|c|c|c|c|}
\hline Plant name & $\begin{array}{l}\text { Extract and plant part } \\
\text { used }\end{array}$ & Test model & Dose & Route & Hepatoameliorative effects & Ref. \\
\hline \multirow{4}{*}{ A. spinosus } & $\begin{array}{l}50 \% \text { EtOH extract of } \\
\text { the whole plant }\end{array}$ & $\begin{array}{c}\mathrm{CCl}_{4} \text {-induced hepatic damage in } \\
\text { rat }\end{array}$ & $\begin{array}{l}\text { 100, } 200, \text { and } \\
400 \mathrm{mg} / \mathrm{kg}\end{array}$ & Oral & $\begin{array}{l}\text { Reduced oxidative stress via induction of } \\
\text { antioxidant enzymes SOD, CAT, and } \\
\text { GSH and inhibited MDA, as well as } \\
\text { restored the elevated level of serum AST, } \\
\text { ALT, ALP, and TB }\end{array}$ & {$[125]$} \\
\hline & $\mathrm{MeOH}$ extract of seeds & $\begin{array}{l}\text { Deltamethrin- (DLM-) induced } \\
\text { liver injury in rats }\end{array}$ & $15 \mathrm{mg} / \mathrm{kg}$ & Oral & $\begin{array}{c}\uparrow \text { the liver enzyme SOD, CAT, GSH, and } \\
\text { GPx and } \downarrow \text { the elevated MDA ALT, ALP, } \\
\text { and LDH }\end{array}$ & {$[240]$} \\
\hline & $\begin{array}{l}50 \% \text { EtOH extract of } \\
\text { the whole plant }\end{array}$ & $\begin{array}{l}\text { GNH2-/lipopolysaccharide- } \\
\text { induced rat liver injury }\end{array}$ & $400 \mathrm{mg} / \mathrm{kg}$ & Oral & $\begin{array}{c}\downarrow \text { the elevated ALT, AST, ALP and } \\
\gamma \text {-GTP, and serum bilirubin (SB) }\end{array}$ & [127] \\
\hline & $\begin{array}{l}\mathrm{MeOH} \text { extract of the } \\
\text { whole plant }\end{array}$ & $\begin{array}{l}\text { APAP-induced hepatotoxicity in } \\
\text { albino rats }\end{array}$ & $200 \mathrm{mg} / \mathrm{kg}$ & Oral & $\begin{array}{c}\downarrow \text { the elevated SGOT, SGPT, ALP, TB } \\
\text { and lipid peroxidation as well as } \uparrow \text { the } \\
\text { liver enzyme CAT and GSH }\end{array}$ & [126] \\
\hline \multirow{4}{*}{ A. paniculate } & $\mathrm{EtOH}$ extract of leaves & $\begin{array}{l}\text { Thioacetamide- (TAA-) induced } \\
\text { liver cirrhosis in rats }\end{array}$ & $\begin{array}{l}250 \text { and } \\
500 \mathrm{mg} / \mathrm{kg}\end{array}$ & Oral & $\begin{array}{c}\downarrow \text { the elevated ALT, AST, and ALP and } \\
\text { normalized cellular ROS level and } \\
\text { proliferation }\end{array}$ & {$[77]$} \\
\hline & EtOH extract of leaves & $\begin{array}{l}\mathrm{CCl}_{4} \text {-induced hepatic injury in } \\
\text { rat }\end{array}$ & $300 \mathrm{mg} / \mathrm{kg}$ & Oral & $\begin{array}{c}\downarrow \text { the elevated SGPT and ALP, liver } \\
\text { weight, and volume }\end{array}$ & {$[78]$} \\
\hline & AQ extract of leaves & $\begin{array}{l}\text { Hexachlorocyclohexane- (BHC-) } \\
\text { induced hepatotoxicity in mice }\end{array}$ & $12 \mathrm{mg} / \mathrm{kg}$ & Oral & $\begin{array}{l}\downarrow \text { the elevated ALT, AST, ALP and } \downarrow \text { the } \\
\text { activity of } \gamma \text {-glutamyl trans peptidase } \\
\text { ( } \gamma \text {-GTP), and lipid peroxidase (LPO) }\end{array}$ & [79] \\
\hline & EtOH extract of leaves & $\begin{array}{l}\text { APAP-induced hepatotoxicity in } \\
\text { mice }\end{array}$ & $100-200 \mathrm{mg} / \mathrm{kg}$ & Oral & $\begin{array}{c}\downarrow \text { the elevated GPT, GOT, ALP, TB, and } \\
\text { LPO, as well as } \uparrow \text { the liver enzyme SOD, } \\
\text { CAT, GSH, and GPx }\end{array}$ & {$[80]$} \\
\hline A. polystachya & EtOH leaf extracts & $\begin{array}{c}\mathrm{CCl}_{4} \text {-induced hepatic injury in } \\
\text { rat }\end{array}$ & $50 \mathrm{mg} / \mathrm{kg}$ & Oral & $\begin{array}{c}\downarrow \text { the elevated AST, ALT, ALP, ACP, and } \\
\text { LDH }\end{array}$ & [241] \\
\hline \multirow{3}{*}{ A. mexicana } & AQ extract of leaves & $\mathrm{CCl}_{4}$-induced hepatitis in rats & $250 \mathrm{mg} / \mathrm{kg}$ & Oral & $\begin{array}{l}\downarrow \text { the elevated SGOT, SGPT, ALP, and } \\
\text { direct bilirubin }\end{array}$ & [128] \\
\hline & $\begin{array}{l}\text { Leaf powder } \\
\text { suspension }\end{array}$ & $\begin{array}{c}\mathrm{CCl}_{4} \text {-induced hepatic injury in } \\
\text { rat }\end{array}$ & $\begin{array}{l}125,250, \text { and } \\
500 \mathrm{mg} / \mathrm{kg}\end{array}$ & Oral & $\begin{array}{c}\downarrow \text { the elevated AST, SGOT, ALT, SGPT, } \\
\text { ALP, TB, and direct bilirubin }\end{array}$ & [129] \\
\hline & $\begin{array}{l}\mathrm{MeOH} \text { and } \mathrm{AQ} \text { extract } \\
\text { of aerial parts }\end{array}$ & $\begin{array}{c}\mathrm{CCl}_{4} \text {-induced hepatic injury in } \\
\text { rat }\end{array}$ & $\begin{array}{c}100,200, \text { and } \\
400 \mathrm{mg} / \mathrm{kg}\end{array}$ & Oral & $\downarrow$ the elevated SGOT, SGP, and ALP & [130] \\
\hline \multirow{3}{*}{ A. racemosus } & $\begin{array}{l}\mathrm{AQ} \text { root extract and its } \\
\text { fraction }\end{array}$ & $\begin{array}{l}\mathrm{CCl}_{4} \text {-induced formation of lipid } \\
\text { peroxides in the rat liver }\end{array}$ & $300 \mathrm{mg} / \mathrm{kg}$ & Oral & $\begin{array}{l}\downarrow \text { the elevated SGPT, SGOT, ALP, TB, } \\
\text { and MDA, as well as } \uparrow \text { the liver enzyme } \\
\text { SOD, CAT, and GSH }\end{array}$ & {$[242]$} \\
\hline & Plant powder & $\begin{array}{l}\text { APAP-induced hepatotoxicity in } \\
\text { rats }\end{array}$ & $500 \mathrm{mg} / \mathrm{kg}$ & Oral & $\begin{array}{l}\downarrow \text { the elevated AST, ALT, ALP, and } \uparrow \text { the } \\
\text { liver enzyme SOD and CAT }\end{array}$ & [243] \\
\hline & NA & INZ-induced liver toxicity in rats & $50 \mathrm{mg} / \mathrm{kg}$ & Oral & $\begin{array}{c}\downarrow \text { the elevated ROS via inhibition of } \\
\text { hepatic CYP2E1 activity and } \uparrow \text { the liver } \\
\text { enzyme GSH }\end{array}$ & [244] \\
\hline \multirow{3}{*}{ A. carambola } & AQ fruit extract & $\begin{array}{l}\text { CCl4-induced hepatic injury in } \\
\text { mice }\end{array}$ & $0.9 \mathrm{~g} / \mathrm{kg}$ & Oral & $\begin{array}{l}\downarrow \text { the elevated ALT, AST, ALP, and } \uparrow \text { the } \\
\text { liver enzyme GSH }\end{array}$ & [245] \\
\hline & EtOH extract of fruits & $\begin{array}{l}\text { Chemically induced } \\
\text { hepatocellular carcinoma in mice }\end{array}$ & $\begin{array}{l}05,15,25,50 \\
\text { and } 75 \mathrm{mg} / \mathrm{kg}\end{array}$ & Oral & $\begin{array}{l}\downarrow \text { the tumor incidence, tumor yield, } \\
\text { tumor burden, and LPO, as well as } \uparrow \text { the } \\
\text { liver enzyme SOD and CAT }\end{array}$ & [246] \\
\hline & $\begin{array}{l}\mathrm{MeOH} \text { extracts of ripe } \\
\text { fruits }\end{array}$ & $\begin{array}{l}\text { APAP- and D-galactosamine- } \\
\text { induced hepatotoxicity in rats }\end{array}$ & $100 \mathrm{mg} / \mathrm{kg}$ & Oral & $\downarrow$ the elevated SGOT, SGPT, and TB & {$[94]$} \\
\hline \multirow{6}{*}{ B. montanum } & $\mathrm{MeOH}$ extract of root & TAA-induced liver toxicity in rats & $\begin{array}{l}100,200, \text { and } \\
300 \mathrm{mg} / \mathrm{kg}\end{array}$ & Oral & $\begin{array}{c}\downarrow \text { the elevated GOT, SGPT, ALP, TB, TG, } \\
\text { TP, and albumin }\end{array}$ & [34] \\
\hline & $\begin{array}{l}\text { EtOH and AQ root } \\
\text { extract }\end{array}$ & $\begin{array}{l}\text { APAP-induced liver toxicity in } \\
\text { rats }\end{array}$ & $100-2000 \mathrm{mg} / \mathrm{kg}$ & Oral & $\begin{array}{c}\downarrow \text { the elevated oxidative stress and GPT, } \\
\text { GOT, and ALP }\end{array}$ & [35] \\
\hline & \multirow{2}{*}{$\begin{array}{l}\mathrm{MeOH} \text { and ethylmetyl } \\
\text { ketone subfraction of } \\
\text { root }\end{array}$} & $\begin{array}{l}\mathrm{CCl}_{4} \text {-induced hepatotoxicity in } \\
\text { rats }\end{array}$ & $\begin{array}{l}50,100, \text { and } \\
150 \mathrm{mg} / \mathrm{kg}\end{array}$ & Oral & $\downarrow$ the elevated GOT, GPT, and TP & \multirow{2}{*}{ [36] } \\
\hline & & In vitro hepatocyte viability & $\begin{array}{c}100,500, \text { and } \\
1000 \mu \mathrm{g} / \mathrm{mL}\end{array}$ & $\begin{array}{l}\text { Cell } \\
\text { culture }\end{array}$ & $\uparrow$ the viability of hepatocyte & \\
\hline & \multirow{2}{*}{$\begin{array}{l}\mathrm{MeOH} \text { subfraction of } \\
\text { root }\end{array}$} & $\begin{array}{l}\text { APAP-induced hepatotoxicity in } \\
\text { rats }\end{array}$ & $\begin{array}{l}50,100, \text { and } \\
150 \mathrm{mg} / \mathrm{kg}\end{array}$ & Oral & $\begin{array}{c}\downarrow \text { the elevated oxidative stress and GPT, } \\
\text { GOT, and TP }\end{array}$ & \multirow{2}{*}{ [37] } \\
\hline & & In vitro hepatocyte viability & $\begin{array}{l}100,500, \text { and } \\
1000 \mu \mathrm{g} / \mathrm{mL}\end{array}$ & $\begin{array}{c}\text { Cell } \\
\text { culture }\end{array}$ & $\begin{array}{c}\uparrow \text { the viability of hepatocyte and } \downarrow \text { the } \\
\text { elevated level of cellular TP }\end{array}$ & \\
\hline
\end{tabular}


TABle 2: Continued.

\begin{tabular}{|c|c|c|c|c|c|c|}
\hline Plant name & $\begin{array}{c}\text { Extract and plant part } \\
\text { used }\end{array}$ & Test model & Dose & Route & Hepatoameliorative effects & Ref. \\
\hline \multirow{4}{*}{ B. orellana } & $\begin{array}{l}\text { MeOH extract of aerial } \\
\text { parts }\end{array}$ & $\begin{array}{c}\text { CCl4-induced hepatic injury in } \\
\text { rats }\end{array}$ & $500 \mathrm{mg} / \mathrm{kg}$ & Oral & $\begin{array}{c}\downarrow \text { the elevated ALT, SGPT, AST, SGOT, } \\
\text { and cholesterol }\end{array}$ & [95] \\
\hline & Seed oil & $\begin{array}{c}\text { CCl4-induced hepatic injury in } \\
\text { rats }\end{array}$ & $0,1,5$, and $10 \%$ & Oral & $\begin{array}{c}\downarrow \text { the elevated liver biomarker enzymes, } \\
\text { TB, and LPO }\end{array}$ & [132] \\
\hline & $\begin{array}{l}\text { Petroleum ether (PE), } \\
\mathrm{MeOH} \text {, and AQ leaves } \\
\text { extracts }\end{array}$ & $\begin{array}{l}\text { CCl4-induced hepatic injury in } \\
\text { rats }\end{array}$ & $\begin{array}{l}250,500,750 \text {, } \\
\text { and } 1000 \mathrm{mg} / \mathrm{kg}\end{array}$ & Oral & $\begin{array}{c}\downarrow \text { the elevated TB, direct bilirubin, ALT, } \\
\text { AST, ALP, and TP }\end{array}$ & [131] \\
\hline & $\begin{array}{l}50 \% \text { EtOH extract of } \\
\text { seeds }\end{array}$ & $\begin{array}{l}\text { Ethanol-induced acute } \\
\text { hepatotoxicity in rats }\end{array}$ & $\begin{array}{c}200 \text { and } \\
400 \mathrm{mg} / \mathrm{kg}\end{array}$ & Oral & $\begin{array}{c}\downarrow \text { the elevated AST, ALT, ALP, TB, and } \\
\text { LDH }\end{array}$ & [133] \\
\hline \multirow{5}{*}{ B. diffusa } & AQ extract of root & $\begin{array}{l}\text { TAA-induced hepatotoxicity in } \\
\text { rats }\end{array}$ & $2 \mathrm{~mL} / \mathrm{kg}$ & Oral & $\begin{array}{l}\downarrow \text { the elevated GOT, GPT, ACP, and } \\
\text { ALP, but not LDH and bilirubin }\end{array}$ & [247] \\
\hline & EtOH extract of root & $\begin{array}{l}\text { Ethanol-induced liver damage in } \\
\text { rats }\end{array}$ & $150 \mathrm{mg} / \mathrm{kg}$ & Oral & $\begin{array}{c}\downarrow \text { the elevated AST, ALT, ALP, LDH, and } \\
\quad \gamma \text {-GTP to the normal level }\end{array}$ & [248] \\
\hline & $\begin{array}{l}\mathrm{MeOH}(85 \%) \text { extract of } \\
\text { root and the aerial part }\end{array}$ & $\begin{array}{l}\text { Ibuprofen- (IB-) induced } \\
\text { hepatotoxicity in rats }\end{array}$ & $500 \mathrm{mg} / \mathrm{kg}$ & Oral & $\begin{array}{c}\downarrow \text { the elevated ALT, AST, ALP, and TB } \\
\text { and } \uparrow \text { the liver enzyme SOD, CAT, GPx, } \\
\text { and GST, as well as normalized liver } \\
\text { histological changes }\end{array}$ & [134] \\
\hline & $\begin{array}{l}\text { EtOH extract of the } \\
\text { whole plant }\end{array}$ & $\begin{array}{c}\mathrm{CCl}_{4} \text {-induced hepatotoxicity in } \\
\text { mice }\end{array}$ & $\begin{array}{l}100,200, \text { and } \\
300 \mathrm{mg} / \mathrm{kg}\end{array}$ & Oral & $\begin{array}{c}\downarrow \text { the elevated ALT, AST, ALP, ACP, } \\
\text { LDH, } \gamma \text {-GT, and TB and inhibit LOP, as } \\
\text { well as normalized liver histological } \\
\text { changes }\end{array}$ & [136] \\
\hline & $\begin{array}{l}\text { EtOH }(50 \%) \text { extract of } \\
\text { the whole plant }\end{array}$ & $\begin{array}{c}\mathrm{CCl}_{4} \text {-induced hepatotoxicity in } \\
\text { rats }\end{array}$ & $2000 \mathrm{mg} / \mathrm{kg}$ & Oral & $\begin{array}{l}\text { Protective activity via protection of } \\
\text { drug-metabolizing enzymes and } \downarrow \text { the } \\
\text { elevated SGOP and SGPT as well as } \\
\text { increased bile flow to the liver }\end{array}$ & [135] \\
\hline \multirow{4}{*}{ C. cajan } & $\begin{array}{l}\text { MeOH extract of aerial } \\
\text { parts }\end{array}$ & $\mathrm{CCl}_{4}$-induced liver injury in rats & $500 \mathrm{mg} / \mathrm{kg}$ & Oral & $\begin{array}{c}\downarrow \text { the elevated ALT, SGPT, AST, SGOT, } \\
\text { and cholesterol }\end{array}$ & [95] \\
\hline & EtOH extract of leaves & $\begin{array}{l}\text { D-galactosamine-induced } \\
\text { hepatitis in rats }\end{array}$ & $100 \mathrm{mg} / \mathrm{kg}$ & Oral & $\begin{array}{l}\uparrow \text { the liver enzyme CAT, SOD, GPx, and } \\
\text { GST and } \downarrow \text { the elevated AST and ALT }\end{array}$ & [96] \\
\hline & $\begin{array}{l}\text { MeOH-AQ fraction of } \\
\text { leaves }\end{array}$ & Alcohol-induced rat liver damage & $50 \mathrm{mg} / \mathrm{kg}$ & Oral & $\begin{array}{l}\downarrow \text { the elevated liver marker enzymes and } \\
\uparrow \text { the liver enzyme activities. Molecular } \\
\text { mechanism involved the upregulation of } \\
\text { UDP-glucuronosyl transferase-2B } \\
\text { (UGT2B) expression and activation of } \\
\text { Nrf2 }\end{array}$ & [97] \\
\hline & $\begin{array}{l}\mathrm{MeOH} \text { extract of } \\
\text { tender leaves }\end{array}$ & $\begin{array}{l}\text { APAP and D-galactosamine } \\
\text { induced hepatic injury in rats }\end{array}$ & $100 \mathrm{mg} / \mathrm{kg}$ & Oral & $\downarrow$ the elevated SGOT, SGPT, and TB & [94] \\
\hline C. floribunda & $\begin{array}{l}\mathrm{CHCl}_{3} \text { fraction of } \\
\mathrm{MeOH} \text { extract of stem }\end{array}$ & $\begin{array}{l}\text { CCl4-induced hepatotoxicity in } \\
\text { rats }\end{array}$ & $\begin{array}{l}100 \mathrm{and} \\
200 \mathrm{mg} / \mathrm{kg}\end{array}$ & Oral & $\begin{array}{l}\downarrow \text { the elevated SGOT, SGPT, ALP, and } \\
\text { TB, as well as cellular protection of } \\
\text { centribular necrosis and vacuolization }\end{array}$ & [249] \\
\hline \multirow{3}{*}{ C. tinctorius } & Seed oil & $\begin{array}{c}\text { Alloxan-induced liver toxicity in } \\
\text { type } 1 \text { diabetic rats }\end{array}$ & $200 \mathrm{mg} / \mathrm{kg}$ & Oral & $\begin{array}{l}\downarrow \text { the elevated blood glucose, TC, TGs, } \\
\text { LDL, ALT, AST, and ALP and increased } \\
\text { the level of HDL }\end{array}$ & {$[61]$} \\
\hline & $\begin{array}{l}\mathrm{MeOH} \text { extract of } \\
\text { flowers }\end{array}$ & CCl4-induced liver injury in rats & $200 \mathrm{mg} / \mathrm{kg}$ & Oral & $\begin{array}{l}\downarrow \text { the elevated ALT, ALP, AST, MDA, } \\
\text { TB, and inflammatory cytokines (TNF- } \alpha \\
\text { and IL-6), as well as } \uparrow \text { the liver enzyme } \\
\text { SOD, CAT, and GSH }\end{array}$ & {$[60]$} \\
\hline & $\mathrm{MeOH}$ extract of leaves & $\mathrm{CCl}_{4}$-induced liver toxicity in rats & $\begin{array}{c}150 \text { and } \\
300 \mathrm{mg} / \mathrm{kg}\end{array}$ & Oral & $\downarrow$ the elevated blood ALT, AST, and ALP & {$[62]$} \\
\hline \multirow{7}{*}{ C. fistula } & EtOH leaf extract & $\begin{array}{l}\text { Diethyl nitrosamine- (DEN-) } \\
\text { induced liver toxicity in rats }\end{array}$ & $500 \mathrm{mg} / \mathrm{kg}$ & Oral & $\begin{array}{l}\uparrow \text { the liver enzyme SOD and CAT and } \uparrow \\
\text { the liver enzyme LPO, AST, ALT, ALP, } \\
\text { LDH, } \gamma-\text { GT, and TB }\end{array}$ & [103] \\
\hline & $\begin{array}{c}\text { n-Heptane extract of } \\
\text { leaves }\end{array}$ & $\begin{array}{l}\text { APAP-induced hepatotoxicity in } \\
\text { rats }\end{array}$ & $400 \mathrm{mg} / \mathrm{kg}$ & Oral & $\downarrow$ the elevated SGOT, SGPT, TB and ALP & [98] \\
\hline & $\begin{array}{c}\text { n-Heptane extract of } \\
\text { leaves }\end{array}$ & $\begin{array}{l}\text { CCl4 with liquid paraffin }(1: 1) \text { - } \\
\text { induced liver injury in rats }\end{array}$ & $400 \mathrm{mg} / \mathrm{kg}$ & Oral & $\begin{array}{c}\downarrow \text { the elevated SGOT, SGPT, TB, and } \\
\text { ALP }\end{array}$ & [99] \\
\hline & $\begin{array}{l}\text { Hydroalcoholic extract } \\
\text { of fruit }\end{array}$ & $\begin{array}{c}\text { Bromobenzene-induced liver } \\
\text { toxicity in mice }\end{array}$ & $\begin{array}{l}200,400,600 \text {, } \\
\text { and } 800 \mathrm{mg} / \mathrm{kg}\end{array}$ & Oral & $\begin{array}{c}\text { Dose-dependently } \downarrow \text { the elevated AST, } \\
\text { ALT, ALP, and TB }\end{array}$ & [101] \\
\hline & AQ extract of fruit pulp & CCl4-induced liver injury in rats & $200 \mathrm{mg} / \mathrm{kg}$ & Oral & $\begin{array}{c}\downarrow \text { the elevated AST, ALT, ALP, and TB } \\
\text { and increase in TP }\end{array}$ & [102] \\
\hline & $\mathrm{MeOH}$ extract of seeds & APAP-induced hepatitis in rats & $\begin{array}{l}200 \text { and } \\
400 \mathrm{mg} / \mathrm{kg}\end{array}$ & Oral & $\begin{array}{c}\downarrow \text { the elevated SGOT, SGPT, ALP, and } \\
\text { TB to the normal levels }\end{array}$ & {$[100]$} \\
\hline & EtOH extract of leaves & $\begin{array}{l}\text { INZ- and RIF-induced liver } \\
\text { toxicity in rats }\end{array}$ & $\begin{array}{l}400 \mathrm{and} \\
500 \mathrm{mg} / \mathrm{kg}\end{array}$ & Oral & $\begin{array}{c}\downarrow \text { the elevated oxidative stress and ALT, } \\
\text { AST, ALP, and TB }\end{array}$ & [104] \\
\hline
\end{tabular}


TABle 2: Continued.

\begin{tabular}{|c|c|c|c|c|c|c|}
\hline Plant name & $\begin{array}{c}\text { Extract and plant part } \\
\text { used }\end{array}$ & Test model & Dose & Route & Hepatoameliorative effects & Ref. \\
\hline \multirow{5}{*}{ C. bonducella } & AQ extract of leaves & $\begin{array}{l}\mathrm{CCl}_{4} \text {-induced chronic rat } \\
\text { hepatotoxicity }\end{array}$ & NA & Oral & $\begin{array}{c}\downarrow \text { the elevated ALT, AST, ALP, TB, and } \\
\text { prothrombin time (PT) }\end{array}$ & {$[107]$} \\
\hline & EtOH extract of leaves & $\begin{array}{c}\mathrm{CCl}_{4} \text {-induced hepatotoxicity in } \\
\text { rat }\end{array}$ & $\begin{array}{l}250 \text { and } \\
500 \mathrm{mg} / \mathrm{kg}\end{array}$ & Oral & $\begin{array}{c}\downarrow \text { the elevated AST, ALT, ALP, TB, and } \\
\text { MDA with an } \uparrow \text { the liver enzyme CAT } \\
\text { and GPx }\end{array}$ & [105] \\
\hline & $\mathrm{MeOH}$ leaf extract & $\begin{array}{l}\text { Gentamicin-induced rat liver } \\
\text { toxicity }\end{array}$ & $\begin{array}{l}250 \text { and } \\
500 \mathrm{mg} / \mathrm{kg}\end{array}$ & Oral & $\begin{array}{c}\uparrow \text { the liver enzyme ALT, AST, ALP, TB, } \\
\text { and TP }\end{array}$ & [106] \\
\hline & $\mathrm{MeOH}$ extract of leaves & $\begin{array}{l}\mathrm{CCl}_{4} \text {-induced chronic rat } \\
\text { hepatotoxicity }\end{array}$ & $\begin{array}{l}50,100 \text {, and } \\
200 \mathrm{mg} / \mathrm{kg}\end{array}$ & Oral & $\begin{array}{c}\uparrow \text { the liver enzyme SGPT, SGOT, ALP, } \\
\text { TB, uric acid, and LPO whereas reduced } \\
\text { oxidative stress via } \uparrow \text { the liver enzyme } \\
\text { SOD, CAT, GSH, vit. C, vit.E, and } \\
\text { protein }\end{array}$ & [109] \\
\hline & $\mathrm{MeOH}$ extract of leaves & $\begin{array}{l}\text { APAP-induced liver damage in } \\
\text { rats }\end{array}$ & $\begin{array}{l}\text { 50, } 100 \text {, and } \\
200 \mathrm{mg} / \mathrm{kg}\end{array}$ & Oral & $\begin{array}{l}\downarrow \text { the elevated liver marker enzymes, } \\
\text { bilirubin, and LPO, as well as } \uparrow \text { the liver } \\
\text { enzyme GSH, SOD, CAT, and protein }\end{array}$ & [108] \\
\hline \multirow{5}{*}{ C. papaya } & $\mathrm{MeOH}$ extract of stalk & $\begin{array}{l}\text { CCl4-induced liver damage in } \\
\text { rats }\end{array}$ & $\begin{array}{l}20,40,60,80 \\
\text { and } 100 \mathrm{mg} / \mathrm{kg}\end{array}$ & Oral & $\downarrow$ the elevated TP, AST, and ALT & [138] \\
\hline & $\mathrm{AQ}$ extract of ripe seed & $\begin{array}{c}\text { CCl4-induced hepatotoxicity in } \\
\text { rats }\end{array}$ & $\begin{array}{l}100,200, \text { and } \\
300 \mathrm{mg} / \mathrm{kg}\end{array}$ & Oral & $\begin{array}{c}\downarrow \text { the elevated ALT, AST, ALP, and } \\
\text { bilirubin }\end{array}$ & [139] \\
\hline & $\begin{array}{l}\text { AQ extract of leaf and } \\
\text { unripe fruits }\end{array}$ & $\begin{array}{l}\text { CCl4- and APAP-induced } \\
\text { hepatotoxicity in rats }\end{array}$ & $\begin{array}{c}100 \mathrm{and} \\
300 \mathrm{mg} / \mathrm{kg}\end{array}$ & Oral & $\begin{array}{c}\uparrow \text { the liver enzyme GSH, SOD, and CAT, } \\
\text { as well as } \downarrow \text { the elevated AST, ALT, ALP, } \\
\text { LDH, and MDA }\end{array}$ & [137] \\
\hline & $\begin{array}{l}\text { AQ seed extract of } \\
\text { unripe fruit }\end{array}$ & $\begin{array}{l}\text { CCl4-induced hepatotoxicity in } \\
\text { rats }\end{array}$ & $100-400 \mathrm{mg} / \mathrm{kg}$ & Oral & $\begin{array}{c}\downarrow \text { the elevated liver marker enzyme (ALT } \\
\text { and AST), serum lipids (TG, TC, HDL-c, } \\
\text { LDL-c, and VLDL-c), and serum } \\
\text { proteins (TP and ALB) }\end{array}$ & [141] \\
\hline & $\begin{array}{l}\mathrm{AQ} \text { and EtOH extracts } \\
\text { of dried fruit }\end{array}$ & $\begin{array}{l}\text { CCl4-induced hepatotoxicity in } \\
\text { rats }\end{array}$ & $250 \mathrm{mg} / \mathrm{kg}$ & Oral & $\downarrow$ the elevated ALT, AST, and ALP & [140] \\
\hline \multirow{4}{*}{ C. album } & EtOH extract of leaves & $\begin{array}{c}\text { EtOH-induced hepatotoxicity in } \\
\text { rat }\end{array}$ & $\begin{array}{l}100,200, \text { and } \\
400 \mathrm{mg} / \mathrm{kg}\end{array}$ & Oral & $\begin{array}{c}\downarrow \text { the elevated liver marker enzymes and } \\
\text { LPO, as well as } \uparrow \text { the liver enzyme GSH, } \\
\text { SOD, and CAT }\end{array}$ & [250] \\
\hline & AQ extract of leaves & CCl4-induced liver fibrosis in rats & $\begin{array}{l}100,200 \text {, and } \\
400 \mathrm{mg} / \mathrm{kg}\end{array}$ & Oral & $\begin{array}{c}\downarrow \text { the elevated SGPT, SGOT, ALP, LDH, } \\
\text { TC, and TB }\end{array}$ & [251] \\
\hline & EtOH extract of leaves & $\begin{array}{c}\text { EtOH-induced hepatotoxicity in } \\
\text { rat }\end{array}$ & $\begin{array}{l}200,400, \text { and } \\
600 \mathrm{mg} / \mathrm{kg}\end{array}$ & Oral & $\begin{array}{l}\downarrow \text { the elevated AST, SGOT, ALT or } \\
\text { SGPT, ALP, TB, TC, and LPO and } \uparrow \text { the } \\
\text { liver enzyme SOD, CAT, and GSH }\end{array}$ & [252] \\
\hline & $\begin{array}{l}\text { Alcoholic and AQ } \\
\text { extracts of the aerial }\end{array}$ & $\begin{array}{l}\text { APAP-induced hepatotoxicity in } \\
\text { rats }\end{array}$ & $\begin{array}{c}200 \mathrm{and} \\
400 \mathrm{mg} / \mathrm{kg}\end{array}$ & Oral & $\begin{array}{l}\downarrow \text { the elevated transaminases, alkaline } \\
\text { phosphatase, and bilirubin content }\end{array}$ & [253] \\
\hline \multirow{6}{*}{ C. colocynthis } & $\mathrm{MeOH}$ extract of fruits & $\begin{array}{l}\text { APAP-induced hepatotoxicity in } \\
\text { rat }\end{array}$ & $300 \mathrm{mg} / \mathrm{kg}$ & Oral & $\begin{array}{l}\downarrow \text { oxidative stress via the antioxidant } \\
\text { mechanism and } \downarrow \text { the elevated TB, } \\
\text { SGOT, SGPT, and ALP }\end{array}$ & [40] \\
\hline & EtOH fruit extract & $\begin{array}{l}\text { Cisplatin-induced hepatorenal } \\
\text { toxicity in rats }\end{array}$ & $\begin{array}{l}100,200 \text {, and } \\
400 \mathrm{mg} / \mathrm{kg}\end{array}$ & Oral & $\begin{array}{c}\downarrow \text { the elevated MDA and nitrite levels, as } \\
\text { well as } \uparrow \text { the liver enzyme GSH, CAT, } \\
\text { and SOD }\end{array}$ & [42] \\
\hline & $\begin{array}{l}\text { Hydroalcoholic fruit } \\
\text { extract and its } \\
\text { subfraction }\end{array}$ & $\begin{array}{c}\mathrm{CCl}_{4} \text {-induced and } \\
\text { lipopolysaccharide-induced } \\
\text { hepatotoxicity in mice }\end{array}$ & $400 \mathrm{mg} / \mathrm{kg}$ & Oral & $\downarrow$ the elevated AST and ALT & [43] \\
\hline & EtOH extract of roots & $\begin{array}{c}\mathrm{CCl}_{4} \text {-induced hepatic toxicity in } \\
\text { rats }\end{array}$ & $100 \mathrm{mg} / \mathrm{kg}$ & Oral & $\begin{array}{c}\downarrow \text { the elevated GPT, GOT, ALP, and } \\
\text { bilirubin }\end{array}$ & [45] \\
\hline & EtOH fruit extract & $\begin{array}{l}\text { Polluted water-induced hepatic } \\
\text { damage in rats }\end{array}$ & $\begin{array}{c}100 \text { and } \\
200 \mathrm{mg} / \mathrm{kg}\end{array}$ & Oral & $\begin{array}{c}\downarrow \text { the elevated AST, ALT, ALP, TP, and } \\
\text { bilirubin }\end{array}$ & [44] \\
\hline & EtOH fruit extract & $\begin{array}{l}\text { APAP-induced hepatic injury in } \\
\text { rats }\end{array}$ & $\begin{array}{l}\text { 50, 100, and } \\
200 \mathrm{mg} / \mathrm{kg}\end{array}$ & Oral & $\begin{array}{c}\uparrow \text { cell membrane stabilization, hepatic } \\
\text { cell regeneration and } \downarrow \text { the elevated AST, } \\
\text { ALT, and ALP }\end{array}$ & [41] \\
\hline
\end{tabular}


TABle 2: Continued.

\begin{tabular}{|c|c|c|c|c|c|c|}
\hline Plant name & $\begin{array}{l}\text { Extract and plant part } \\
\text { used }\end{array}$ & Test model & Dose & Route & Hepatoameliorative effects & Ref. \\
\hline \multirow{5}{*}{ C. lanatus } & $\begin{array}{l}\text { Aqueous EtOH seed } \\
\text { extract }\end{array}$ & $\begin{array}{l}\mathrm{CCl}_{4} \text {-induced hepatic fibrosis in } \\
\text { mice }\end{array}$ & $\begin{array}{l}100,200,400, \\
\text { and } 800 \mathrm{mg} / \mathrm{kg}\end{array}$ & Oral & $\begin{array}{l}\text { Improving drug metabolizing enzyme } \\
\text { activity, } \downarrow \text { the elevated AST, ALT, HA, } \\
\text { and LN, as well as } \uparrow \text { the liver enzyme } \\
\text { SOD and GP. Molecular mechanism } \\
\text { involved the inhibition of } \alpha \text {-SMA and } \\
\text { TGF- } \beta 1 \text { protein expression }\end{array}$ & [47] \\
\hline & Juice of pulp & $\begin{array}{l}\text { Ethanol-induced hepatic } \\
\text { oxidative stress in rats }\end{array}$ & $4 \mathrm{~mL} / \mathrm{kg}$ & Oral & $\begin{array}{c}\downarrow \text { the elevated MDA and } \uparrow \text { the liver } \\
\text { enzyme CAT }\end{array}$ & [46] \\
\hline & EtOH leaf extract & $\begin{array}{l}\text { CCl4-induced hepatic toxicity in } \\
\text { rats }\end{array}$ & $\begin{array}{l}500,1,000, \text { and } \\
1,500 \mathrm{mg} / \mathrm{kg}\end{array}$ & Oral & $\begin{array}{c}\downarrow \text { congestion and necrosis, as well as } \downarrow \\
\text { the elevated AST, ALT, ALP, and } \\
\text { bilirubin }\end{array}$ & {$[50]$} \\
\hline & $\mathrm{MeOH}$ seed extract & APAP-induced liver injury in rats & $\begin{array}{l}200 \text { and } \\
400 \mathrm{mg} / \mathrm{kg}\end{array}$ & Oral & $\begin{array}{l}\downarrow \text { the elevated AST, ALT, ALP, and } \\
\text { bilirubin }\end{array}$ & {$[48]$} \\
\hline & $\begin{array}{l}\mathrm{AQ} \text { and } \mathrm{MeOH} \\
\text { extracts of seeds }\end{array}$ & $\begin{array}{l}\text { Salt- and APAP-induced hepatic } \\
\text { toxicity in female rats }\end{array}$ & $\begin{array}{l}200 \mathrm{and} \\
400 \mathrm{mg} / \mathrm{kg}\end{array}$ & Oral & $\begin{array}{l}\text { Exerts antioxidant effects and healing } \\
\text { with rejuvenating effects on the liver, as } \\
\text { well as protects hepatocytes }\end{array}$ & [49] \\
\hline C. orchioides & $\begin{array}{l}\mathrm{MeOH} \text { extract of } \\
\text { rhizome }\end{array}$ & $\begin{array}{l}\text { CCl4-induced hepatopathy in } \\
\text { rats }\end{array}$ & $70 \mathrm{mg} / \mathrm{kg}$ & Oral & $\begin{array}{l}\uparrow \text { the liver enzyme SOD, CAT, GPx, and } \\
\text { GR }\end{array}$ & [254] \\
\hline \multirow{6}{*}{ C. longa } & $\begin{array}{l}\text { Crude extract of } \\
\text { rhizome }\end{array}$ & $\begin{array}{c}\text { INZ-RIF-pyzinamide (PZA)- } \\
\text { induced hepatic injury in Guinea } \\
\text { pigs }\end{array}$ & $200 \mathrm{mg} / \mathrm{kg}$ & Oral & $\begin{array}{l}\downarrow \text { the elevated AST, ALT, and normalized } \\
\text { liver histological changes }\end{array}$ & {$[120]$} \\
\hline & $\begin{array}{l}\mathrm{MeOH} \text { extract of } \\
\text { rhizome }\end{array}$ & $\begin{array}{l}\text { D-galactosamine- (GNH2-) } \\
\text { induced liver injury in mice }\end{array}$ & $100 \mathrm{mg} / \mathrm{kg}$ & Oral & $\begin{array}{c}\uparrow \text { the liver enzyme SOD, glutathione-s- } \\
\text { transferase (GST), CAT and SOD, and } \\
\text { GSH with a } \downarrow \text { in the elevated LPO, AST, } \\
\text { ALT, and ALP }\end{array}$ & [121] \\
\hline & $\begin{array}{l}\mathrm{MeOH} \text { extract of } \\
\text { rhizome }\end{array}$ & $\begin{array}{l}\text { Alloxan-induced liver injury in } \\
\text { rabbits }\end{array}$ & $2000 \mathrm{mg} / \mathrm{kg}$ & Oral & $\begin{array}{l}\text { Improves the levels of serum glucose, } \\
\text { serum transaminases and antioxidant } \\
\text { activity }\end{array}$ & [124] \\
\hline & $\begin{array}{l}\text { EtOH extract of } \\
\text { rhizome }\end{array}$ & $\begin{array}{l}\text { TAA-induced liver cirrhosis in } \\
\text { rats }\end{array}$ & $\begin{array}{l}250 \text { and } \\
500 \mathrm{mg} / \mathrm{kg}\end{array}$ & Oral & $\begin{array}{c}\downarrow \text { the elevated MDA, AST, ALT, ALP, } \\
\text { nitrotyrosine, and urinary } 8 \text { - } \\
\text { hydroxyguanosine and } \uparrow \text { the liver } \\
\text { enzyme SOD and CAT, as well as } \\
\text { restored the elevated cytokines TGF- } \beta 1 \text {, } \\
\text { TNF- } \alpha \text {, and induction of apoptosis }\end{array}$ & [119] \\
\hline & $\begin{array}{l}\text { EtOH extract of } \\
\text { rhizome }\end{array}$ & $\begin{array}{l}\text { Mercuric chloride-induced } \\
\text { hepatotoxicity and oxidative } \\
\text { stress in rat }\end{array}$ & $200 \mathrm{mg} / \mathrm{kg}$ & Oral & $\begin{array}{l}\downarrow \text { the elevated transaminase, ALP, LDH, } \\
\text { TB, } \gamma \text {-GT, and TG, as well as a protective } \\
\text { effect on drug metabolizing CYP 2E1 } \\
\text { enzymes, viz., aniline hydroxylase (AH) } \\
\text { and amidopyrine-N-demethylase } \\
\text { (AND) }\end{array}$ & [123] \\
\hline & $\begin{array}{l}50 \% \text { EtOH extract of } \\
\text { rhizome }\end{array}$ & $\begin{array}{c}\mathrm{CCl}_{4} \text {-induced acute hepatic stress } \\
\text { in rat }\end{array}$ & $\begin{array}{l}100,200 \text {, and } \\
300 \mathrm{mg} / \mathrm{kg}\end{array}$ & Oral & $\begin{array}{c}\downarrow \text { the elevated ALT, AST and ALP, and } \\
\text { LPO }\end{array}$ & [122] \\
\hline C. reflexa & AQ extracts & $\begin{array}{c}\mathrm{CHCl}_{3^{-}}, \mathrm{EtOH}-\text {, and APAP- } \\
\text { induced hepatotoxic rat }\end{array}$ & $\begin{array}{l}50,100 \text {, and } \\
200 \mathrm{mg} / \mathrm{kg}\end{array}$ & Oral & $\begin{array}{l}\downarrow \text { the elevated SGOT, SGPT, and ALP } \\
\text { restore to the normal level }\end{array}$ & [255] \\
\hline C. melo & $\mathrm{MeOH}$ extract fruit & $\begin{array}{l}\text { RIF-INZ induced hepatotoxicity } \\
\text { in rat }\end{array}$ & $\begin{array}{l}100,250 \text {, and } \\
500 \mathrm{mg} / \mathrm{kg}\end{array}$ & IP & $\begin{array}{l}\downarrow \text { the elevated ALT, AST, ALP, LPO, TB, } \\
\text { and TP, as well as } \uparrow \text { the liver enzyme } \\
\text { GPx, GRD, SOD, CAT, and GSH }\end{array}$ & [256] \\
\hline C. ternatea & $\mathrm{MeOH}$ extract of leaf & $\begin{array}{l}\text { APAP-induced liver injury in } \\
\text { mice }\end{array}$ & $200 \mathrm{mg} / \mathrm{kg}$ & Oral & $\downarrow$ the elevated ALT, AST, and TB & [257] \\
\hline \multirow{4}{*}{ D. carota } & $\begin{array}{l}\text { Oil extract and its } \\
\text { fraction of tuber root }\end{array}$ & $\begin{array}{l}\mathrm{CCl}_{4} \text {-induced hepatotoxicity in } \\
\text { rats }\end{array}$ & $\begin{array}{l}\text { 50, } 100 \text {, and } \\
200 \mathrm{mg} / \mathrm{kg}\end{array}$ & IP & $\begin{array}{l}\uparrow \text { the liver enzyme SOD, CAT, and GST, } \\
\text { as well as } \downarrow \text { the elevated AST and ALP }\end{array}$ & [144] \\
\hline & $\begin{array}{l}\text { AQ extract of tuber } \\
\text { roots }\end{array}$ & $\begin{array}{l}\text { APAP-, INZ-, and EtOH-induced } \\
\text { liver injury in rats }\end{array}$ & $25 \mathrm{~mL} / \mathrm{kg}$ & Oral & $\downarrow$ the elevated AST, ALT, TB, and PT & [142] \\
\hline & $\begin{array}{l}\text { AQ extract of tuber } \\
\text { roots }\end{array}$ & $\begin{array}{l}\text { LD-induced hepatotoxicity in } \\
\text { rats }\end{array}$ & $25 \mathrm{~mL} / \mathrm{kg}$ & Oral & $\begin{array}{l}\downarrow \text { the elevated AST, ALT, ALP, } \\
\text { thiobarbituric acid reactive substances, } \\
\text { TC, TG, and LDL-cholesterol. It also } \\
\text { restored the depressed antioxidant. }\end{array}$ & [143] \\
\hline & $\mathrm{MeOH}$ extract of seeds & TAA-induced liver toxicity in rats & $\begin{array}{l}200 \text { and } \\
400 \mathrm{mg} / \mathrm{kg}\end{array}$ & Oral & $\begin{array}{l}\uparrow \text { the liver enzyme SOD, CAT, GPx, } \\
\text { GST, and GR and } \downarrow \text { the elevated LPO, } \\
\text { SGPT, SGOT, and ALP }\end{array}$ & [258] \\
\hline \multirow[b]{2}{*}{ E. viride } & EtOH extract of roots & APAP-induced liver injury in rat & $200,400 \mathrm{mg} / \mathrm{kg}$ & Oral & $\begin{array}{c}\downarrow \text { the elevated SGPT, SGOT, ALP, TB } \\
\text { and TG }\end{array}$ & [259] \\
\hline & $\begin{array}{l}\mathrm{MeOH} \text { extract of whole } \\
\text { plant }\end{array}$ & $\begin{array}{l}\mathrm{CCl}_{4^{-}} \text {and APAP-induced } \\
\text { hepatotoxicity in rats }\end{array}$ & $300 \mathrm{mg} / \mathrm{kg}$ & Oral & $\begin{array}{c}\downarrow \text { the elevated SGOT, SGPT, ALP, and } \\
\text { TB, as well as } \uparrow \text { the liver enzyme GSH } \\
\text { level }\end{array}$ & [260] \\
\hline
\end{tabular}


TABle 2: Continued.

\begin{tabular}{|c|c|c|c|c|c|c|}
\hline Plant name & $\begin{array}{l}\text { Extract and plant part } \\
\text { used }\end{array}$ & Test model & Dose & Route & Hepatoameliorative effects & Ref. \\
\hline \multirow{4}{*}{ E. alba } & $\begin{array}{l}\mathrm{MeOH} \text { leaves and } \\
\mathrm{CHCl}_{3} \text { root extract }\end{array}$ & $\begin{array}{c}\mathrm{CCl}_{4} \text {-induced liver damage in } \\
\text { rats }\end{array}$ & $250 \mathrm{mg} / \mathrm{kg}$ & Oral & Reduced lysosomal enzyme in blood & {$[66]$} \\
\hline & AQ leaf extract & $\begin{array}{l}\mathrm{CCl}_{4} \text {-induced hepatic injury in } \\
\text { rats }\end{array}$ & $250 \mathrm{mg} / \mathrm{kg}$ & Oral & $\begin{array}{c}\downarrow \text { the elevated AST, ALT, and ALP and } \uparrow \\
\text { the liver enzyme SOD, CAT, GPx, and } \\
\text { GST }\end{array}$ & [65] \\
\hline & AQ leaf extract & $\begin{array}{l}\text { EtOH-induced oxidative stress } \\
\text { on liver in rats }\end{array}$ & $250 \mathrm{mg} / \mathrm{kg}$ & Oral & $\begin{array}{l}\downarrow \text { the elevated AST, ALT, and ALP, as } \\
\text { well as } \uparrow \text { the liver enzyme SOD and CAT }\end{array}$ & {$[67]$} \\
\hline & $\begin{array}{l}\text { EtOH extract of aerial } \\
\text { parts }\end{array}$ & $\begin{array}{l}\text { CCl4-induced hepatotoxicity in } \\
\text { rat and mice }\end{array}$ & $62.5-500 \mathrm{mg} / \mathrm{kg}$ & Oral & $\begin{array}{c}\uparrow \text { protection of liver drug metabolizing } \\
\text { enzyme, } \uparrow \text { bromosulphalen (BSP) } \\
\text { clearance, and } \downarrow \text { the elevated AST, ALT, } \\
\text { and TB }\end{array}$ & [64] \\
\hline \multirow{3}{*}{ E. scaber } & EtOH extract of leaves & $\begin{array}{l}\text { Alcohol-induced liver damage in } \\
\text { mice }\end{array}$ & $\begin{array}{l}3,15 \text {, and } \\
30 \mathrm{mg} / \mathrm{kg}\end{array}$ & Oral & $\begin{array}{l}\downarrow \text { the elevated ALT, AST, and ALP level } \\
\text { to near the normal value }\end{array}$ & [68] \\
\hline & $\mathrm{MeOH}$ extract of root & $\begin{array}{l}\mathrm{CCl}_{4} \text {-induced liver damage in } \\
\text { rats }\end{array}$ & $\begin{array}{l}75 \text { and } \\
150 \mathrm{mg} / \mathrm{kg}\end{array}$ & Oral & $\begin{array}{l}\uparrow \text { antioxidant mechanisms, especially its } \\
\text { free-radical-scavenging activity, as well } \\
\text { as } \downarrow \text { the elevated ALT, AST, and ALP }\end{array}$ & [70] \\
\hline & $\begin{array}{l}\text { Dry root powder in } \\
\text { water }\end{array}$ & $\begin{array}{l}\mathrm{CCl}_{4} \text {-induced chronic liver } \\
\text { dysfunction in rat }\end{array}$ & $250-1500 \mathrm{mg} / \mathrm{kg}$ & Oral & $\downarrow$ the elevated AST, ALT, and ALP & {$[71]$} \\
\hline E. indica & $\begin{array}{l}\text { AQ extract of aerial } \\
\text { parts }\end{array}$ & $\begin{array}{l}\mathrm{CCl}_{4} \text {-mediated oxidative hepatic } \\
\text { damage in rats }\end{array}$ & $\begin{array}{l}150 \text { and } \\
300 \mathrm{mg} / \mathrm{kg}\end{array}$ & Oral & $\begin{array}{c}\uparrow \text { liver enzymes SOD, CAT, GSH, GST, } \\
\text { GR, and QR, as well as } \downarrow \text { the elevated } \\
\text { MDA, ALT, and AST }\end{array}$ & {$[261]$} \\
\hline E. tirucalli & AQ bark extract & $\begin{array}{l}\mathrm{CCl}_{4} \text {-induced hepatic damage in } \\
\text { rats }\end{array}$ & $\begin{array}{c}125 \text { and } \\
250 \mathrm{mg} / \mathrm{kg}\end{array}$ & Oral & $\begin{array}{l}\downarrow \text { the elevated liver markers, enzymes, } \\
\text { bilirubin, cholesterol, triglycerides, and } \\
\text { LPO, as well as } \uparrow \text { liver enzyme GSH }\end{array}$ & {$[262]$} \\
\hline G. pentaphylla & $\mathrm{MeOH}$ extract of leaves & $\begin{array}{l}\text { APAP-induced hepatic damage } \\
\text { in mice }\end{array}$ & $\begin{array}{c}200 \text { and } \\
400 \mathrm{mg} / \mathrm{kg}\end{array}$ & Oral & $\begin{array}{l}\downarrow \text { the elevated ALT, AST, ALP, TP, and } \\
\text { liver weight }\end{array}$ & [263] \\
\hline H. corymbosa & $\begin{array}{l}\text { EtOH extract of the } \\
\text { whole plant }\end{array}$ & $\begin{array}{l}\mathrm{CCl}_{4} \text {-induced hepatotoxicity in } \\
\text { rats }\end{array}$ & $500-3000 \mathrm{mg} / \mathrm{kg}$ & Oral & $\downarrow$ the elevated SGOT and SGPT & {$[264]$} \\
\hline H. japonicum & $\begin{array}{c}\text { AQ extract of the } \\
\text { whole plant }\end{array}$ & $\begin{array}{c}\mathrm{CCl}_{4} \text {-induced acute } \\
\text { hepatotoxicity in mice }\end{array}$ & $\begin{array}{c}0.5-4.5 \mathrm{gm} \mathrm{raw} \\
\text { material } / \mathrm{kg}\end{array}$ & Oral & $\downarrow$ the elevated AST, ALT, and TB & [265] \\
\hline H. auriculata & $\begin{array}{l}\text { Alkaloidal fraction of } \\
\text { MeOH leaves extract }\end{array}$ & $\mathrm{CCl}_{4}$-induced toxicity in rat & $80 \mathrm{mg} / \mathrm{kg}$ & Oral & $\begin{array}{c}\downarrow \text { the elevated AST, ALT, TG, ALP, TB, } \\
\text { and LDH }\end{array}$ & [266] \\
\hline I. tinctora & AQ extract of leaves & $\begin{array}{c}\text { INZ-induced hepatotoxicity in } \\
\text { albino rats }\end{array}$ & 5 and $10 \mathrm{~mL} / \mathrm{kg}$ & Oral & $\begin{array}{c}\downarrow \text { the elevated AST, ALT, ALP, TB, and } \\
\text { TP }\end{array}$ & [267] \\
\hline K. pinnata & EtOH extract of leaves & $\begin{array}{l}\text { CCl4-induced hepatotoxicity in } \\
\text { rat }\end{array}$ & $100 \mathrm{mg} / \mathrm{mL}$ & Oral & $\begin{array}{c}\downarrow \text { the elevated SGOT, SGPT, ALP, and } \\
\text { TB, as well as protect liver drug } \\
\text { metabolizing enzyme }\end{array}$ & [268] \\
\hline \multirow{5}{*}{ L. inermis } & AQ extract of leaves & $\begin{array}{c}\text { CCl4-induced hepatotoxicity in } \\
\text { rat }\end{array}$ & $1 \mathrm{~mL} / \mathrm{kg}$ & Oral & $\begin{array}{c}\downarrow \text { the elevated SGPT, SGOT, ALP, and } \\
\text { TB }\end{array}$ & [269] \\
\hline & $\begin{array}{l}50 \% \text { EtOH extract of } \\
\text { bark }\end{array}$ & $\begin{array}{l}\text { CCl4-induced oxidative stress in } \\
\text { rats }\end{array}$ & $\begin{array}{l}250 \text { and } \\
500 \mathrm{mg} / \mathrm{kg}\end{array}$ & Oral & $\begin{array}{l}\uparrow \text { liver antioxidant enzymes and } \\
\text { metabolizing enzymes, as well as } \downarrow \text { the } \\
\text { elevated SGPT, SGOT, and LDH }\end{array}$ & {$[270]$} \\
\hline & $\begin{array}{l}\text { Hydroalcoholic extract } \\
\text { of barks }\end{array}$ & $\begin{array}{l}\text { CCl4-induced liver toxicity in } \\
\text { rats }\end{array}$ & $20 \mathrm{mg} / \mathrm{mL}$ & Oral & $\begin{array}{l}\text { Upregulation of liver-metabolizing } \\
\text { enzymes and restored the elevated level } \\
\text { of serum liver biomarkers }\end{array}$ & [271] \\
\hline & $\mathrm{MeOH}$ extract of leaves & $\begin{array}{l}\text { CCl4-induced hepatotoxicity in } \\
\text { rat }\end{array}$ & $\begin{array}{c}100 \text { and } \\
200 \mathrm{mg} / \mathrm{kg}\end{array}$ & Oral & $\begin{array}{c}\downarrow \text { the elevated AST, ALT, ALP, and } \\
\text { bilirubin }\end{array}$ & [272] \\
\hline & $\begin{array}{l}\text { Butanolic fraction of } \\
\text { leaves }\end{array}$ & $\begin{array}{l}\text { 2-Acetylaminofluorene- (2-AAF- } \\
\text { ) induced hepatic damage in rats }\end{array}$ & $\begin{array}{l}100,200, \text { and } \\
400 \mathrm{mg} / \mathrm{kg}\end{array}$ & Oral & $\begin{array}{c}\downarrow \text { the elevated SGOT, SGPT, ALP, and } \\
\text { LPO as well as restored the normal liver } \\
\text { architecture }\end{array}$ & [273] \\
\hline M. arvensis & $\begin{array}{l}\mathrm{CHCl}_{3}, \mathrm{EtOH} \text {, and } \mathrm{AQ} \\
\quad \text { extract of leaves }\end{array}$ & $\begin{array}{l}\mathrm{CCl}_{4} \text {-induced liver damage in } \\
\text { rats }\end{array}$ & $375 \mathrm{mg} / \mathrm{kg}$ & Oral & $\begin{array}{c}\downarrow \text { the elevated SGOT, SGPT, ALP, and } \\
\text { TB and also preserved the liver tissue as } \\
\text { normal }\end{array}$ & {$[274]$} \\
\hline
\end{tabular}


TABle 2: Continued.

\begin{tabular}{|c|c|c|c|c|c|c|}
\hline Plant name & $\begin{array}{c}\text { Extract and plant part } \\
\text { used }\end{array}$ & Test model & Dose & Route & Hepatoameliorative effects & Ref. \\
\hline \multirow{6}{*}{ M. charantea } & $\begin{array}{l}\text { Hydroalcoholic extract } \\
\text { of leaves }\end{array}$ & $\mathrm{CCl}_{4}$-induced hepatopathy in rats & $\begin{array}{c}100 \mathrm{and} \\
200 \mathrm{mg} / \mathrm{kg}\end{array}$ & Oral & $\begin{array}{l}\downarrow \text { the elevated SGOT, SGPT, ALP, and } \\
\text { TB }\end{array}$ & [54] \\
\hline & AQ extract of fruit & $\begin{array}{l}\text { Liver injury in restraint-stressed } \\
\text { mice }\end{array}$ & $\begin{array}{l}250,500, \text { and } \\
750 \mathrm{mg} / \mathrm{kg}\end{array}$ & Oral & $\begin{array}{c}\downarrow \text { the elevated liver AST, ALT, and NO, } \\
\text { well as } \uparrow \text { activities of mitrochondrial } \\
\text { respiratory chain complex I and II }\end{array}$ & {$[56]$} \\
\hline & $\begin{array}{l}\text { Hydroalcoholic extract } \\
\text { of leaves }\end{array}$ & $\mathrm{CCl}_{4}$-induced hepatopathy in rats & $\begin{array}{l}100 \mathrm{and} \\
200 \mathrm{mg} / \mathrm{kg}\end{array}$ & Oral & $\begin{array}{l}\downarrow \text { the elevated SGOT, SGPT, ALP, and } \\
\text { TB }\end{array}$ & [55] \\
\hline & AQ extract of fruit & $\begin{array}{l}\text { Cyclophosphamide- (CP-) } \\
\text { induced hepatotoxicity in rats }\end{array}$ & $300 \mathrm{mg} / \mathrm{kg}$ & Oral & $\begin{array}{l}\downarrow \text { the elevated AST, ALT, ALP, TP, LDH, } \\
\text { and TB to normal values }\end{array}$ & {$[51]$} \\
\hline & AQ extract of leaves & $\begin{array}{c}\mathrm{CCl}_{4} \text {-induced hepatotoxicity in } \\
\text { rats }\end{array}$ & $\begin{array}{l}200 \text { and } \\
400 \mathrm{mg} / \mathrm{kg}\end{array}$ & Oral & $\begin{array}{c}\text { Restored the elevated level of AST, ALT, } \\
\text { ALP, and TB, as well as } \uparrow \text { liver enzyme } \\
\text { SOD and CAT }\end{array}$ & {$[53]$} \\
\hline & $\begin{array}{l}\text { Alcoholic extract of } \\
\text { fruit }\end{array}$ & $\begin{array}{l}\text { Ammonium chloride-induced } \\
\text { hyperammonemic rats }\end{array}$ & $300 \mathrm{mg} / \mathrm{kg}$ & Oral & $\begin{array}{l}\text { Restored the hepatic elevated level of } \\
\text { AST, ALT, and ALP, as well as } \uparrow \text { liver } \\
\text { antioxidant enzyme SOD, GPx, and CAT }\end{array}$ & {$[57]$} \\
\hline M. oleifera & $\mathrm{MeOH}$ extract of leaves & $\begin{array}{l}\text { Streptozotocin- (STZ-) induced } \\
\text { hepatotoxicity in diabetic rats }\end{array}$ & $250 \mathrm{mg} / \mathrm{kg}$ & Oral & $\begin{array}{l}\downarrow \text { the elevated AST, ALT, ALP, TP, and } \\
\text { TB to normal values, well as restored the } \\
\text { cytokine level including IL- } 6 \text {, monocyte } \\
\text { chemoattractant protein-1 (MCP-1), } \\
\text { and TNF- } \alpha\end{array}$ & {$[275]$} \\
\hline N. nucifera & $\begin{array}{l}50 \% \text { EtOH extract of } \\
\text { flower }\end{array}$ & $\begin{array}{c}\mathrm{CCl}_{4^{-}} \text {and APAP-induced } \\
\text { hepatopathy in rats }\end{array}$ & $\begin{array}{c}200 \mathrm{and} \\
400 \mathrm{mg} / \mathrm{kg}\end{array}$ & Oral & $\downarrow$ the elevated AST, ALT, ALP, and TB & [276] \\
\hline N. cristatum & $\begin{array}{l}50 \% \text { EtOH extract of } \\
\text { the whole plant }\end{array}$ & $\begin{array}{l}\text { CCl4-induced acute hepatic } \\
\text { damage in rats }\end{array}$ & $500 \mathrm{mg} / \mathrm{kg}$ & Oral & $\begin{array}{c}\downarrow \text { the elevated SGOT, SGPT, ALP, and } \\
\text { TB and preserved hepatic tissues to } \\
\text { normal }\end{array}$ & {$[277]$} \\
\hline O. basilicum & EtOH extract of laves & $\begin{array}{c}\mathrm{H}_{2} \mathrm{O}_{2^{-}} \text {and } \mathrm{CCl}_{4} \text {-induced } \\
\text { hepatotoxicity in goat liver }\end{array}$ & $100 \mathrm{mg} / \mathrm{kg}$ & Oral & $\begin{array}{c}\downarrow \text { the elevated AST, ALP, ALT, and } \\
\text { protein }\end{array}$ & [278] \\
\hline P. foetida & EtOH extract of leaves & $\begin{array}{l}\mathrm{CCl}_{4} \text {-induced hepatic lesions and } \\
\text { oxidative stress in rats }\end{array}$ & $200 \mathrm{mg} / \mathrm{kg}$ & Oral & $\begin{array}{c}\downarrow \text { the elevated LPO, GPT, GOT, ALP, } \\
\text { and TB }\end{array}$ & [279] \\
\hline P. acidus & $\begin{array}{c}\text { EtOH and AQ extracts } \\
\text { of leaves }\end{array}$ & $\begin{array}{l}\text { APAP- and TAA-induced hepatic } \\
\text { injuries in rats }\end{array}$ & $\begin{array}{l}200 \text { and } 400 \mathrm{mg} / \\
\mathrm{kg}\end{array}$ & Oral & $\begin{array}{c}\downarrow \text { the elevated oxidative stress and serum } \\
\text { AST, ALT, ALP, and TB }\end{array}$ & [280] \\
\hline P. emblica & AQ extracts of fruits & $\begin{array}{l}\text { APAP-induced hepatic damage } \\
\text { in rats }\end{array}$ & $\begin{array}{c}100 \mathrm{and} \\
200 \mathrm{mg} / \mathrm{kg}\end{array}$ & Oral & $\begin{array}{l}\text { Antioxidant properties were associated } \\
\text { with its liver protective activity }\end{array}$ & [281] \\
\hline P. oleracea & $\begin{array}{l}\text { AQ extract of aerial } \\
\text { parts }\end{array}$ & $\begin{array}{l}\text { CCl4-induced hepatopathy in } \\
\text { rats }\end{array}$ & $50 \mathrm{mg} / \mathrm{kg}$ & Oral & $\begin{array}{c}\downarrow \text { the elevated AST, ALT, ALP, TB, TP, } \\
\text { and TC. It also protects drug- } \\
\text { metabolizing enzymes }\end{array}$ & [282] \\
\hline P. indica & Alcoholic leaf extract & $\begin{array}{l}\mathrm{CCl}_{4} \text {-induced liver damage in } \\
\text { rats }\end{array}$ & $200 \mathrm{mg} / \mathrm{kg}$ & Oral & $\downarrow$ the elevated GOT, GPT, and ALP & [283] \\
\hline P. nigrum & $\begin{array}{c}\mathrm{AQ}, \mathrm{EtOH} \text {, and } \mathrm{CHCl}_{3} \\
\text { extract of root }\end{array}$ & $\mathrm{CCl}_{4}$-induced rat liver injury & $120 \mathrm{mg} / \mathrm{kg}$ & Oral & $\begin{array}{c}\downarrow \text { the elevated ALT, AST, and MDA, as } \\
\text { well as } \uparrow \text { liver enzyme GSH }\end{array}$ & {$[284]$} \\
\hline R. vesicarius & $\begin{array}{l}\mathrm{MeOH} \text { extract of the } \\
\text { whole plant }\end{array}$ & $\begin{array}{l}\mathrm{CCl}_{4} \text {-induced hepatotoxicity in } \\
\text { the rat model }\end{array}$ & $\begin{array}{l}100 \mathrm{and} \\
200 \mathrm{mg} / \mathrm{kg}\end{array}$ & Oral & $\begin{array}{l}\uparrow \text { liver enzyme SOD and CAT and } \downarrow \text { the } \\
\text { elevated SGPT, SGOT, ALP, MDA, and } \\
\text { TB }\end{array}$ & {$[285]$} \\
\hline S. nigrum & EtOH extract of leaves & $\begin{array}{l}\text { In vitro free-radical-mediated } \\
\text { DNA damage }\end{array}$ & NA & $\begin{array}{l}\text { Cell } \\
\text { culture }\end{array}$ & $\begin{array}{l}\text { Prevented the free-radical-mediated } \\
\text { oxidative degradation of DNA in the } \\
\text { liver tissue debris to protect the liver }\end{array}$ & [286] \\
\hline S. torvum & EtOH extract of fruits & $\begin{array}{l}\text { Doxorubicin- (DOX-) induced } \\
\text { hepatotoxicity in rats }\end{array}$ & $\begin{array}{c}100 \mathrm{and} \\
300 \mathrm{mg} / \mathrm{kg}\end{array}$ & Oral & $\begin{array}{c}\downarrow \text { the elevated ALT and AST and } \uparrow \text { liver } \\
\text { enzyme SOD and CAT }\end{array}$ & [287] \\
\hline S. oleracea & $\begin{array}{l}\text { PE, EtOH, and AQ } \\
\text { extract of seed }\end{array}$ & $\begin{array}{l}\mathrm{CCl}_{4} \text {-induced hepatotoxicity in } \\
\text { rats }\end{array}$ & $100 \mu \mathrm{g} / \mathrm{mL}$ & Oral & $\begin{array}{c}\text { Restoration of biochemical and } \\
\text { histological changes }\end{array}$ & [288] \\
\hline S. jambos & EtOH extract of leaves & $\mathrm{CCl}_{4}$-induced liver damage in rat & $300 \mathrm{mg} / \mathrm{kg}$ & Oral & $\begin{array}{l}\downarrow \text { the elevated SGPT, SGOT, ALP, TB, } \\
\text { TP, and liver weight }\end{array}$ & [289] \\
\hline T. purpurea & EtOH extract of leaves & $\mathrm{CCl}_{4}$-induced liver damage in rat & $100 \mathrm{mg} / \mathrm{kg}$ & Oral & $\downarrow$ the elevated ALP, AST, ALT, and TB & [162] \\
\hline T. arjuna & AQ extract of bark & INZ-induced liver toxicity in rat & $200 \mathrm{mg} / \mathrm{kg}$ & Oral & $\begin{array}{l}\downarrow \text { the elevated SGPT, SGOT, ALP, ACP, } \\
\text { TB, and protein, as well as } \uparrow \text { liver enzyme } \\
\text { GSH and SOD }\end{array}$ & [88] \\
\hline T. bellirica & $\begin{array}{l}\mathrm{AQ} \text { fraction of } \mathrm{MeOH} \\
\text { extract of fruit }\end{array}$ & $\begin{array}{l}\text { CCl4-induced liver injury in rats } \\
\text { and mice }\end{array}$ & $\begin{array}{l}50,100,200, \text { and } \\
400 \mathrm{mg} / \mathrm{kg}\end{array}$ & Oral & $\begin{array}{c}\uparrow \text { liver drug metabolizing enzyme and } \downarrow \\
\text { the elevated tranaminases, bilirubin, and } \\
\text { LPO }\end{array}$ & [93] \\
\hline T. chebula & EtOH extract of fruit & $\begin{array}{l}\text { Liver toxicity induced by RIF, } \\
\text { INZ, and PZA (in combination) }\end{array}$ & $\begin{array}{l}50,100, \text { and } \\
200 \mathrm{mg} / \mathrm{kg}\end{array}$ & Oral & $\begin{array}{c}\uparrow \text { antioxidative and membrane- } \\
\text { stabilizing activities, as well as } \downarrow \text { the } \\
\text { elevated SGPT, SGOT, ALP, and TB }\end{array}$ & [89] \\
\hline
\end{tabular}


TABle 2: Continued.

\begin{tabular}{|c|c|c|c|c|c|c|}
\hline Plant name & $\begin{array}{c}\text { Extract and plant part } \\
\text { used }\end{array}$ & Test model & Dose & Route & Hepatoameliorative effects & Ref. \\
\hline T. cordifolia & $\begin{array}{l}\text { Swaras and hima } \\
\text { extract of fresh stems }\end{array}$ & $\begin{array}{l}\text { APAP-induced hepatotoxicity in } \\
\text { mice }\end{array}$ & $200 \mathrm{mg} / \mathrm{kg}$ & Oral & $\downarrow$ the elevated SGOT and ALP & [290] \\
\hline $\begin{array}{l}T . \\
\text { portulacastrum }\end{array}$ & EtOH leaf extract & $\begin{array}{l}\text { APAP- and TAA-induced liver } \\
\text { toxicity in rats }\end{array}$ & $\begin{array}{c}100 \mathrm{and} \\
200 \mathrm{mg} / \mathrm{kg}\end{array}$ & Oral & $\begin{array}{c}\downarrow \text { the elevated SGOT, SGPT, ALP, and } \\
\text { TP }\end{array}$ & [291] \\
\hline T. dioica & $\begin{array}{c}\mathrm{AQ} \text { and EtOH extract } \\
\text { of aerial parts }\end{array}$ & $\begin{array}{l}\text { Ferrous sulphate- (FeSO4-) } \\
\text { induced liver injury in rats }\end{array}$ & $\begin{array}{c}100,200, \text { and } \\
400 \mathrm{mg} / \mathrm{kg}\end{array}$ & Oral & $\begin{array}{c}\downarrow \text { the elevated AST, ALT, TB, and ALP } \\
\text { and increased TP level }\end{array}$ & {$[292]$} \\
\hline \multirow[b]{2}{*}{ W. chinensis } & $\begin{array}{l}\text { Hot AQ extract of the } \\
\text { whole plant }\end{array}$ & $\begin{array}{l}\text { Acute hepatitis induced by } \mathrm{CCl}_{4} \text {, } \\
\text { APAP in mice, and } \mathrm{GNH}_{2} \text { in rats }\end{array}$ & $300 \mathrm{mg} / \mathrm{kg}$ & Oral & $\downarrow$ the elevated SGOT and SGPT & [293] \\
\hline & $\begin{array}{l}\text { EtOHc and AQ extract } \\
\text { of the whole plant }\end{array}$ & $\begin{array}{c}\mathrm{CCl}_{4} \text {-induced hepatotoxicity in } \\
\text { rat }\end{array}$ & $500 \mathrm{mg} / \mathrm{kg}$ & Oral & $\begin{array}{c}\downarrow \text { the elevated SGOT, SGPT, ALP, and } \\
\text { TB }\end{array}$ & [294] \\
\hline
\end{tabular}

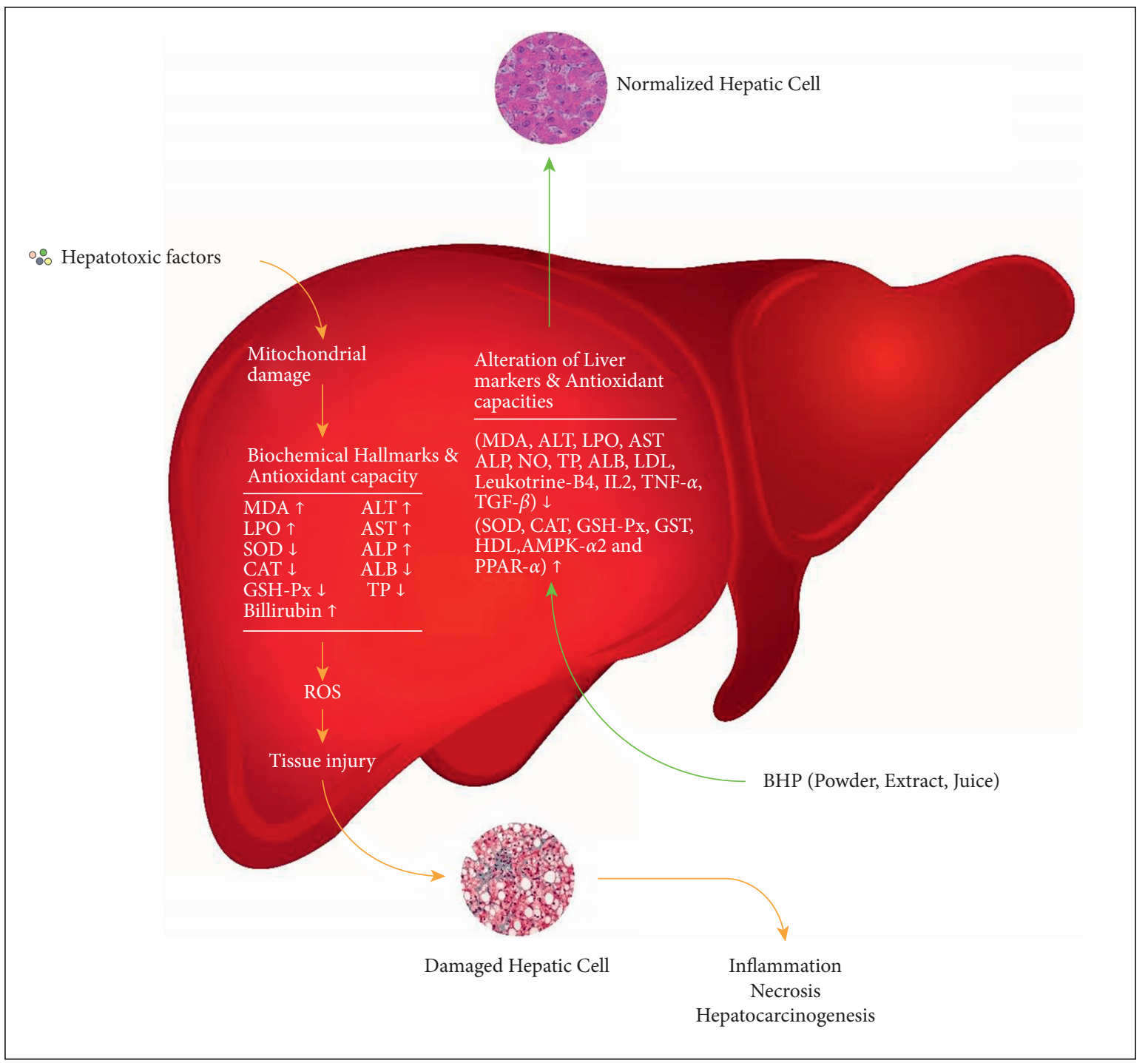

(BHP)- Bangladesh hepatoprotective plant

Figure 5: Effects of hepatotoxic chemicals and hepatoprotective plants on liver injury, inflammation, and oxidative stress.

3.1.3. Plants from Compositae/Asteraceae. Plants from Compositae (Asteraceae) have been used in traditional medicinal practice in Bangladesh to treat liver diseases for a long time. It is a large family of flowing plants which consists of over 32,000 species within over 1,900 genera and 13 subfamilies [58]. Decoction of different plant parts of local species Carthamus tinctorius, Eclipta alba, Elephantopus scaber, Sonchus wightianus, and Wedelia chinensis has been used in the treatment of liver diseases, including jaundice and enlargement of the liver (Table 1). The plant 
C. tinctorius, known as safflower, has been used as a hepatotonic in Unani medicine of India and Bangladesh, whereas in Jamaica and the Philippines, the flowers are used for jaundice [59].The $\mathrm{MeOH}$ extract of $C$. tinctorius flowers reported to protect $\mathrm{CCl}_{4}$-induced liver injury in rat via the antioxidant and anti-inflammatory mechanism, as well as reduced the level of biochemical markers (Table 2) [60]. The seed oil and leaf extract of $C$. tinctorius also possess liver protective activity and showed protective effect via reducing the liver toxicity biomarkers in alloxen-induced diabetic rat or $\mathrm{CCl}_{4}$-induced liver toxicity in rat $[61,62]$.

$E$. alba is an annual herb that is traditionally used in Bangladesh against jaundice and enlargement of the liver [26]. In India, the plant has been used as a tonic and in the treatment of enlargement of the liver [63]. It has also been reported to be used in Ayurvedic medicine to treat infective hepatitis in adults and children [64]. In Chinese medicine, the palnt has use in liver and kidney problems [65]. Sing showed that E. alba is safe up to $2 \mathrm{~g} / \mathrm{kg}$ in mice [64], and later, Lal demonstrated the $\mathrm{LD}_{50} 5 \mathrm{~g} / \mathrm{kg}$ [66]. The aqueous extract of $E$. alba leaf showed protection against liver damage induced by either $\mathrm{CCl}_{4}$ or ethanol in rat via reduced oxidative stress on the liver by elevating the antioxidant enzyme level (Table 2) $[65,67]$. Another study conducted by Lal showed that the $\mathrm{MeOH}$ extract of leaves and $\mathrm{CHCl}_{3}$ extracts of roots reduced the level of lysosomal enzyme and protected from hepatic damage in $\mathrm{CCl}_{4}$-treated rats [66]. The dosedependent hepatoprotective effect $\quad(62.5-500 \mathrm{mg} / \mathrm{kg})$ exhibited by alcoholic aerial part extract of $E$. alba was found to be due to some protection of hepatic drug-metabolizing enzymes, and it restored the impaired excretory capacity of the liver in $\mathrm{CCl}_{4}$-treated animals [64].

The crused roots of E. scaber are used traditionally to treat liver diseases in Bangladesh [26]. In Malaysia, the plant has been used as a liver tonic, whereas in Brazil, root juice has a common use in treating liver troubles and hepatitis [68]. In China, a herbal drink Yi-GanYin containing E. scaber is used to protect the liver against different diseases including liver cancer, cirrhosis, and hepatitis [69]. TengKhia- $U$ is another Taiwanease herbal medicine that also contains E. scaber with other plants and claimed to possess hepatoprotective and anti-inflammatory activity [70]. The alcoholic extract of the root and leaves of E. scaber reported to possess antioxidant activity and reduced the oxidative stress in rat treated with $\mathrm{CCl}_{4}$ or ethanol and protect from liver damage dose dependently (Table 2) [68, 70, 71].

3.1.4. Plants from Acanthaceae. Andrographis paniculata Burm. (Acanthaceae) is a common and widely used medicinal plant from South-East Asia, including Bangladesh, that has been used to treat liver diseases $[26,72,73]$. The leaves and aerial parts of this plant have also been used in Chinese medicine against liver problems [74]. In the Ayurveda system, about twenty-six different polyherbal preparations containing this plant have been recorded [75]. A. paniculata extract has also been reported to be effective in ameliorating the chronic hepatitis $B$ virus infection [76]. A number of animal studies were conducted with ethanolic or aqueous extract of leaves of A. paniculata supplementation against different hepatotoxin (TAA, APAP, $\mathrm{CCl}_{4}$, and hexachlorocyclohexane (BHC))-induced liver toxicity in the rat or mice model, and the results demonstrated that supplementation of A. paniculata normalized cellular oxidative stress and dose-dependently protected against liver toxicity as assessed in terms of either reduced serum marker enzymes, as well as restored the liver tissues antioxidant enzymes (Table 2) [77-80]. A. paniculata extract at a dose of $50-200 \mathrm{mg} / \mathrm{kg}$ could protect the liver by restoring antioxidant enzymes as well as reduction (appx. 33-48\%) of lipid peroxidation in the liver [81]. The plant extract contains different phenolic phytoconstituents and believed to act as antioxidants as a part of its mechanism of lipid peroxidation $[82,83]$. The water extract of the plant exhibited greater antioxidant activity than ethanolic extract because of high phenolic contents in water extract than ethanolic extract $[84,85]$.

3.1.5. Plants from Combretaceae. A number of species of the genus Terminalia belonging to the Combretaceae family have been used to treat liver problems in the traditional medicinal practice of Bangladesh. Terminalia arjuna, Terminalia chebula, and Terminalia belerica are three important medicinal plants that have been used in Ayurvedic medicine for over centuries, primarily as a tonic for the heart and liver $[86,87]$. The use of aqueous bark and ethanolic fruit extracts of T. arjuna and T. chebula showed liver-protective activity in antitubercular drug (single INZ or in combination of RIF, INZ, and pyrazinamide (PZA))-induced liver toxicity in rats at a dose of $50-200 \mathrm{mg} / \mathrm{kg}$ (Table 2). The hepatoprotective effect of these extracts was due to their prominent antioxidative and membrane-stabilizing activities [88, 89]. Pretreatment of rats with the extract of T. arjuna bark and T. chebula fruit also showed the hepatoprotective potential against paracetamol-/ $\mathrm{CCl}_{4}$-induced liver damage through a significant reduction of serum liver marker enzymes, which was comparable to silymarin [90-92]. The hepatoprotective activity of $T$. belerica fruit extract was observed by shortened hexobarbitone sleeping time and zoxazolamine paralysis time by inducing drug-metabolizing enzyme and dose-dependent elevation of serum transaminases and bilirubin in $\mathrm{CCl}_{4}$-induced liver injury rats [93].

3.1.6. Plants from Papilionaceae. Cajanus cajan (Papilionaceae) is another popular Bangladeshi plant which has been used in local traditional medicinal practice to treat liver diseases [26]. The juice of leaves is used to treat jaundice by the folklore practitioners of Bangladesh and India $[26,52]$. A number of investigations were conducted to evaluate C. cajan extract for its liver-protective activity (Table 2). Pretreatment of alcoholic extract of $C$. cajan leaves or aerial parts showed liver-protective activity via the reduction of elevated liver enzymes in $\mathrm{CCl}_{4}$ - or APAP-induced liver injury rats $[94,95]$, as well as antiperoxidative activity by induction of the antioxidant enzymes, namely, CAT, SOD, GPx, and GST, in hepatitis rats induced by $\mathrm{GNH}_{2}$ [96]. The 
methanolic aqueous fraction of C. cajan leaves protects from hepatocyte in alcohol-induced liver-damaged rat through normalized UDP-glucuronosyl transferase (UGT) activity and upregulates the expression of UGT-2B with nuclear translocation of nuclear factor erythroid-2-related factor-2 (Nrf2) [97].

3.1.7. Plants from Caesalpiniaceae. The plants Cassia fistula and Caesalpinia bonducella belonging to the family Caesalpiniaceae have been used in the treatment of liver diseases, and a number of reports have been published on their different parts that possess liver-protective activity (Table 2). In vivo data showed that the liver-protective effect by different extracts of C. fistula were observed at doses $200-800 \mathrm{mg} / \mathrm{kg}$ (b.w) via decreasing various elevated liver biomarkers in chemical-induced liver toxicity in animals (Table 2) [98-102]. Drug-induced hepatotoxicity was also prevented by the ethanolic extract of leaves of $C$. fistula by reduced oxidative stress and other liver biomarkers in diethyl nitrosamine or INZ with RIF-induced liver toxicity in rats $[103,104]$, whereas the alcoholic or AQ extract of leaves of C. bonducella showed hepatoprotective activity observed by decreasing the activity of serum liver biomarkers [105-107] as well as reduced oxidative stress via increasing the levels of antioxidant enzymes [108, 109].

3.1.8. Plants from Liliaceae. Aloe barbadensis (Aloe vera) and Asparagus racemosus are two popular ethnomedicinal plants belonging to the Liliaceae family that have been used to treat liver diseases. Different hepatotoxin-induced liver toxicities in rat models were used to evaluate their liverprotective activity (Table 2). Among these, the fresh AQ extract of $A$. barbadensis has been studied for its hepatoprotective activity in a various animal models, and the results confirmed its protective activity that could play a therapeutic role against in either $\mathrm{CCl}_{4}$, APAP, alcohol, or drugs (lindane, INZ, or RIF)-induced liver damage by improving liver enzyme activities and improved antioxidant enzymes in intoxicated rat liver tissue [110-114].

A Korean pharmaceutical preparation of $A$. barbadensis called ACTIValoe ${ }^{\circledR} \mathrm{N}-931$ (mixture of $A$. barbadensis and Silybum marianum extracts) has been studied interperitoneally in the $\mathrm{CCl}_{4}$-induced hepatotoxicity and liver fibrosis rat model, and the results demonstrated that both acute hepatotoxicity and liver fibrosis were prevented via restoring the serum aminotransferase, lipid peroxidation, and increasing the hepatic glutathione content. The ACTIValoe ${ }^{\circledR} \mathrm{N}-931$ also attenuated the increase in TNF- $\alpha$ and induced nitric oxide synthase (iNOS), cyclooxygenase- 2 (COX-2), and mRNA expressions in acute hepatotoxicity induced by $\mathrm{CCl}_{4}$ in rats [115]. Besides the in vivo assays, a clinical study was also conducted using the fresh juice of A. barbadensis among male and female patients of age 15-65 years diagnosed clinically and biochemically with acute viral hepatitis. A number of liver biochemical markers were measured at the end of 2, 4, and 6 weeks, and it was found that the juice extract of the plant has liver-protective activity compared to the control group, which confirmed the traditional uses of $A$. barbadensis for the treatment of liver diseases [116].

3.1.9. Plants from Zingiberaceae. Curcuma longa (turmeric; Zingiberaceae) has been used as a herbal medicine owing to its multipharmacological activities [117, 118]. It has been used locally in traditional medicine for the treatment of liver diseases (Table 2). Liver cirrhosis induced by TAA in rats was prevented by the ethanolic extract of turmeric through the inhibition of oxidative stress markers and upregulation of liver antioxidant enzymes and the anti-inflammatory mechanism which restored the elevated cytokines TGF- $\beta 1$ and TNF- $\alpha$, as well as enhanced apoptosis of damaged hepatocytes as a protective mechanism and downregulated inflammatory effects and fibrogenesis of the liver [119]. Liver-protective activity through upregulation of hepatic antioxidant enzymes and restoring of various liver biomarkers by the crude extract of $C$. longa were also supported by other studies of this plant with similar activity in different hepatotoxin $\left(\mathrm{CCl}_{4}, \mathrm{GNH}_{2}\right.$, or tubercular drug)-induced liver damage in the animal model [120-122]. Other reports also showed that alcoholic extract of turmeric alleviate of hepatotoxic effects caused by $\mathrm{HgCl}_{2}$ in rats through a protective effect on drug metabolizing CYP-2E1 enzymes, viz., aniline hydroxylase (AH) and amidopyrine-N-demethylase (AND) [123]. The extract of turmeric also reported to improve liver activity via enhancing its antioxidant activity in alloxaninduced diabetic rat liver toxicity [124].

3.1.10. Plants from Other Families. A number of other traditional plants belonging to various families also have been used in the management of liver diseases. Amaranthus spinosus (Acanthaceae) is a leafy vegetable that has been used to treat jaundice. A number of studies found on its extracts of whole plant showed dose-dependent $(100-400 \mathrm{mg} / \mathrm{kg})$ liver-protective activity against various hepatotoxin $\left(\mathrm{CCl}_{4}\right.$, $\mathrm{GNH}_{2}$, and APAP)-induced liver toxicity in rats via induction of liver antioxidant enzymes and inhibiting oxidant enzyme MDA, as well as restored the elevated level of serum liver biomarkers and cellular architecture [125-127]. The latex and extract of Argenome mexicana (Papaveraceae) have been reported to be used in the herbal medicine to treat jaundice in Bangladesh. Literature study found that the supplementation of leaf extract or dietary leaves of A. mexicana has the ability to reduce the activities of liver marker enzymes and protect against liver injury induced by $\mathrm{CCl}_{4}$ in rat models [128-130]. Similarly, Bixa orellana (Bixaceae) also reported to possess inhibition of elevated liver biomarker enzymes activities of $\mathrm{CCl}_{4}{ }^{-}$or $\mathrm{EtOH}$-included hepatotoxic rats to protect against liver injury (Table 2) $[95,131-133]$.

The hepatoprotective activity of various parts of Boerhavia diffusa (Nyctaginaceae) has been well studied in different hepatotoxin (TAA, $\mathrm{CCl}_{4}, \mathrm{EtOH}$, and IB)-induced rat liver toxicity (Table 2 ). The $\mathrm{MeOH}$ extract of $B$. diffusa root restored the elevated liver markers and reduced oxidative stress, as well as normalized liver histological changes, to protect against hepatotoxicity in ibuprofen- (IB-) induced 
liver toxicity in rats [134]. The alcoholic or hydroalcoholic extract of $B$. diffusa whole plant showed protective activity in $\mathrm{CCl}_{4}$-induced liver injury rat via the protection of drugmetabolizing enzymes and restored the elevated liver biomarkers, as well as increased bile flow of the liver [135, 136].

Carica papaya (Carieaceae) is another common species that has been used extensively in the liver problem, especially its fruit, either as cooking of unripe fruit or raw eating of ripe fruit [26]. The AQ extract of C. papaya leaves and unripe fruit at an oral dose of $100-300 \mathrm{mg} / \mathrm{kg}$ showed upregulation of antioxidant enzyme activities in liver tissues and decreased serum liver markers, as well as decreased reduced lipid peroxidation as a protective mechanism in $\mathrm{CCl}_{4^{-}}$or APAP-induced hepatotoxicity in rats [137]. The AQ extract of ripe/unripe seeds or dried fruit or $\mathrm{MeOH}$ extract of stalk of C. papaya also has liver-protective potential that can hamper the activity of liver biomarker enzymes in $\mathrm{CCl}_{4}$ induced hepatotoxic rats (Table 2) [138-141]. Daucas carota (carrot; Umbelliferae) is another common functional food that has medicinal uses against liver disease. The AQ extract of tuber of $D$. carota showed protective activity against LD-, APAP-, INZ-, or EtOH-induced liver toxicity in rats through altering lipid profile, restored depressed antioxidant systems, and decreased levels of serum enzymes (Table 2) [142, 143]. Similar activity was also found for the oil extract and its phenolic rich fraction in $\mathrm{CCl}_{4}$-induced hepatic injury rats where the oil extract showed hepatoprotective activity via reduction of cellular oxidative stress and restored the elevated levels liver markers [144].

\subsection{Antioxidative Plants for Hepatoprotection.} Hepatotoxicity or hepatic injury or liver damage occurs mainly through oxidative stress, inflammation, or lipid peroxidation which ultimately inhibits liver regeneration, mitochondrial damage, and finally, cell death [145]. As a consequence, a number of biochemical marker alterations and upregulatin of cellular antioxidative defense mechanisms occurred as a reflection of hamper of liver function (Figure 5) [145]. Treatment with antioxidant can prevent and cure liver diseases by balancing oxidative stress. It is reported that antioxidants can enhance dissociation of $\mathrm{Nrf} 2$ from the complex by either modifying kelch-like ECH-associated protein-1 (Keap1) or Nrf2 phosphorylation which causes activation of Nrf2 (Figure 6). The activated Nrf2 translocates into the nucleus, binds to antioxidant response element (ARE), and upregulates the gene expression of antioxidant enzymes and phase II detoxifying enzymes, which protects and cures cellular damage [146]. A number of reports also showed that some antioxidants or antioxidant-rich plant extracts protect against hepatotoxin-induced liver damages by upregulation of activation of Nrf2 [147-149].

A number of other indigenous ethnomedicinal plants belonging to different families have also reported its hepatoprotective activity through their antioxidant mechanism (Table 2). However, a number of plants have been used in traditional medicine to treat liver diseases, although no report was found on their selective hepatoprotective activity, including Aloe indica, Allamanda cathartica, Anagallis arvensis, Borassus flabellifer, Caesalpinia pulcherrima, Corchorus capsularis, Corchorus olitorius, Croton caudatus, Croton oblongifolius, Flacourtia jangomas, Ipomoea aquatica Forsk., Justicia gendarass Burm., Lagenaria siceraria, Mussaenda glabrata, Meyna spinosa, Phyllanthus freternus, Piper longum, Pavetta indica, Saccharum officinarum, Sonchus wightianus, Semecarpus anacardium, and Tamarix troupiihole (Table 1). Therefore, these Bangladeshi medicinal plants could be a promising source to explore further to evaluate their liver protective activity and further identify the active principle.

3.3. Hepatoprotective Phytoconstituents. Natural product small molecules (NPSMs) or active fractions containing NPSMs that possess different pharmacological actions, especially antioxidant and anti-inflammatory activity, have recently attracted potential attention to treat liver diseases [150]. A variety of plants and fruits have been used to protect liver function that possess different phytoconstituents including phenolics, flavonoids, coumarins, alkaloids, essential oils, glycosides, xanthenes, carotenoids, organic acids, lignins, and monoterpenes [151]. A number of hepatoprotective phytoconstituents belonging to different chemical classes have been isolated and reported so far from these Bangladeshi plants (Table 3). The various active constituents isolated from these plants were assembled based on the class of compounds as follows.

3.3.1. Flavoinoid and Phenolic Compounds. Flavonoid and phenolic compounds occur ubiquitously in plants and are well-known antioxidant and anti-inflammatory compounds [152]. Several investigations on natural antioxidant, especially flavonoids and phenolics from plants, showed a potential effect in different diseases caused by oxidative stress including liver diseases [153]. A number of previous studies demonstrated that these flavonoids can prevent and cure hepatotoxin-induced liver injury in rodents [154-156].

The hepatoprotective plants A. spinosus, C. tinctorius, C. fistula, S. jambos, and T. purpurea possess flavonoids as a major constituent, and a number of reports showed the hepatoprotective activity of these plants due to their active flavonoids (Table 3). Rutin (1), kaempferol 3-O-rutinoside (2) or -glucoside (3) (336-672 $\mu \mathrm{M} / \mathrm{kg})$, and catechin (4) $(69 \mu \mathrm{M} / \mathrm{kg})$ flavonoids were isolated from A. spinosus, C. tinctorius, and C. fistula, respectively, that exhibited hepatoprotective activity in $\mathrm{CCl}_{4}$ - or STZ-induced rat liver toxicity (Table 3 and Figure 7 ). The study revealed that these flavonoids significantly upregulate enzymatic antioxidant systems and regeneration of hepatocytes and, as a result, reduced the elevated serum liver biomarker suggesting their liver-protective effect (Figure 5) [157-159]. Although these studies did not highlight any molecular mechanism of their liver-protective activity, it is well reported that the hepatoprotective activity of these flavonoids might be due to their free-radical-scavenging activity with their anti-inflammatory and antifibrotic responses as well as induction of the Nrf2 signaling pathway (Figure 6) $[155,160,161]$. 


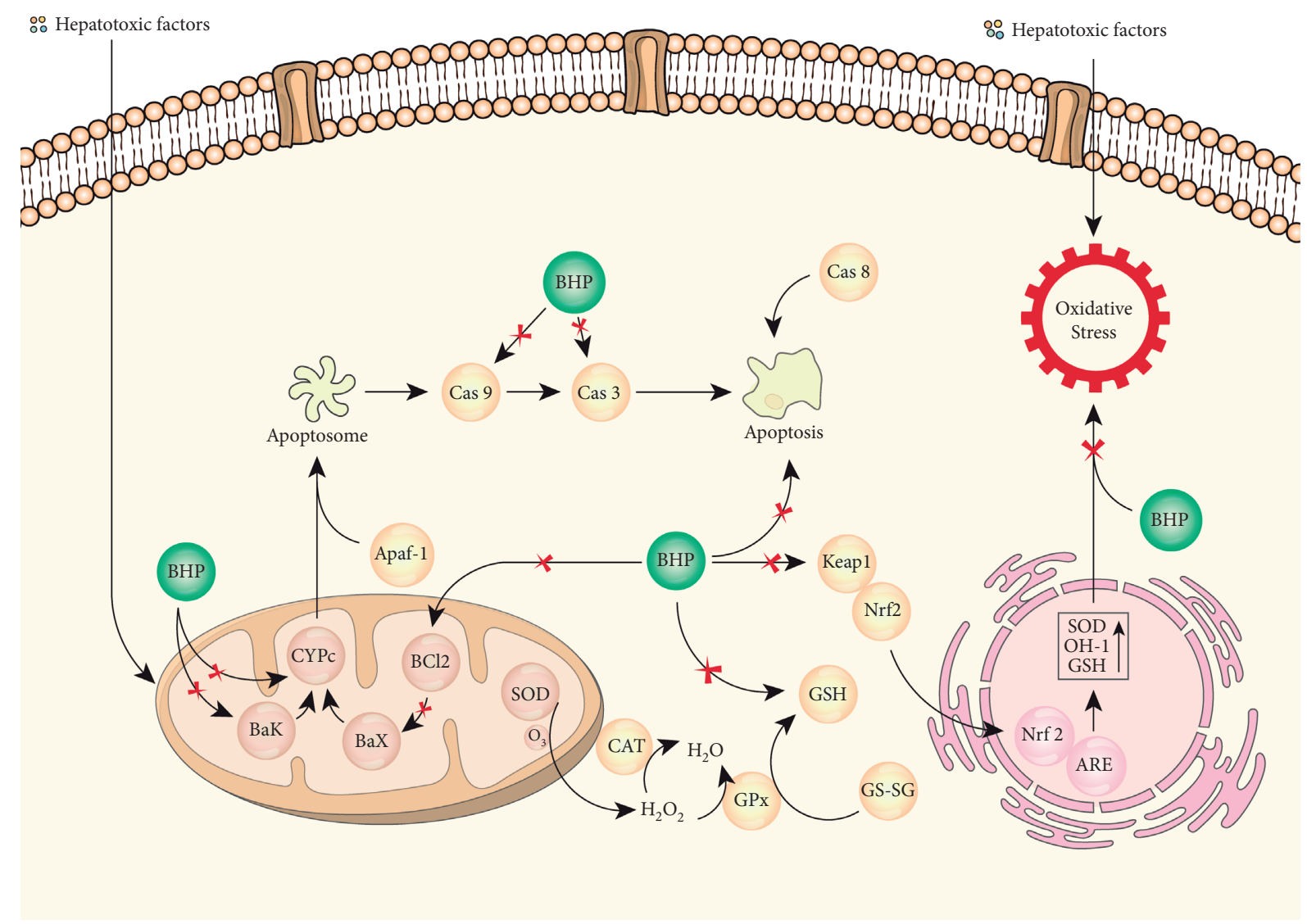

(BHP)- Bangladeshi Hepatoprotective Plant

Figure 6: Proposed molecular mechanism of hepatoprotective activity.

TABLE 3: List of lead hepatoprotective compounds isolated form Bangladeshi traditional plants.

\begin{tabular}{|c|c|c|c|c|c|c|}
\hline Plant name & Isolated compound & Test model & Dose & Route & $\begin{array}{c}\text { Mechanism of hepatoprotective } \\
\text { action }\end{array}$ & Ref. \\
\hline \multirow{5}{*}{ A. vera } & Polysaccharides & $\begin{array}{l}\text { Alcohol-induced liver diseases in } \\
\text { mice }\end{array}$ & $10 \mathrm{mg} / \mathrm{kg}$ & IP & $\begin{array}{l}\text { Reduced liver biomarkers via } \\
\text { increasing lipolysis through } \\
\text { upregulating hepatic expression } \\
\text { of lipolytic genes AMPK- } \alpha 2 \text { and } \\
\text { PPAR } \alpha \text {, as well as reduced } \\
\text { hepatic inflammation via } \\
\text { downregulation of TLR- } 4 \text { and } \\
\text { MyD88 with upregulation of I } \kappa \text { B- } \\
\alpha\end{array}$ & {$[236]$} \\
\hline & Aloe emodin & $\begin{array}{l}\text { Myofibroblastic differentiation } \\
\text { study in rat hepatic stellate cells }\end{array}$ & $\begin{array}{c}0.004-0.04 \mu \mathrm{M} / \\
\mathrm{mL}\end{array}$ & $\begin{array}{c}\text { Cell } \\
\text { culture }\end{array}$ & $\begin{array}{l}\text { Inhibition of stellate cell } \\
\text { proliferation by reduced DNA } \\
\text { synthesis and inhibition of type I } \\
\text { collagen production and smooth } \\
\text { muscle alpha-actin expression }\end{array}$ & {$[221]$} \\
\hline & & $\mathrm{CCl}_{4}$-induced hepatic injury in rats & $185 \mu \mathrm{M} / \mathrm{kg}$ & IP & $\begin{array}{l}\text { Reduced hepatocyte death and } \\
\text { inflammation through inhibition } \\
\text { of TNF- } \alpha \text { and LPO }\end{array}$ & {$[220]$} \\
\hline & \multirow[t]{2}{*}{ Aloin } & $\begin{array}{l}\text { Alcohol-induced liver injury in } \\
\text { mice }\end{array}$ & $\begin{array}{l}24 \text { and } 72 \mu \mathrm{M} / \\
\mathrm{kg}\end{array}$ & Oral & $\begin{array}{l}\text { Attenuated lipid accumulation } \\
\text { via inhibition of SREBP-1c } \\
\text { regulate gene, as well as reduced } \\
\text { hepatic inflammation through } \\
\text { downregulation of TLR-4 and } \\
\text { TNF- } \alpha\end{array}$ & {$[223]$} \\
\hline & & TAA-induced hepatic retinopathy & $\begin{array}{c}120 \text { and } \\
240 \mu \mathrm{M} / \mathrm{kg}\end{array}$ & Oral & $\begin{array}{l}\text { Suppressed retinal injury } \\
\text { associated with liver toxicity } \\
\text { through the normalization of } \\
\text { Kir4.1 and aquaporin-4 channels }\end{array}$ & {$[224]$} \\
\hline
\end{tabular}


TABLE 3: Continued.

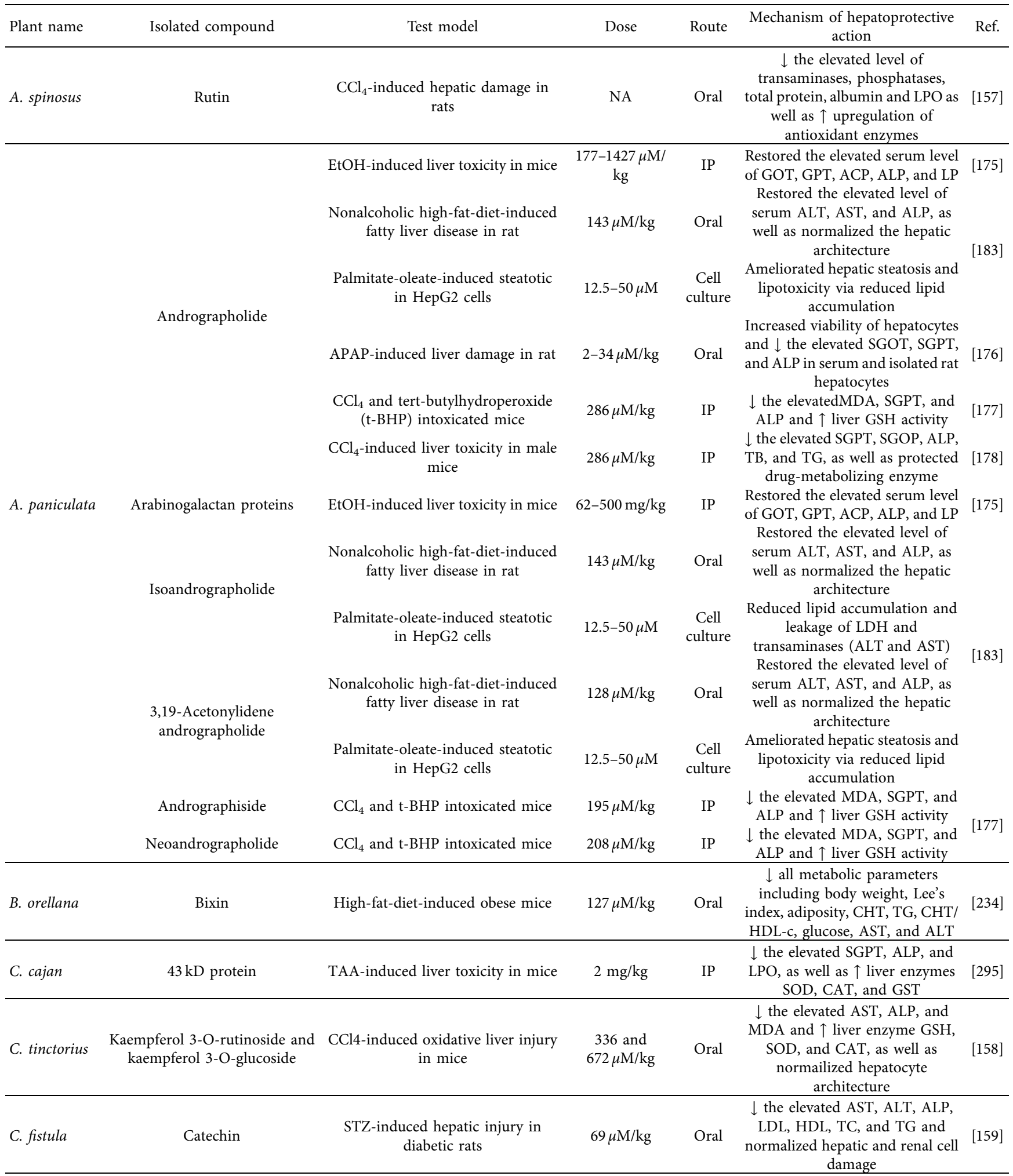


TABle 3: Continued.

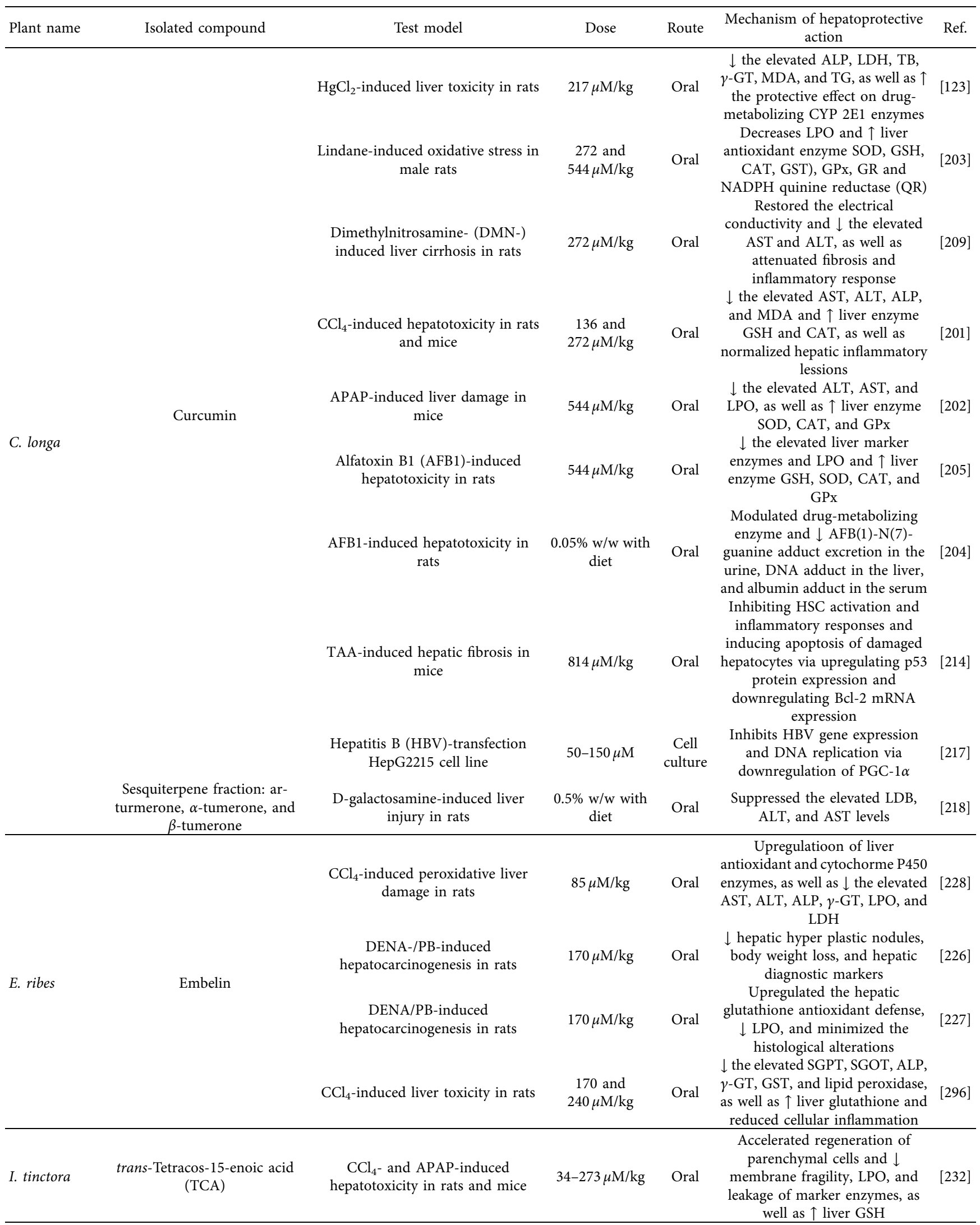


TABle 3: Continued.

\begin{tabular}{|c|c|c|c|c|c|c|}
\hline Plant name & Isolated compound & Test model & Dose & Route & $\begin{array}{l}\text { Mechanism of hepatoprotective } \\
\text { action }\end{array}$ & Ref. \\
\hline L. inermis & Gallic acid & $\mathrm{CCl}_{4}$-induced hepatotoxicity in rats & $294 \mu \mathrm{M} / \mathrm{kg}$ & IP & $\begin{array}{l}\downarrow \text { the elevated ALT, AST, ALP, } \\
\text { LDH, and ROS, as well as } \uparrow \text { liver } \\
\text { SOD, CAT, and GPx and } \\
\text { normalized hepatocellular } \\
\text { architecture }\end{array}$ & {$[170]$} \\
\hline \multirow[t]{2}{*}{ M. charantea } & $\begin{array}{l}\text { Cucurbitane-type triterpene } \\
\text { glycosides }\end{array}$ & $\begin{array}{l}\text { Antihepatic fibrosis activity against } \\
\text { murine hepatic stellate cells (t-HSC/ } \\
\text { Cl-6) and antihepatoma activity in } \\
\text { HepG } 2 \text { and Hep3B cells }\end{array}$ & Upto $100 \mu \mathrm{M}$ & $\begin{array}{c}\text { Cell } \\
\text { culture }\end{array}$ & $\begin{array}{l}\text { Inhibition the activation of t- } \\
\text { HSC/Cl- } 6 \text { cells and } \downarrow \text { cytotoxicity } \\
\text { of Hep3B and HepG } 2 \text { cells }\end{array}$ & [197] \\
\hline & $\begin{array}{l}\text { Norcucurbitane-type } \\
\text { triterpenoids }\end{array}$ & $\begin{array}{l}t \text {-BHP-induced injury on HepG2 } \\
\text { cells }\end{array}$ & $5-10 \mu \mathrm{M}$ & $\begin{array}{c}\text { Cell } \\
\text { culture }\end{array}$ & $\uparrow$ the viability of HepG2 cells & {$[198]$} \\
\hline O. basilicum & $\begin{array}{c}\text { Triterpene acid: betulinic, } \\
\text { oleanolic, ursolic, alphitolic, } 3 \text { - } \\
\text { epimaslinic, and euscaphic acids }\end{array}$ & $\begin{array}{l}\text { Iron ascorbate-stimulated lipid } \\
\text { peroxidation in liver homogenate }\end{array}$ & $0.1-5 \mathrm{mg} / \mathrm{mL}$ & $\begin{array}{c}\text { Cell } \\
\text { culture }\end{array}$ & $\begin{array}{l}\downarrow \text { liver oxidative stress by } \\
\text { inhibition of LPO }\end{array}$ & [187] \\
\hline P. olerace & $\begin{array}{c}\text { Portulene diterpene, lupeol, b- } \\
\text { sitosterol, and daucosterol }\end{array}$ & $\begin{array}{l}\mathrm{CCl}_{4} \text {-induced hepatic toxicity in } \\
\text { rats }\end{array}$ & $10-50 \mathrm{mg} / \mathrm{kg}$ & Oral & $\begin{array}{c}\downarrow \text { the elevated level of SGOT, } \\
\text { SGPT, and TB }\end{array}$ & {$[184]$} \\
\hline S. jambos & $\begin{array}{l}\text { Flavonoid fraction: myricetin, } \\
\text { ellagic acid rahmnoside, } \\
\text { quercetin } 3 \text {-O-xylosyl- }(1 \longrightarrow 2) \text {, } \\
\text { rhamnoside, and rosmarinic } \\
\text { acid }\end{array}$ & $\begin{array}{l}\text { Sodium arsenite-induced oxidative } \\
\text { stress in HepG2 hepatocytes }\end{array}$ & $200 \mathrm{mg} / \mathrm{kg}$ & $\begin{array}{c}\text { Cell } \\
\text { culture }\end{array}$ & $\begin{array}{c}\downarrow \text { the elevated liver markers ALT, } \\
\text { AST, TB, TC, TG, and MDA, as } \\
\text { well as } \uparrow \text { liver enzyme GSH and } \\
\text { SOD } \\
\downarrow \text { the ROS production via } \\
\text { inhibition of p38 and its target } \\
\text { MAPKAPK-2-activated signaling } \\
\text { cascade }\end{array}$ & [167] \\
\hline T. purpurea & $\begin{array}{c}\text { Flavonoid fraction: Coumarins, } \\
\text { flavonoids, flavanones, and } \\
\text { quercetin }\end{array}$ & $\mathrm{CCl}_{4}$-induced hepatotoxicity & $100 \mathrm{mg} / \mathrm{kg}$ & Oral & $\begin{array}{l}\downarrow \text { the elevated liver markers } \\
\text { SGOT, SGPT, ALP, and bilirubin }\end{array}$ & {$[162]$} \\
\hline T. chebula & Chebulic acid & $\begin{array}{l}\text { t-BHP-induced oxidative stress in } \\
\text { HepG2 cells }\end{array}$ & $\begin{array}{l}0.4,2 \text {, and } \\
10 \mu \mathrm{M}\end{array}$ & $\begin{array}{c}\text { Cell } \\
\text { culture }\end{array}$ & $\begin{array}{c}\downarrow \text { the ROS and cell cytotoxicity } \\
\text { and the ratio of GSSH with GSH } \\
\downarrow \text { the oxidative stress through } \\
\text { controlling the activation of Nrf2 } \\
\text { and its cytoprotective enzymes } \\
\text { HO- } 1 \text { and } \gamma \text {-GCL }\end{array}$ & {$[172]$} \\
\hline
\end{tabular}

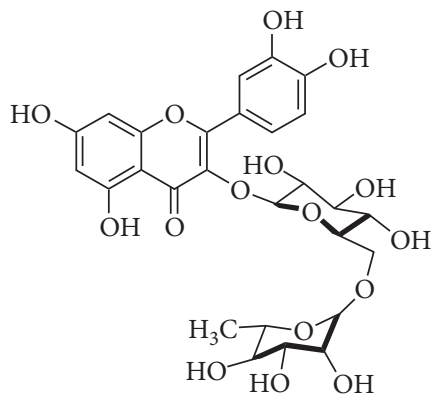

Rutin (1)<smiles>O=C1c2c(O)cc(O)cc2O[C@@H](c2ccc(O)c(O)c2)[C@@H]1O</smiles>

Catechin (4)<smiles>O=c1c(OC2OC3C(O)C(CO)C(CO)C(O)C3O2)c(-c2ccc(O)cc2)oc2cc(O)cc(O)c12</smiles>

Kaempferol 3-O-glucoside (2)<smiles>O=c1c(O)c(-c2ccc(O)c(O)c2)oc2cc(O)cc(O)c12</smiles>

Quercetin (5)<smiles>O=c1cc(-c2ccc(O)c(O)c2)oc2cc(O)cc(O)c12</smiles>

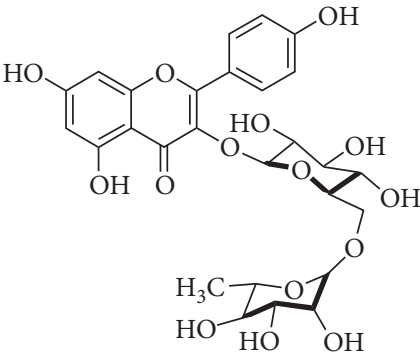

Kaempferol 3-O-rutinoside (3)<smiles>O=c1c(O)c(-c2ccc(O)cc2)oc2cc(O)cc(O)c12</smiles>

Kaempferol (6)

Luteolin (7)

Figure 7: Common hepatoprotective flavonoids identified and isolated from A. spinosus, C. tinctorius, C. fistula, and T. purpurea. 
The flavonoid-rich fraction of another hepatoprotective plant (HP) T. purpurea containing quercetin (5), coumarins, flavonoids, and flavanones protects against rat hepatotoxicity induced by $\mathrm{CCl}_{4}$ at a dose of $100 \mathrm{mg} / \mathrm{kg}$ dose via reduction of the elevated level of serum SGOT, SGPT, ALP, and bilirubin (Figure 5) [162]. The rutin (1), catechin (4), quercetin (5), kamferol (6), and luteolin (7) flavonoids have also been isolated from different crude extracts of $A$. spinosus, C. tinctorius, C. fistula, and T. purpurea, which further supports their reported and traditional liver-protective activity (Figure 7) [163-166]. Flavonoids and phenolics such as myricetin (8), quercetin 3-O-xylosyl-(1 $\longrightarrow 2$ ) rhamnoside (9), ellagic acid rahmnoside (10), and rosmarinic acid (11) from $S$. jambos leaf extracts have been identified using HPLCPDA-MS/MS that showed promising liver-protective activity in $\mathrm{CCl}_{4}$-induced liver injury rats (Figure 8) [167]. The extract at a dose of $200 \mathrm{mg} / \mathrm{kg}$ reduced the levels of liver markers and increased antioxidant enzymes GSH and SOD. Furthermore, in vitro assay confirmed that pretreatment with the extract inhibited ROS production via prevention of $\mathrm{p} 38$ and its target MAPKAP kinase-2- (MAPKAPK-2-) activated signaling cascade in sodium arsenite-induced oxidative stress of HepG2 hepatocytes [167]. The p38 and MAPKAPK-2 are mitogenactivated protein kinase (MAPK) family proteins that regulate the production of inflammatory cytokines as well as play a vital role in hepatoprotective function by restricting ROS accumulation in the liver during oxidative stress [168]. Interestingly, natural flavonoids have already showed their liverprotective activity against oxidative stress via the MAPK signaling pathway [169].

Gallic acid (12) and its derivative methyl gallate (13) are the common plant phenolics that have been isolated from the BHP of Lawsonia inermis and showed significant hepatoprotective effect at an IP (intraperitoneal) dose of $294 \mu \mathrm{M} / \mathrm{kg}$ gallic acid (GA) in $\mathrm{CCl}_{4}$-intoxicated rats (Figure 9) [170]. The study did not reveal any molecular mechanism of GA but demonstrated that the protective effect was observed by lowered serum biochemical parameters, a significant reduction of hepatic ROS, and an increase in antioxidant enzymes, as well as normalized hepatocellular necrosis, vacuolization, and inflammatory cell infiltration. Another report also demonstrated that GA has the ability to protect against liver toxicity by enhancing enzymatic antioxidant systems and reduce hepatic inflammation via inducing Nrf2-mediated antioxidant enzymes and attenuating the inflammatory mediators COX-2 through the NF- $\kappa \mathrm{B}$ inhibition pathway [171]. Another plant hepatoprotective phenol, chebulic acid (14), was isolated (as a mixture with neochebulic acid (15)) from Terminilia chebula that showed reduction of tert-butyl hydroperoxide- (t-BHP-) induced ROS and cell cytotoxicity and the ratio of GSSH with GSH in isolated rat hepatocytes in vitro at a dose of $280 \mu \mathrm{M} / \mathrm{mL}$ (Figure 9) [172]. A recent in vitro study conducted by Jung et al. confirmed that chebulic acid can dose dependently $(0.4$, 2 and $2 \mu \mathrm{M}$ ) enhance phosphorylation of MAPK and protect hepatocytes against t-BHP-induced oxidative stress via controlling the activation of $\mathrm{Nrf} 2$ and its related cytoprotective enzymes including $\mathrm{HO}-1$ and gamma-glutamate cysteine ligase $(\gamma$-GCL) [173].
3.3.2. Terpenoids. Among the terpenoid class of NPSMs, a number of diterpene type of compounds have been isolated from BHP that showed potential hepatoprotective activity (Table 3). The diterpene lactone, andrographolide (16), is a well-known natural molecule isolated from $A$. paniculata Nees. (Kalmegh) that has been used as a key ingredient in a variety of polyherbal formulations to treat hepatitis, hepatic dysfunction, and hepatic regeneration, as well as a liver tonic, in Bangladesh and the Indian subcontinent [174]. Literature study demonstrated that andrographolide isolated from $A$. paniculata showed liver protection against alcoholic (177-1427 $\mu \mathrm{M} / \mathrm{kg}$, ip)/nonalcoholic (143 $\mu \mathrm{M} / \mathrm{kg}, \mathrm{p} . \mathrm{o})$ fatty liver or APAP $(2-34 \mu \mathrm{M} / \mathrm{kg}, \mathrm{p} . \mathrm{o}) / \mathrm{CCl} 4(286 \mu \mathrm{M} / \mathrm{kg}$, ip)induced hepatotoxicity (Table 3 ).

The hepatoprotective activity of andrographolide observed via liver regeneration prevents degradation/necrosis of liver cells, upregulates antioxidant enzymes, and inhibits lipid peroxidation [175-178]. Improvement of hepatic biliary function and insulin secretion in hepatocytes has an impact on liver regeneration, prevention of degradation of hepatocytes, or hepatic dysfunction $[179,180]$. Interestingly, the protective effect of andrographolide via liver regeneration or prevention of necrosis of liver cells has a close relation with its choleretic effect as well as stimulation of insulin secretion in hepatocytes [181, 182]. It is also reported that andrographolide normalized the hepatic fatty changes, multifocal mononuclear cell infiltration, and hepatocyte ballooning in high-fat-diet fatty liver as a function of its protective effect [183]. Andrographolide derivatives including isoandrographolide (17), neoandrographolide (18), 3,19-acetonylidene andrographolide (19), and andrographiside (20) have also been reported to possesses liverprotective effects as andrographolide and even sometimes more potent than andrographolide (Figure 10). Another hepatoprotective study confirmed that the glucoside group with andrographolide (i.e., andrographiside (20)) might act as a strong antioxidant than andrographolide itself or neoandrographolide in which andographiside significantly inhibit lipid peroxidation, GSH depletion, and enzymatic leakage of SGPT and ALP compared to andrographolide and neoandrographolide alone [177].

Another new diterpene named portulene (21) along with known compounds lupeol (22), $\beta$-sitosterol (23), and daucosterol (24) has been isolated from the extract of Portulaca oleracea that showed a liver-protective effect at a dose $10-50 \mathrm{mg} / \mathrm{kg}$ against $\mathrm{CCl}_{4}$-induced hepatic injury in rats via the inhibition of leakage of liver enzymes and biomarkers (Figure 11) [184]. The hepatoprotective activity of these phytoconstituents is supported by a previous study of lupeol and $\beta$-sitosterol that showed liver-protective activity via antioxidant and anti-inflammatory mechanisms $[185,186]$.

A number of triterpene acids, namely, betulinic (25), oleanolic (26), ursolic (27), alphitolic (28), 3-epimaslinic (29), and euscaphic acid (30), have been isolated from triterpene-rich $\mathrm{CH}_{2} \mathrm{Cl}_{2}$ hairy root extract of Ocumum basilicum L. that showed hepatoprotective activity in $\mathrm{CCl}_{4^{-}}$ induced hepatotoxicity in experimental animals (Figure 12) [187]. The isolated triterpene acids also dose-dependently 


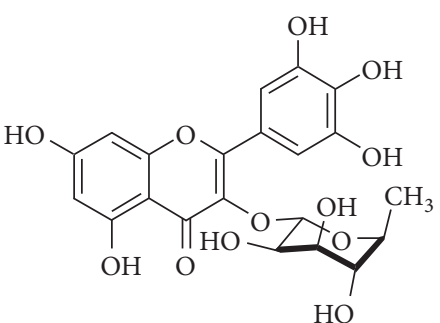

Myrecetin (8)

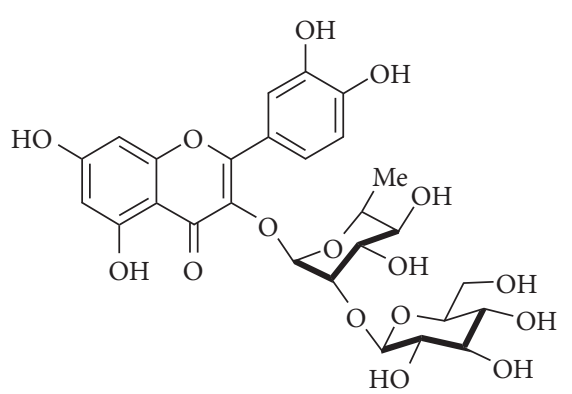

Quercetin 3-O-xylosyl-(1 $\rightarrow$ 2)rhamnoside (9)<smiles>CC1O[C@@H](OC2=C(O)C=c3c(=O)oc4c5c2oc(=O)c(c35)C=C(O)C=4O)C(O)[C@H](O)[C@H]1O</smiles>

Ellagic acid rhamnoside (10)<smiles>O=C(/C=C/c1ccc(O)c(O)c1)CC(Cc1ccc(O)c(O)c1)C(=O)O</smiles>

Rosmarinic acid (11)

Figure 8: Hepatoprotective flavonoids and phenolics identified from S. jambos.<smiles>O=C(O)c1cc(O)c(O)c(O)c1</smiles>

Gallic acid (12)<smiles>COC(O)c1cc(O)c(O)c(O)c1</smiles>

Methyl gallate (13)<smiles>O=C(O)C[C@@H](O)[C@H]1c2c(cc(O)c(O)c2O)C(=O)O[C@H]1C(=O)O</smiles>

Neochebulic acid (15)
FIgURE 9: Hepatoprotective phenolics isolated from $L$. inermis and T. chebula.

(0.1-5 $\mathrm{mg} / \mathrm{mL})$ ameliorate liver oxidative stress by inhibition of lipid peroxidation in iron/ascorbate-induced lipid peroxidation in liver homogenate [187]. Interestingly, it is reported that oleanane- and ursane-type triterpenoids are the two largest groups of phytoconstituents that possess noticeable hepatoprotective activities including oleanolic acid and ursolic acid which have been used to treat liver diseases for years in China [188]. The protective effect of oleanolic acid (26) against acute liver injury involved its anti-inflammatory activity thorough the activation of peroxisome proliferator-activated receptor alpha (PPAR $\alpha)$ and downregulation of the c-Jun $\mathrm{NH}_{2}$-terminal kinase (JNK) signaling pathway [189]. The antioxidant effect of ursolic acid (27) in the prevention of liver injury involved the modulation of MAPKs and the NF- $\kappa \mathrm{B}$ signaling pathway [190]. On the other hand, betulinic acid (25) has the ability to prevent hepatic inflammation and fibrosis via the suppression of the TLR4/MyD88/NF- $\kappa$ B signaling pathway [191].

Hepatitis virus (HBV, HAV, and $\mathrm{HCV}$ ) causes a severe and frequently transmittable disease of the liver, and among these, HBV was the most common one that infected millions of people worldwide. The extract of O. basilicum L. was reported to be active against viral hepatitis (HAV) [192]. There was no confirmation about the active principle responsible for the antihepatitis activity of $O$. basilicum L.; however, the triterpene acids, especially betulinic acid, ursolic acid, and oleanolic acid (Figure 12), have been reported to be active against viral hepatitis. The betulinic acid protects mice liver by inhibiting $\mathrm{HBV}$ replication in hepatocytes of $\mathrm{HBV}$ transgenic mice through downregulation of SOD-2 expression as well as inhibition of ROS production and mitochondrial dysfunction [193]. Betulinic acid also inhibits HCV replication in cultured cells, and the molecular mechanism reported that it might downregulate $\mathrm{HCV}$-induced $\mathrm{COX}-2$ expression through the inhibition of phosphorylation of NF- $\kappa \mathrm{B}$ and ERK1/2 of the MAPK signaling pathway [194]. The antihepatitis potential of ursolic acid and oleanolic acid was also reported against $\mathrm{HBV}$ and $\mathrm{HCV}$ viruses. The anti-HBV activity of ursolic acid might be involved in blocking the pathological effects of HBV which confirmed by the study in which ursolic acid reduced the migratory process and matrix metalloproteinase- 3 secretion in $\mathrm{HBV}$-X protein-transactivated cell lineages [195], while the anti-HCV activity of oleanolic acid and ursolic acid was observed via inhibition of of viral NS5B RNA-dependent RNA polymerase (RdRp) activity, an enzyme responsible for HCV RNA replication [196].

Cucurbitane-type triterpene glycosides are another class of hepatoprotective triterpenoids found in Momordica charantea L. which has been used as a popular vegetable and traditional 
<smiles>C=C1CCC2[C@](C)(CC[C@@H](O)[C@@]2(C)CO)[C@H]1CC=C1C(=O)OC[C@H]1O</smiles>

Andrographolide (16)<smiles>C[C@]12CCC3[C@](C)(CC[C@@H](O)[C@@]3(C)CO)C1C[C@H](C1=CCOC1=O)O2</smiles>

Isoandrographolide (17)<smiles>C=C1CCC2[C@](C)(COC)CCC[C@]2(C)[C@@H]1CCC1=CCOC1=O</smiles>

Neoandrographolide (18)<smiles>C=C1CCC2[C@@]3(C)COC(C)(C)O[C@H]3CC[C@]2(C)[C@@H]1CC=C1C(=O)OC[C@H]1O</smiles>

3, 19-acetonylidene andrographolide (19)<smiles>C=C1CCC2[C@](C)(COCl)[C@H](O)CC[C@]2(C)[C@@H]1C/C=C1/C(=O)OC[C@H]1O</smiles>

Andrographiside (20)

FIgURE 10: Hepatoprotective diterpene lactone isolated from A. paniculata.<smiles>C[C@H]1CC[C@]2(C(=O)O)C(CCC[C@@H]2C)[C@H]1CC/C(=C\CO)CO</smiles>

Portulene (21)

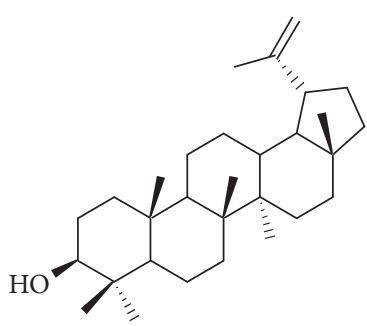

Lupeol (22)

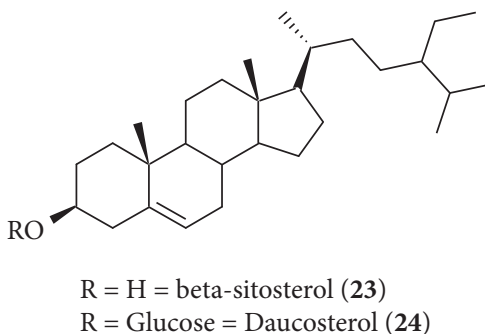

$\mathrm{R}=\mathrm{H}=$ beta-sitosterol (23)

$\mathrm{R}=$ Glucose $=$ Daucosterol (24)

FIgURE 11: Hepatoprotective phytoconstituents isolated from P. oleracea L.

medicine to treat liver diseases. A recent study isolated a number of cucurbitane-type triterpene glycosides from the fruits of M. charantea including three new furpyronecucurbitane A (31), goyaglycoside I (32), and charantagenin F (33) along with ten known cucurbitane (34-43) (Figure 13) [197]. All the isolated compounds were evaluated for antihepatic fibrosis activity against murine hepatic stellate cells (t-HSC/Cl-6) and antihepatoma activity against liver cancer cell lines (HepG2 and Hep3B), and karaviloside III (41) was found as the most potent molecule with an $\mathrm{IC}_{50}$ 3.74-17 $\mu \mathrm{M}$ [197]. Previously, two norcucurbitane-type triterpenoids named pentanorcucurbitacin B (44) and 25,26,27trinorcucurbit-5-ene-3, 7, 23-trione (45) were isolated from the same plant that showed cytoprotective potential against t-BHPinduced injury on HepG2 cells with $\mathrm{IC}_{50} 5-10 \mathrm{mM}$ and was comparable to silybin (Figure 13) [198].
3.3.3. Curcuminoids. Curcuminoids are diarylheptanoids which belongs to natural phenolic compounds, and curcumin (46) (60-70\%), demethoxycurcumin (20-27\%) (47), and bisdemethoxycurcumin (10-15\%) (48) are the major curcuminoids present in turmeric C. longa (Figure 14) [199]. Curcumin (46), chemically known as (1E-6E)-1,7-bis (4hydroxy-3-methoxy phenyl)-1,6-heptadiene-3,5-dione, is the major bioactive compound isolated from turmeric. Curcumin reported to possess various pharmacological actions including hepatoprotective and antioxidant properties [200]. The hepatoprotective effect of curcumin has been well established via a number of in vitro and in vivo investigations (Table 3). The hepatoprotective activity of curcumin was due to its multitarget function. Curcumin (136-544 $\mu \mathrm{M} / \mathrm{kg}$. p.o) ameliorated liver injury in animals induced by $\mathrm{APAP} / \mathrm{CCl}_{4}$ or lindane through upregulation of 

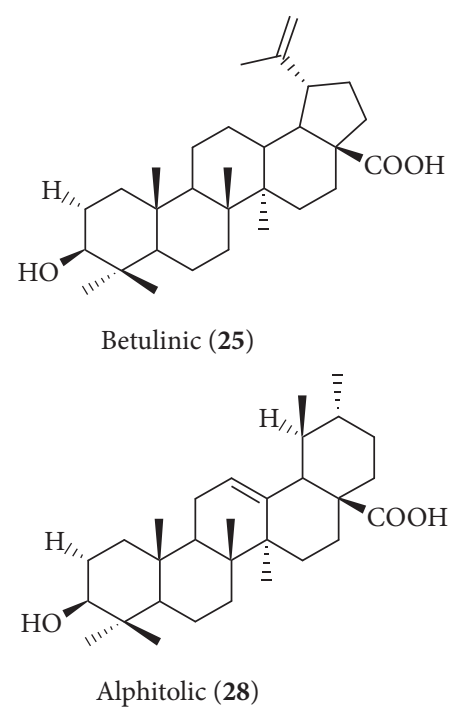
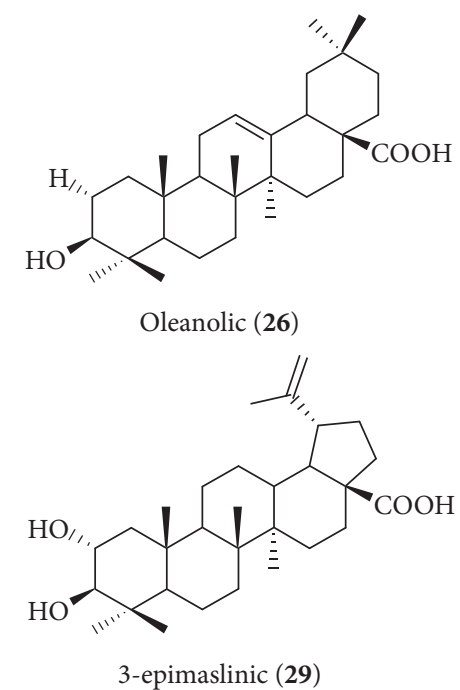
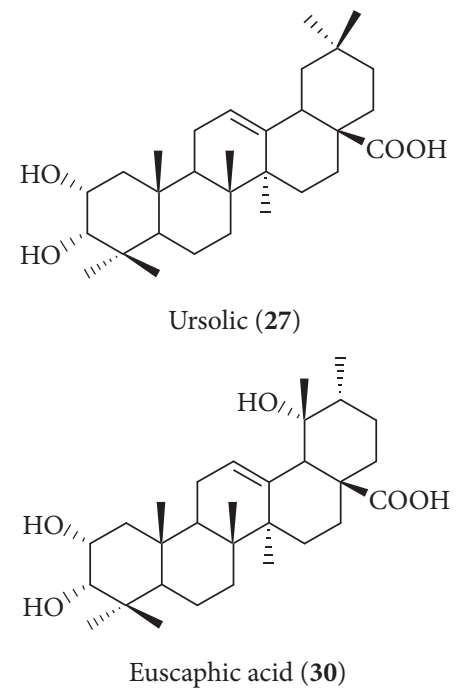

FIGURE 12: Hepatoprotective triterpene acids isolated from O. basilicum.

the antioxidant defense mechanism and restored the elevated liver markers via inhibition of hepatic cell degradation and leakage and inhibition of lipid peroxidation [201-203]. Alfatoxin B1-induced hepatotoxicity involved LPO and oxidative DNA damage of liver cells. The antioxidant potential of curcumin protected against aflatoxin B1-induced liver toxicity by restoring the elevated levels of serum marker enzymes and LPO and elevating the antioxidant enzyme levels as well as reduced excretion of DNA adducts $[204,205]$. The molecular mechanism of hepatoprotection of curcumin was believed to link with reduction of oxidative stress via the antioxidant activity and activation of the Nrf2/ Keap1/ARE pathway and its related phase II detoxifying/ antioxidant enzymes including $\mathrm{HO}-1$ and $\mathrm{NAD}(\mathrm{P}) \mathrm{H}$ :quinone oxidoreductase-1 (NQO 1) (Figure 6) [206, 207]. Moreover, curcumin protects CYP 2E1 enzymatic activity against mercuric chloride- $\left(\mathrm{HgCl}_{2}-\right)$ induced hepatotoxicity and oxidative stress in rats [123], which is supported by a previous study of curcumin that it induces peroxiredoxin-6 (Prx-6) and downregulates CYP2E1 as well as Prx1 expression in diet-induced oxidative stress [208]. It is believed that cross regulation of Prx1 and Prx6 is likely to participate in cellular defense against the development of hepatitis. The anti-inflammatory responses of curcumin that protected liver fibrosis induced by dimethylnitrosamine (DMN) were observed along with the reduction of electrical conductivity and leaking of liver biomarkers [209]. Inhibition of the hepatic NF- $\kappa \mathrm{B}$ signaling pathway is reported to be a potential pathway to attenuate the inflammatory process in the liver, and a number of investigations confirmed the downregulatory property of curcumin to hepatic expression of NF- $\kappa \mathrm{B}$ and its downstream targets $[210,211]$. Other reports also showed that curcumin protects against hepatic fibrogenesis through the inhibition of the expression of tolllike receptor 2 and 4 (TLR2 and TLR4) and their ligand molecule high-mobility group protein box-1 (HMGB1) in $\mathrm{CCl}_{4}$-indcued rat hepatic fibrogenesis [212]. Interestingly, all TLR signaling pathways have a close relation with NF- $\kappa \mathrm{B}$ activation which regulate the expression of inflammatory cytokine genes [213]. Furthermore, curcumin could ameliorate hepatic inflammation and fibrosis by enhancing the degradation of damaged hepatic cells via apoptosis through the inhibition of the expression of proapoptotic genes Bax, Bcl-2 mRNA, and caspase-3 as well as inducing antiapoptotic genes $\mathrm{Bcl}-\mathrm{xL}$ and upregulating p53 protein expression in APAP- or TAA-induced hepatotoxicity (Figure 6) [214-216].

Curcumin was also a potential natural hepatoprotectve molecule that is effective in viral hepatitis and proved to be active as a host-targeted therapy for HBV infection. Mouler et al. showed that curcumin protects HepG2215 cells from $\mathrm{HBV}$ infection via the inhibition of $\mathrm{HBV}$ gene expression and replication. The molecular mechanism of the inhibition of replication involved downregulation of peroxisome proliferator-activated receptor-gamma coactivator-1alpha (PGC-1 $\alpha$ ), which is a starvation-induced protein that has a role in the initiation of the gluconeogenesis cascade and may robustly coactivate HBV transcription [217].

3.3.4. Aromatic Compounds. A study reported that C. longa yielded aromatic compounds ar-turmerone (49) and its derivatives $\alpha$-tumerone (50) and $\beta$-tumerone (51) which showed liver-protective activity $(0.5 \%$ with diet) against d-galactosamine-induced liver toxicity in rats via suppressing the increase of LDB, ALT, and AST levels (Figure 14) [218]. However, the liver-protective mechanism of sesquiterpenes in turmeric was not clear and might be different from that of curcuminoids [219].

Aloe emodin (52), chemically known as 1,8-dihydroxy3-hydroxyl-methylanthraquinone, is an anthraquinone derivative and one of the main bioactive components of Aloe vera (Figure 15). Literature study demonstrated that the anthraquinone derivative aloe emodin possesses hepatoprotective potential both in vivo and in vitro. Arosio et al. showed that pretreatment of aloe emodin $(185 \mu \mathrm{M} / \mathrm{kg}$, i.p.) 


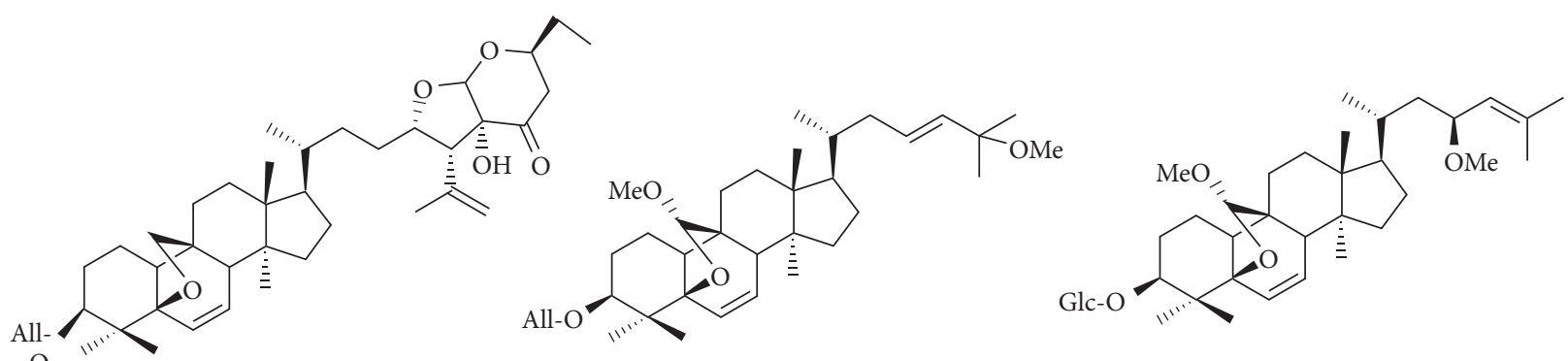

$\mathrm{O}$

Furpyronecucurbitane A (31)

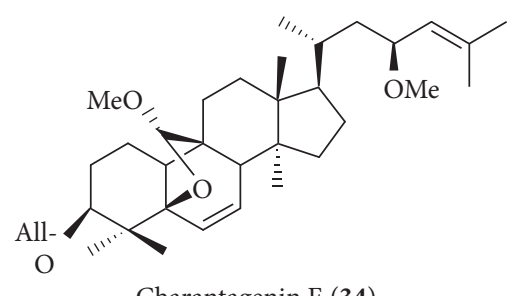

Charantagenin E (34)

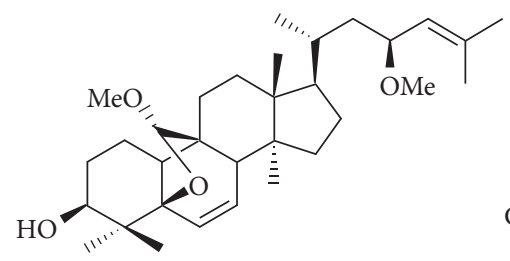

(19R, 23S)-5b, 19-epoxy-19, 23dimethoxycucurbita-6, 24-dien-3b-ol (35)

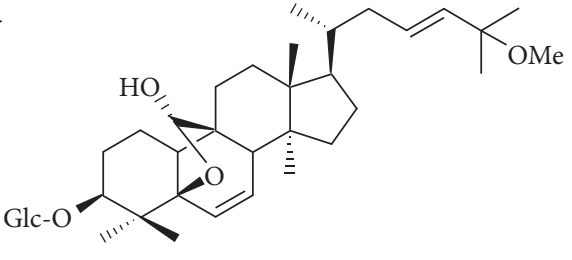

Charantoside D (36)

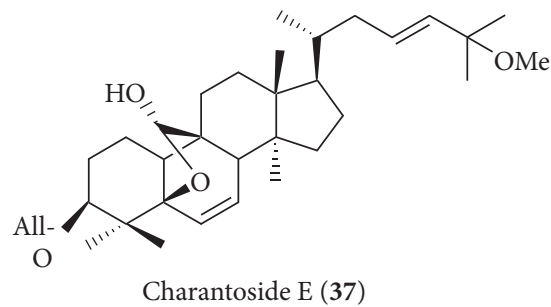

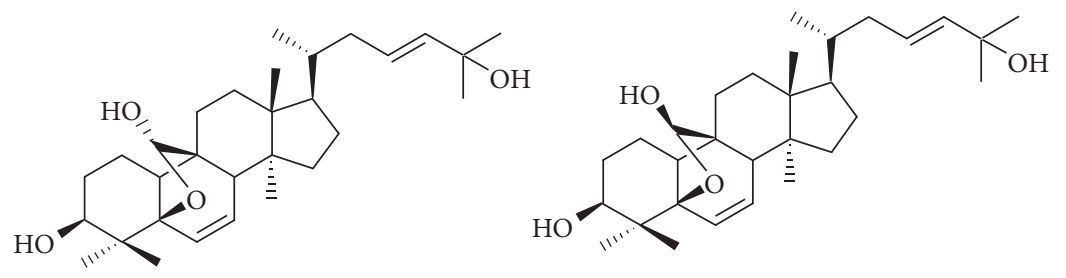

19(R)-5b, 19-epoxycucurbita-6, 23-diene-3b, 19, 25-triol (38)

19(S)-5b, 19-epoxycucurbita-6, 23-diene-3b, 19, 25-triol (39)

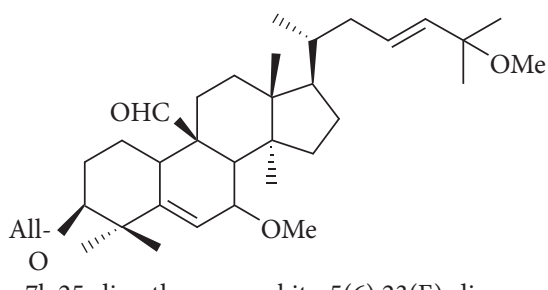

7b,25-dimethoxycucurbita-5(6),23(E)-di en-19-al3-O-b-D-allopyranoside (40)

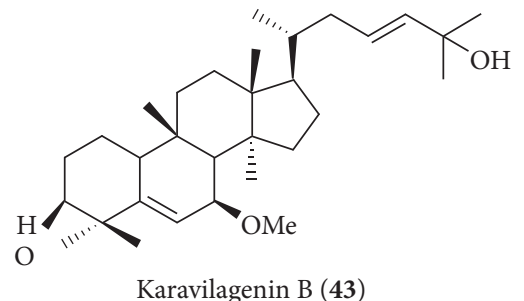

Karavilagenin B (43)

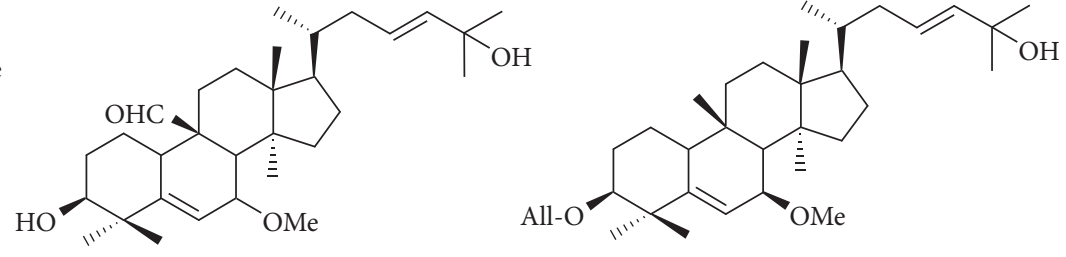

7b,25-dimethoxycucurbita5(6),2 3(E)-dien-19-al (41)<smiles>C[C@H](C(=O)O)[C@H]1CC[C@]2(C)C3C(=O)C=C4C(CCC(=O)C4(C)C)[C@@]3(C)CC[C@]12C</smiles>

Pentanorcucurbitacin B (44)<smiles>CC(=O)C[C@H](C)[C@H]1CC[C@]2(C)[C@@H]3C(=O)C=C4[C@@H](CCC(=O)C4(C)C)[C@@]3(C)CC[C@]12C</smiles>

25, 26, 27-trinorcucurbit-5-ene-3, 7, 23-trione (45)

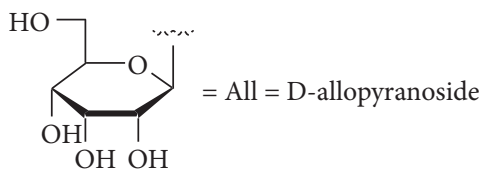<smiles>CC1(C)OC(CO)C(O)C(O)C1O</smiles>

FIGURE 13: Hepatoprotective cucurbitane-type triterpenoids isolated from M. charantea. 
<smiles>COc1cc(/C=C/C(=O)CC(=O)/C=C/c2ccc(O)c(OC)c2)ccc1O</smiles>

Curcumin (46)<smiles>COc1cc(/C=C/C(=O)CC(=O)/C=C/c2ccc(O)cc2)ccc1O</smiles>

Demethoxycurcumin (47)<smiles>O=C(/C=C/c1ccc(O)cc1)CC(=O)/C=C/c1ccc(O)cc1</smiles>

Bisdemethoxycurcumin (48)

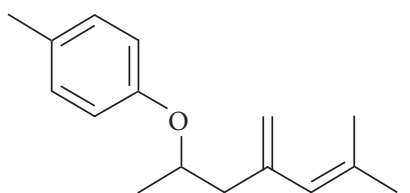

ar-Tumerone (49)<smiles>C=C(C=C(C)C)CC(C)OC1C=CC(C)=CC1</smiles>

alpha-Tumerone (50)

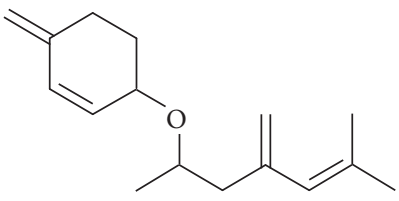

beta-Tumerone (51)

FIgURE 14: Hepatoprotective curcuminoids and sesquiterpenes isolated from C. longa.

protects against $\mathrm{CCl}_{4}$-induced acute liver damage via the inhibition of lipid peroxidation subsequently reduced to free-radical production [220]. The treatment of aloe emodin also ameliorated the inflammatory lesions in liver cells and ultimately reduced the leakage of liver markers L-aspartate2-oxoglutate-aminotransferase in serum via the inhibition of proinflammatory cytokines TNF- $\alpha$ mRNA expression [220]. Later, Woo et al. demonstrated that aloe emodin can also inhibit the activation and proliferation of hepatic stellate in vitro by the reduction of DNA synthesis and inhibition of type I collagen production and $\mathrm{sm}-\alpha$ (smooth muscle $\alpha$-actin) expression $(0.004-0.04 \mu \mathrm{M} / \mathrm{mL})$, a key liver cell that has an essential role in the pathogenesis of liver fibrosis [221].

Aloin (53) is another anthraquinone glycoside that has been reported to isolate from different Aloe species including A. vera (Figure 15) [222]. Aloin protects against chronic alcoholic liver injury at a dose of $24-72 \mu \mathrm{M} / \mathrm{kg}$ by attenuating lipid accumulation, oxidative stress, and LPS-induced inflammatory response as well as significant reduction of hepatic mRNA expression of CYP2E1 [223]. The molecular mechanism of the reduction of lipid accumulation was observed by the activation of AMP-activated protein kinase- $\alpha 2$ (AMPK- $\alpha 2$ ) and downregulation of sterol regulatory element-binding protein-1c (SREBP-1c) expression that has a role in the balance between lipid synthesis and fatty acid oxidation/lipolysis. A recent interesting study conducted by Jung et al. reported the protective effect of aloin against retinal injury associated with liver failure by normalization of Kir4.1 and aquaporin-4 channels in TAA-induced hepatic retinopathy [224].

Embelin (54), chemically known as 2,5-dihydroxy-3undecyl-1,4-benzoquinone, is a natural para-benzoquinone derivative derived from the BHP of Embelia ribes that possesses a wide range of medicinal activities including hepaprotective activity (Figure 15) [225]. Sreepriya and Bali investigated the protective effect of embolin $(170 \mu \mathrm{M} / \mathrm{kg})$ against hepatocarcinogenesis induced by $\mathrm{N}$-nitrosodiethylamine- (DENA-) initiated and phenobarbital- (PB-) promoted hepatocarcinogenesis in the rat model. The results showed that embolin has the ability to prevent leakage of hepatic biomarkers, inhibit lipid peroxidation, upregulate antioxidant defense, and reduce the percentage of hepatic hyper plastic nodule incidence and hypoproteinemia in DENA-/PB-treated hepatocarcinogenesis rats [226, 227]. The antioxidant activity of embelin was further confirmed to involve in the protection of liver toxicity in rats [228]. The molecular mechanism of hepatoprotective activity of embelin was not clear; however, a previous study showed that embelin has the ability to modulate Nrf-2/HO-1, MAPK/NF- $\kappa \mathrm{B}, \mathrm{p} 53$, and STAT3 signaling pathways to regulate cellular oxidative stress, inflammatory response, and apoptosis that might be responsible for its protective effect against hepatotoxin-induced liver damage [229-231].

3.3.5. Fatty Acids. Natural fatty acids are common phytoconstituents in various functional foods that possess different bioactivities and have been used as a supplement to treat different diseases. trans-Tetracos-15-enoic acid (TCA) (55), a monounsaturated fatty acid, was derived from bioactivity-guided isolation of the dried aerial parts of Indigofera tinctorial Linn. that possess hepatoprotective activity in $\mathrm{CCl}_{4}$ - and APAP-induced liver toxicity in the rat and mice model (Figure 15) [232]. The study demonstrated 
<smiles>O=C1c2cc(CO)cc(O)c2C(=O)c2cccc(O)c21</smiles>

Aloe emodin (52)

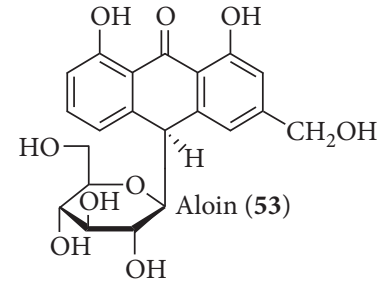

(a)

$\mathrm{CH}_{3}-\left(\mathrm{CH}_{2}\right)_{7}-\mathrm{CH}=\mathrm{CH}-\left(\mathrm{CH}_{2}\right)_{11}-\mathrm{CH}_{2}-\mathrm{CH}_{2}-\mathrm{COOH}$

trans-Tetracos-15-enoic acid (55)

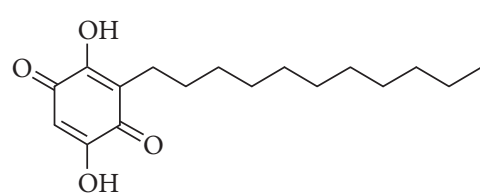

Embelin (54)

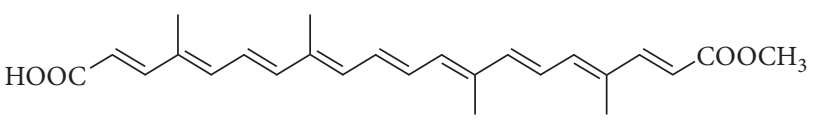

Bixin (56)

(d)

FIgURE 15: Hepatoprotective compounds isolated from Bangladeshi plants. (a) Anthraquinone derivative aloe emodin and aloin from A. vera; (b) para-benzoquinone derivative embelin from of E. ribes; (c) fatty acid TCA from of $I$. tinctora; and (d) carotenoid derivative bixin from B. orellana.

that TCA has both preventive and curative potential (34-273 $\mu \mathrm{M} / \mathrm{kg}$, p.o) as a hepatoprotective agent and it was comparable to that of the known protective agent silymarin. Pre- and posttreatment of TCA showed significant dose-dependent $(12.5-100 \mathrm{mg} / \mathrm{kg}, \mathrm{p} . \mathrm{o})$ restoration of elevated serum level of liver marker enzymes and inhibited lipid peroxidation as well as upregulated antioxidant enzyme GSH.

3.3.6. Carotenoids. A carotenoid derivative apocarotenoid, known as bixin (56), has been isolated from $B$. orellana L. seeds that possess various pharmacological properties (Figure 15) [233]. Pinzón-García et al. reported that bixin $(127 \mu \mathrm{M} / \mathrm{kg})$ and bixin: $\beta$-cyclodextrin combination could ameliorate nonalcoholic fatty liver steatosis and its associated obesity, hyperglycemia, and hyperlipidemic condition in the high-fat-diet C57BL/6 mice model [234]. The molecular mechanism of its hepatoprotective activity was not clear, but the study demonstrated the hepatoprotective effect of bixin involved the improvement of lipid profile and inhibition of fat accumulation in the liver.

3.3.7. Polysaccharide. Polysaccharide (57) is another main bioactive constituent in $A$. vera gel that has been reported to possess a number of biological activities including liver protective activity [235]. Cui et al. demonstrated the supplementation of polysaccharide extracted from $A$. vera against alcohol liver disease (ALD) in a chronic alcoholfeeding mouse model [236]. The hepatoprotective effect of polysaccharide involved with its antioxidant activity increased lipolysis and anti-inflammatory response. The molecular mechanism of lipolysis by polysaccharide was observed by significant upregulation of hepatic expression of lipolytic genes AMPK- $\alpha 2$ and $\operatorname{PPAR} \alpha$; on the other hand, alcohol-induced inflammation was protected through downregulation of TLR-4 and MyD88 and upregulation of $\mathrm{I} \kappa \mathrm{B}-\alpha$ (nuclear factor of kappa light polypeptide gene enhancer in B-cell inhibitor, alpha) [236].

\section{Challenges with Bangladeshi Hepatoprotective Plants}

Based on ethnomedicinal evidence and practice, plant extracts and their active constituents have the potential to treat liver diseases. This review summarized Bangladeshi plants that have been traditionally used for the treatment of liver diseases, namely, jaundice, ascites, liver cirrhosis, hepatitis, liver enlargement, inflammatory liver, sclerosis of the liver, and other ailments. Literature survey revealed that a number of these plants have been reported to ameliorate liver toxicity or injury induced by various chemicals, drugs, and/or foods, in both in vitro and in vivo settings. Generally, people from rural areas are largely dependent on traditional herbal medicine for their primary healthcare needs, including treatment of liver problem, because of traditional evidence of their effectiveness and safety, as well as lack of access to modern drugs. However, the major challenges of these ethnomedicinal herbal treatments are lack of standardization, quality, efficacy, and taxonomic documentation and toxic effects. A number of BHPs underwent pharmacological and phytochemical analysis in terms of their hepatoprotective activity, although a major portion of these plants is still either underexplored or unexplored. Therefore, there is an urgent need for preclinical and clinical studies of these plants to study their efficacy in the treatment of liver diseases. The resolution for these challenges needs rigorous chemical and clinical research to confirm the potentials of these BHPs and identify their active constituents in the treatment of different liver diseases. Since large percentages of people with liver diseases use botanicals as prophylactics all over the world, a substantial effort is being made in recent years to develop plant-based therapeutics with a novel mechanism of action.

Finally, Bangladesh is located at the juncture of the IndoMalayan and Indo-China subregion of tropical South-East Asia. With this unique geographical location, the land of Bangladesh (Figure 3) is very fertile for plant growth. About 2.5 million hectares of land is covered by forest which is approximately $17.5 \%$ of the total area. Since Bangladesh is in the forefront of global climate change and very susceptible to 
natural calamities, pollution, and man-made deforestation, these valuable plant resources are already under threat. It is important for governmental and nongovernmental organizations to come forward and preserve these precious plant resources so that proper scientific evaluation and documentation can be carried out before they perish.

\section{Conclusions}

This review summarized 88 Bangladeshi ethnomedicinal plants that have been traditionally used in the treatment of different liver problems, and among these, 64 species have been reported to have hepatoprotective activity either in vivo or in vitro, and 17 species underwent further phytochemical analysis to identify active constituents. Literature review revealed that A. vera, A. paniculata, C. fistula, C. longa, and $B$. diffusa with their active compounds, namely, andrographolide (16), aloe emodin (52), curcumin (46), karaviloside III (41), catechin (4), chebulic acid (14), and gallic acid (12) were the most promising lead molecules, which have the potential for further development for hepatoprotective drug discovery. The hepatoprotective activity of these plants was reported to act through different mechanisms, including enhancing regeneration of hepatocytes or decreasing degradation/necrosis of liver cells and subsequently reducing leakage or restoring elevated level of serum liver biomarkers, as well as inhibiting lipid peroxidation and upregulating hepatic antioxidant enzyme activities. Induction of apoptosis of injured hepatocytes and protection from cytochrome enzymes were also reported by the liver-protective agents. The molecular mechanism of activity of constituents varied from molecule to molecule, but the activation of Nrf2/HO-1 and inhibition of $\mathrm{p} 38$ MAPKs and TLR4/MyD88/NF- $\kappa \mathrm{B}$ were the most common pathways revealed from literature survey. Although a number of plants with similar phytoconstituents have also been explored, a good number of BHPs are still unexplored in terms of isolation of active principle(s), as well as scientific validation of their traditional claim as a hepatoprotective agent. Finally, Bangladeshi plants represent a valuable resource for the development of therapeutics; therefore, well-designed and controlled clinical trials need to be executed on traditionally used BHPs, together with the chemical profiling of actives or markers which will establish the efficacy and safety of botanical medicine for liver diseases.

\section{Abbreviation}

$\begin{array}{ll}\text { AH: } & \text { Aniline hydroxylase } \\ \text { AMPK- } \alpha 2: & \text { AMP-activated protein kinase- } \alpha 2 \\ \text { AND: } & \text { Amidopyrine-N-demethylase } \\ \text { APAP: } & \text { Paracetamol } \\ \text { ALD: } & \text { Alcohol liver disease } \\ \text { ALP: } & \text { Alkaline phosphatase } \\ \text { AQ: } & \text { Aqueous } \\ \text { ARE: } & \text { Antioxidant response element } \\ \text { AST: } & \text { Aspartate aminotransferase } \\ \text { BHPs: } & \text { Bangladeshi hepatoprotective plants } \\ \text { BHC: } & \text { Hexachlorocyclohexane }\end{array}$

$\begin{array}{ll}\text { t-BHP: } & \text { tert-Butyl hydroperoxide } \\ \text { BSP: } & \text { Bromosulphalein } \\ \text { CAT: } & \text { Catalase } \\ \text { CCl }_{4}: & \text { Carbontetrachloride } \\ \text { COX-2: } & \text { Cyclooxygenase-2 } \\ \text { CYP2E1: } & \text { Cytochrome P450-2E1 } \\ \text { DEN: } & \text { Diethyl nitrosamine } \\ \text { DENA: } & \text { N-nitrosodiethylamine } \\ \text { DMN: } & \text { Dimethylnitrosamine } \\ \text { EtOH: } & \text { Ethanol } \\ \text { FeSO }: & \text { Ferrus sulphate } \\ \text { GA: } & \text { Gallic acid } \\ \gamma \text {-GCL: } & \text { Gamma-glutamate cysteine ligase } \\ \text { GNH }: & \text { D (+)-galactosamine } \\ \text { GSH: } & \text { Glutathione } \\ \text { GPx: } & \text { Glutathione peroxidase } \\ \text { GRD: } & \text { Glutathione reductase } \\ \text { GST: } & \text { Glutathione s-transferease } \\ \gamma-G T: & \text { Gamma-glutamyl transferase } \\ \text { HAV: } & \text { Hepatitis A virus } \\ \text { HBV: } & \text { Hepatitis B virus } \\ \text { HCV: } & \text { Hepatitis C virus } \\ \text { HEV: } & \text { Hepatitis E virus } \\ \text { HgCl }: & \text { Mercuric chloride } \\ \text { HMGB1: } & \text { High-mobility group protein box-1 } \\ \text { HO-1: } & \text { Heme oxygenase-1 } \\ \text { HP: } & \text { Hepatoprotective plant } \\ \text { t-HSC/Cl- }: & \text { Murne hepatic stellate cells }\end{array}$

t-HSC/Cl-6: Murine hepatic stellate cells

I $\kappa$ B $-\alpha$ : Nuclear factor of kappa light polypeptide gene enhancer in B-cell inhibitor, alpha

IL-6: $\quad$ Interleukin -6

INZ: Isoniazid

iNOS: $\quad$ Nitric oxide synthase

JNK: c-Jun $\mathrm{NH}_{2}$-terminal kinase

Kep1: Kelch-like ECH-associated protein-1

LD: Lindane

LDH: Lactate dehydrogenase

$\mathrm{LD}_{50}$ : $\quad$ Lethal dose $50 \%$

LPO: $\quad$ Lipid peroxidation

MAPK: Mitogen-activated protein kinase

MAPKAPK- MAPK protein kinase-2

2:

MDA: $\quad$ Malondialdehyde

MeOH: Methanol

MoA: $\quad$ Mechanisms of action

MyD88: $\quad$ Myeloid differentiation factor 88

NF-kB: $\quad$ Nuclear factor-kappa B

NOS: $\quad$ Reactive nitrogen species

NPSM: $\quad$ Natural product small molecules

NQO-1: $\quad$ NAD(P)H:quinone oxidoreductase-1

Nrf2: $\quad$ Nuclear factor erythroid-2-related factor-2

PB: Phenobarbital

PGC-1 $\alpha$ : Peroxisome proliferator-activated receptorgamma coactivator-1alpha

PPAR $\alpha$ Peroxisome proliferator-activated receptor alpha

Prx-6: $\quad$ Peroxiredoxin-6 


$\begin{array}{ll}\text { PT: } & \text { Prothrombin time } \\ \text { PZA: } & \text { Pyrazinamide } \\ \text { RdRp: } & \text { RNA-dependent RNA polymerase } \\ \text { RIF: } & \text { Rifampicin } \\ \text { ROS: } & \text { Reactive oxygen species } \\ \text { SGOT: } & \text { Serum glutamic oxaloacetic transaminase } \\ \text { SGPT: } & \text { Serum glutamic pyruvic transaminase } \\ \alpha \text {-SMA: } & \text { Alpha-smooth muscle actin } \\ \text { sm- } \alpha: & \text { Smooth muscle } \alpha \text {-actin } \\ \text { Smad4: } & \text { Decapentaplegic homolog } 4 \\ \text { SOD: } & \text { Superoxide dismutase } \\ \text { SREBP-1c: } & \text { Sterol regulatory element-binding protein-1c } \\ \text { TAA: } & \text { Thiacetamide } \\ \text { TB: } & \text { Total bilirubin } \\ \text { TC: } & \text { Total cholesterol } \\ \text { TCA: } & \text { trans-Tetracos-15-enoic acid } \\ \text { TG: } & \text { Tryglyceride } \\ \text { TGF- } \beta: & \text { Transforming growth factor- } \beta 1 \\ \text { TLR2: } & \text { Toll-like receptor } 2 \\ \text { TLR4: } & \text { Toll-like receptor } 4 \\ \text { TNF- } \alpha: & \text { Tumor necrosis factor- } \alpha \\ \text { TP: } & \text { Total protein } \\ \text { UGT: } & \text { UDP-glucuronosyl transferase. } \\ & \end{array}$

\section{Data Availability}

All relevant data are available within this manuscript.

\section{Conflicts of Interest}

The authors declare no conflicts of interest regarding the publication of this paper.

\section{Authors' Contributions}

RR, PG, MRU, and FTZ accumulated the literature and systematically analyzed the data. RR and SJU drafted and revised the manuscript. DKS drew the figures. SJU and IM supervised the project and provided helpful comments and revisions. All authors read and approved the final version of the manuscript.

\section{References}

[1] J. Chiang, "Liver physiology: MetaboLism and detoxification," 2014.

[2] H. Jaeschke, "Toxic responses of the liver. Casarret \& Doull's Toxicology," The Science of Poisons, vol. 13, pp. 557-582, 2008.

[3] F. Cainelli, "Liver diseases in developing countries," World Journal of Hepatology, vol. 4, no. 3, pp. 66-67, 2012.

[4] J. Xiao, F. Wang, N.-K. Wong et al., "Global liver disease burdens and research trends: analysis from a Chinese perspective," Journal of Hepatology, vol. 71, no. 1, pp. 212-221, 2019.

[5] S. K. Asrani, H. Devarbhavi, J. Eaton, and P. S. Kamath, "Burden of liver diseases in the world," Journal of Hepatology, vol. 70, no. 1, pp. 151-171, 2019.

[6] S. Rahman, M. Faroque Ahmed, M. Jamshed Alam, M. Izazul Hoque, and C. Ranjan Debnath, "Distribution of liver disease in Bangladesh: a cross-country study," Euroasian
Journal of Hepato-Gastroenterology, vol. 4, no. 1, pp. 25-30, 2014.

[7] J. Khoshnur, "Herbal formulations for jaundice treatment in Jamalpur district, Bangladesh," Journal of Medicinal Plants Studies, vol. 7, no. 2, pp. 99-102, 2019.

[8] Z. Ma, B Zhang, Y Fan et al., "Traditional Chinese medicine combined with hepatic targeted drug delivery systems: a new strategy for the treatment of liver diseases," Biomedicine \& Pharmacotherapy = Biomedecine \& Pharmacotherapie, vol. 117, Article ID 109128, 2019.

[9] M. Ekor, "The growing use of herbal medicines: issues relating to adverse reactions and challenges in monitoring safety," Frontiers in Pharmacology, vol. 4, p. 177, 2014.

[10] S. A. Ali, N. H. Sharief, and Y. S. Mohamed, "Hepatoprotective activity of some medicinal plants in Sudan," Evidence-based Complementary and Alternative Medicine: eCAM, vol. 2019, Article ID 2196315, 2019.

[11] A. K. Al-Asmari, "A review of hepatoprotective plants used in saudi traditional medicine," Evidence-based Complementary and Alternative Medicine: ECAM, vol. 2014, Article ID 890842, 2014.

[12] L. Torres-González, "Review of plants with hepatoprotective activity evaluated in Mexico," Medicina Universitaria, vol. 16, no. 63, pp. 78-86, 2014.

[13] K. Okaiyeto, U. Nwodo, L. Mabinya, and A. Okoh, "A review on some medicinal plants with hepatoprotective effects," Pharmacognosy Reviews, vol. 12, no. 24, p. 186, 2018.

[14] R. V. Anupama, "Hepatoprotective ayurvedic plants - a review," Journal of Complementary and Integrative Medicine, vol. 13, no. 3, pp. 207-215, 2016.

[15] R. H. Mekky, M. R Fayed, M. R El-Gindi et al., "Hepatoprotective effect and chemical assessment of a selected egyptian chickpea cultivar," Frontiers in Pharmacology, vol. 7 , no. 344 , p. $344,2016$.

[16] M. Asadi-Samani, N. Kafash-Farkhad, N. Azimi, A. Fasihi, E. Alinia-Ahandani, and M. Rafieian-Kopaei, "Medicinal plants with hepatoprotective activity in Iranian folk medicine," Asian Pacific Journal of Tropical Biomedicine, vol. 5, no. 2, pp. 146-157, 2015.

[17] S. Thyagarajan, S. Jayaram, V. Gopalakrishnan, R. Hari, P. Jeyakumar, and M. Sripathi, "Herbal medicines for liver diseases in India," Journal of Gastroenterology and Hepatology, vol. 17, no. s3, pp. S370-S376, 2002.

[18] H. Farghali, N. K. Canová, and S. Zakhari, "Hepatoprotective properties of extensively studied medicinal plant active constituents: possible common mechanisms," Pharmaceutical Biology, vol. 53, no. 6, pp. 781-791, 2015.

[19] X. Meng, Y. Li, S. Li, R.-Y. Gan, and H.-B. Li, "Natural products for prevention and treatment of chemical-induced liver injuries," Comprehensive Reviews in Food Science and Food Safety, vol. 17, no. 2, pp. 472-495, 2018.

[20] U. Ilyas, D. P Katare, V Aeri, and P. P Naseef, "A review on hepatoprotective and immunomodulatory herbal plants," Pharmacognosy Reviews, vol. 10, no. 19, pp. 66-70, 2016.

[21] S. Handa, A. Sharma, and K. K. Chakraborti, "Natural products and plants as liver protecting drugs," Fitoterapia, vol. 57 , no. 5, pp. 307-351, 1986.

[22] C. Levy, L. Seeff, and K. Lindor, "Use of herbal supplements for chronic liver disease," Clinical Gastroenterology and Hepatology, vol. 2, no. 11, pp. 947-956, 2004. 
[23] J. L. Ríos and M. C. Recio, "Medicinal plants and antimicrobial activity," Journal of Ethnopharmacology, vol. 100, no. 1-2, pp. 80-84, 2005.

[24] S. Bardhan, S. Ashrafi, and T. Saha, "Commonly used medicinal plants in Bangladesh to treat different infection," Journal of Immunology and Pharmacology, vol. 2, no. 13, pp. 1-4, 2018.

[25] M. S. H. Chowdhury, M. Koike, N. Muhammed, M. A. Halim, N. Saha, and H. Kobayashi, "Use of plants in healthcare: a traditional ethno-medicinal practice in rural areas of southeastern Bangladesh," International Journal of Biodiversity Science \& Management, vol. 5, no. 1, pp. 41-51, 2009.

[26] A. Ghani, Medicinal Plants of Bangladesh, The Asistic Society of Bangladesh, Dhaka, Bangladesh, 2nd edition, 2003.

[27] N. F. o.B. A. Medicine, National Formulary of Bangladesh Ayurvedic Medicine, Bangladesh Board of Unani and Ayurvedic System of Medicine, Dhaka, Bangladesh, 2018.

[28] M. Yusuf, Medicinal Plants of Bangladesh, BCSIR, Dhaka, Bangladesh, 1994.

[29] S. T. Mahwasane, L. Middleton, and N. Boaduo, "An ethnobotanical survey of indigenous knowledge on medicinal plants used by the traditional healers of the Lwamondo area, Limpopo province, South Africa," South African Journal of Botany, vol. 88, pp. 69-75, 2013.

[30] A. M. Ayatollahi, M. Ghanadian, S. Afsharypuor, M. I. Choudhary, F. Kobarfard, and M. Rahmati, "Two new lathyrane type diterpenoids from Euphorbia aellenii," Fitoterapia, vol. 81, no. 7, pp. 891-893, 2010.

[31] S. Bijekar and M. Gayatri, "Ethanomedicinal properties of euphorbiaceae family-a comprehensive review," International Journal of Phytomedicine, vol. 6, pp. 144-156, 2014.

[32] K. R. Kirtikar and B. D. Basu, Indian Medicinal Plants, International Book Distributors, Dehradun, India, 1983.

[33] S. U. Nipanikar, S. S. Chitlange, and D. Nagore, "Pharmacological evaluation of hepatoprotective activity of AHPL/ AYTAB/0613 tablet in carbon tetrachloride-, ethanol-, and paracetamol-induced hepatotoxicity models in wistar albino rats," Pharmacognosy Research, vol. 9, no. 1, pp. S41-s47, 2017.

[34] S. Kumar and S. Mishra, "Hepatoprotective effect of Baliospermum montanum (Willd) Muell.-Arg against thioacetamide induced toxicity," International Journal of Comprehensive Pharmacy, vol. 9, pp. 1-4, 2012.

[35] R. R. Wadekar, "Screening of roots of Baliospermum montanum for hepatoprotective activity against paracetamol induced liver damage in albino rats," International Journal of Green Pharmacy (IJGP), vol. 2, no. 4, 2008.

[36] S. S. Kumar and S. Mishra, "Hepatoprotective activity of Baliospermum montanum (willd) Muell.-Arg. in rats treated with carbon tetrachloride: in vivo and in vitro studies," Pharmacognosy Magazine, vol. 5, no. 19, p. 196, 2009.

[37] S. Suresh Kumar and S. Mishra, "Protective effect of extracts of Baliospermum montanum (Willd.) Muell.-Arg. against paracetamol-induced hepatotoxicity-an in vivoand in vitrostudy," Ancient Science of Life, vol. 33, no. 4, p. 216, 2014.

[38] M. J. M. Christenhusz and J. W. Byng, "The number of known plants species in the world and its annual increase," Phytotaxa, vol. 261, no. 3, pp. 201-217, 2016.

[39] N. D. Parajapati, P. S. Sharma, and T. Kumar, A Handbook of Medical Plants: A Complete Source Book, Agrobios, Jodhpur, India, 2007.
[40] S. Vakiloddin, N Fuloria, S Fuloria, S. A Dhanaraj, K Balaji, and S Karupiah, "Evidences of hepatoprotective and antioxidant effect of Citrullus colocynthis fruits in paracetamol induced hepatotoxicity," Pakistan Journal of Pharmaceutical Sciences, vol. 28, no. 3, pp. 951-957, 2015.

[41] A. I. Dar, R. C. Saxena, and S. K. Bansal, "Hepatoprotection: a hallmark of Citrullus colocynthis L. against paracetamol induced hepatotoxicity in Swiss albino rats," American Journal of Plant Sciences, vol. 3, no. 7, pp. 1022-1027, 2012.

[42] O. O. Adeyemi, I. O. Ishola, and I. D. Ajani, "Citrullus colocynthis Linn. Fruit extract ameliorates cisplatin-induced hepato-renal toxicity in rats," Journal of Complementary \& Integrative Medicine, vol. 15, no. 1, 2017.

[43] W.-j. Yang, "Protection of Citrullus colocynthis fruit extracts on carbon tetrachloride-induced and Bacillus calmetteguerin plus lipopolysaccharide-induced hepatotoxicity in mice," Chinese Herbal Medicines, vol. 5, no. 3, pp. 205-211, 2013.

[44] A. I. Dar, "Protective effect of Citrullus colocynthis L. against polluted water induced hepatotoxicity in albino rats," International Journal of Biological \& Pharmaceutical Research, vol. 3, no. 2, pp. 240-244, 2012.

[45] A. Mukerjee, P. Visen, and S. Saraf, "Evaluation of hepatoprotectivte activity of Citrullus colocynthis roots against CCl4 induced toxicity in albino rats," Natural Product Sciences, vol. 13, no. 1, pp. 23-26, 2007.

[46] O. R. Oyenihi, B. A. Afolabi, A. B. Oyenihi, O. J. Ogunmokun, and O. O. Oguntibeju, "Hepato- and neuro-protective effects of watermelon juice on acute ethanol-induced oxidative stress in rats," Toxicology Reports, vol. 3, pp. 288-294, 2016.

[47] Y.-Y. Zhan, J.-H. Wang, X. Tian, S.-X. Feng, L. Xue, and L.-P. Tian, "Protective effects of seed melon extract on CCl4induced hepatic fibrosis in mice," Journal of Ethnopharmacology, vol. 193, pp. 531-537, 2016.

[48] D. A. Omoboyowa, "Protective effect of methanol seed extract of Citrullus lanatus on paracetamol-induced hepatotoxicity in adult wistar rats," Global Journal of Pharmacology, vol. 10, no. 2, pp. 60-67, 2016.

[49] O. Omotoso, "Hepatoprotective activity of aqueous and methanolic extracts of watermelon seeds on salt and paracetamol-induced liver damage in female white rates," International Research Journal of Natural Sciences, vol. 6, no. 1, pp. 1-12, 2018.

[50] A. Adebayo, T. Balogun, and O. Yakubu, "Hepatoprotective properties of the leaf extract of Citrullus lanatus (Thunb.) on carbon tetrachloride induced liver damage in rats," Planta Medica, vol. 80, no. 16, p. P2O30, 2014.

[51] N. Nithya, "Efficacy of Momordica charantia in attenuating hepatic abnormalities in cyclophosphamide intoxicated rats," Journal of Pharmacology and Toxicology, vol. 7, pp. 38-45, 2012.

[52] V. Janghel, P. Patel, and S. S. Chandel, "Plants used for the treatment of icterus (jaundice) in Central India: a review," Annals of Hepatology, vol. 18, no. 5, pp. 658-672, 2019.

[53] S. Mada, "Hepatoprotective effect of Momordica charantia extract against CCl4 induced liver damage in rats," British Journal of Pharmaceutical Research, vol. 4, no. 3, pp. 368380, 2014.

[54] V. Chaware, Y. Joshi, and K. Biyani, "Hepatoprotective activity of hydroalcoholic extract of Momordica charantia Linn. leaves against carbon tetra chloride induced hepatopathy in rats," International Journal of ChemTech Research, vol. 1, no. 2, pp. 355-358, 2009. 
[55] G. Moharir, A. Bharatha, N. Ojeh, and V. Prasad S, "Evaluation of Hepatoprotective effect of hydroalcoholic extract of Momordica Charantia leaves in carbon tetrachloride induced liver toxicity in Wistar rats," Biomedical \& Pharmacology Journal, vol. 12, no. 3, pp. 1555-1560, 2019.

[56] Y. Deng, Q Tang, Y Zhang et al., "Protective effect of Momordica charantia water extract against liver injury in restraint-stressed mice and the underlying mechanism," Food \& Nutrition Research, vol. 61, no. 1, Article ID 1348864, 2017.

[57] A. Thenmozhi and P. Subramanian, "Hepatoprotective effect of Momordica charantia in ammonium chloride induced hyperammonemic rats," Journal of Pharmacy Research, vol. 4, no. 3, pp. 700-702, 2011.

[58] C. Jeffrey, "Compositae: introduction with key to tribes," in Flowering Plants, Eudicots, J. W. Kadereit, and C. Jeffrey, Eds., pp. 61-87, Springer-Verlag Berlin Heidelberg, Berlin, Germany, 2007.

[59] J. A. Duke, P. K. Duke, and J. L. duCellie, Duke's Handbook of Medicinal Plants of the Bible, CRC Press, Boca Raton, FL, USA, 2008.

[60] H. S. Yar, D. K. Ismail, and M. N. Alhmed, "Hepatoprotective effect of Carthamus tinctorius L. against carbon tetrachloride induced hepatotoxicity in rats," Pharmacie Globale, vol. 3, no. 9, p. 1, 2012.

[61] S. Asgary, "Hepatoprotective and hypolipidemic effects of Carthamus tinctorius oil in alloxan-induced type 1 diabetic rats," Journal of HerbMed Pharmacology, vol. 3, 2014.

[62] C. Ramesh, Y. Ravi Kumar, M. Paramesha, V. Krishna, and K. M. Parvathi, "Hepatoprotective and in vitro antioxidant effect of Carthamus tinctorious L, var Annigeri-2-, an oilyielding crop, against CCl4-induced liver injury in rats," Pharmacognosy Magazine, vol. 7, no. 28, pp. 289-297, 2011.

[63] K. R. Kirtikar, B. D. Basu, and L. M. Basu, Indian Medicinal Plants, Council of Scientific and Industrial Research, Allahabad, India, 2nd edition, 1956.

[64] B. Singh, A. K. Saxena, B. K. Chandan, S. G. Agarwal, M. S. Bhatia, and K. K. Anand, "Hepatoprotective effect of ethanolic extract ofEclipta alba on experimental liver damage in rats and mice," Phytotherapy Research, vol. 7, no. 2, pp. 154-158, 1993.

[65] T. Thirumalai, E. David, S. V. Therasa, and E. Elumalai, "Restorative effect of Eclipta alba in CCl4 induced hepatotoxicity in male albino rats," Asian Pacific Journal of Tropical Disease, vol. 1, no. 4, pp. 304-307, 2011.

[66] V. Lal, "Screening of leaves and roots of Eclipta alba for hepatoprotective activity," Archives of Applied Science Research, vol. 2, no. 1, pp. 86-94, 2010.

[67] P. Baranisrin, E. K. Elumalai, C. Sivakumar, S. V. Therasa, and E. David, "Hepatoprotective effect of Enicostemma littorale blume and Eclipta alba during ethanol induced oxidative stress in albino rats," International Journal of Pharmacology, vol. 5, no. 4, pp. 268-272, 2009.

[68] W. Y. Ho, S. K Yeap, C. L Ho, R Abdul Rahim, and N. B Alitheen, "Hepatoprotective activity of Elephantopus scaber on alcohol-induced liver damage in mice," Evidencebased Complementary and Alternative Medicine: ECAM, vol. 2012, Article ID 417953, 2012.

[69] Y. Y. Li, "321 cases clinical observation of chronic hepatitis B and liver cirrhosis treated with "Yi Gan Yin"” The Medicine Magazine of China, vol. 3, pp. 92-93, 2006.

[70] K. O. Sheeba, P. J. Wills, B. K. Latha, R. Rajalekshmy, and M. S. Latha, "Antioxidant and antihepatotoxic efficacy of methanolic extract of Elephantopus scaber Linn in Wistar rats," Asian Pacific Journal of Tropical Disease, vol. 2, pp. S904-S908, 2012.

[71] M. G. Rajesh and M. S. Latha, "Hepatoprotection by Elephantopus scaber Linn. in CCl4-induced liver injury," Indian Journal of Physiology and Pharmacology, vol. 45, no. 4, pp. 481-486, 2001.

[72] A. Okhuarobo, J. Ehizogie Falodun, O. Erharuyi, V. Imieje, A. Falodun, and P. Langer, "Harnessing the medicinal properties of Andrographis paniculata for diseases and beyond: a review of its phytochemistry and pharmacology," Asian Pacific Journal of Tropical Disease, vol. 4, no. 3, pp. 213-222, 2014.

[73] S. K. Mishra, N. S. Sangwan, and R. S. Sangwan, "Andrographis paniculata (kalmegh): a review," Pharmacognosy Reviews, vol. 1, no. 2, pp. 283-298, 2007.

[74] L. S. Chua, "Review on liver inflammation and antiinflammatory activity of andrographis paniculata for hepatoprotection," Phytotherapy Research, vol. 28, no. 11, pp. 1589-1598, 2014.

[75] V. J. Ram, "Herbal preparations as a source of hepatoprotective agents," Drug News \& Perspectives, vol. 14, no. 6, pp. 353-363, 2001.

[76] N. P. Trivedi and U. M. Rawal, "Hepatoprotective and antioxidant property of Andrographis paniculata (Nees) in BHC induced liver damage in mice," Indian Journal of Experimental Biology, vol. 39, no. 1, pp. 41-46, 2001.

[77] D. A. Bardi, "Andrographis paniculata leaf extract prevents thioacetamide-induced liver cirrhosis in rats," PLoS One, vol. 9, no. 10, Article ID e109424, 2014.

[78] A. C. Rana and Y. Avadhoot, "Hepatoprotective effects ofAndrographis paniculata against carbon tetrachlorideinduced liver damage," Archives of Pharmacal Research, vol. 14, no. 1, pp. 93-95, 1991.

[79] N. Trivedi and U. Rawal, "Hepatoprotective and toxicological evaluation of Andrographis paniculata on severe liver damage," Indian Journal of Pharmacology, vol. 32, no. 5, pp. 288-293, 2000.

[80] R. Nagalekshmi, A. Menon, D. K. Chandrasekharan, and C. K. K. Nair, "Hepatoprotective activity of Andrographis paniculata and Swertia chirayita," Food and Chemical Toxicology, vol. 49, no. 12, pp. 3367-3373, 2011.

[81] V. Subramaniyan, S. Uthirapathy, and G. V. Rajamanickam, "Hepatoprotective activity of Andrographis paniculata in ethanol induced hepatotoxicity in albino Wistar rats," Pharmacie Globale, vol. 2, no. 2, pp. 1-4, 2011.

[82] M. Yoshikawa, K. Ninomiya, H. Shimoda, N. Nishida, and H. Matsuda, "Hepatoprotective and antioxidative properties of Salacia reticulata: preventive effects of phenolic constituents on $\mathrm{CCl}_{4}$-induced liver injury in mice," Biological and Pharmaceutical Bulletin, vol. 25, no. 1, pp. 72-76, 2002.

[83] E. Prakash, "Evaluation of In-vitro antioxidant activity of leaf extract of Andrographis paniculata," Research Journal of Pharmaceutical, Biological and Chemical Sciences, vol. 2, no. 2, pp. 891-895, 2011.

[84] S. Das, N. Gautam, S. K. Dey, T. Maiti, and S. Roy, "Oxidative stress in the brain of nicotine-induced toxicity: protective role of Andrographis paniculata Nees and vitamin E," Applied Physiology, Nutrition, and Metabolism, vol. 34, no. 2, pp. 124-135, 2009.

[85] F. L. Lin, S. J. Wu, S. C. Lee, and L. T. Ng, "Antioxidant, antioedema and analgesic activities ofAndrographis paniculataextracts and their active constituent andrographolide," Phytotherapy Research, vol. 23, no. 7, pp. 958-964, 2009. 
[86] K. R. Kirtikar and B. D. Basu, Kirtikar \& Basu's Illustrated Indian Medicinal Plants, Satguru Publications, New Delhi, India, 2000.

[87] K. Karthikeyan, B. R. Sarala Bai, K. Gauthaman, K. S. Sathish, and S. N. Devaraj, "Cardioprotective effect of the alcoholic extract of Terminalia arjuna bark in an in vivo model of myocardial ischemic reperfusion injury," Life Sciences, vol. 73, no. 21, pp. 2727-2739, 2003.

[88] P. Doorika and T. Ananthi, "Antioxidant and hepatoprotective properties of Terminalia arjuna bark on isoniazid induced toxicity in albino rats," Asian Journal of Pharmacy and Technology, vol. 2, no. 1, pp. 15-18, 2012.

[89] S. A. Tasduq, K. Singh, N. K. Satti, D. K. Gupta, K. A. Suri, and R. K. Johri, "Terminalia chebula (fruit) prevents liver toxicity caused by sub-chronic administration of rifampicin, isoniazid and pyrazinamide in combination," Human \& Experimental Toxicology, vol. 25, no. 3, pp. 111-118, 2006.

[90] A. Vishwakarma, "Screening of hepatoprotective potential of ethanolic and aqueous extract of Terminalia arjuna bark against paracetamol/CCl4 induced liver damage in Wister albino rats," International Journal of Pharmaceutical Archive, vol. 2, no. 10, pp. 243-250, 2013.

[91] C. Girish, "Hepatoprotective activity of six polyherbal formulation in CCl4 induced liver toxicity in mice," Indian Journal of Experimental Biology, vol. 47, pp. 257-263, 2009.

[92] T. Yeasmin, Q. S. Akhter, S. T. Siddika, and F. Karim, "Effect of Terminalia chebula (haritaki) on serum aspartate aminotransferase, alanine aminotransferase in paracetemol induced liver damage in wister albino rats," Journal of Bangladesh Society of Physiologist, vol. 10, no. 1, pp. 1-5, 2015.

[93] K. K. Anand, B. Singh, A. K. Saxena, B. K. Chandan, and V. N. Gupta, "Hepatoprotective studies of a fraction from the fruits ofTerminalia belerica roxb. On experimental liver injury in rodents," Phytotherapy Research, vol. 8, no. 5, pp. 287-292, 1994.

[94] J. C. Gogoi, D. Mohanta, and P. K. Borah, "Hepatoprotective activity of averrhoa carambola, Cajanus cajan and paederia foetida against acetaminophen and D-galactosamine induced hepatotoxicity in rats," Journal of Pharmaceutical Research, vol. 9, no. 2, pp. 76-80, 2010.

[95] M. R. Ahsan, "Hepatoprotective activity of methanol extract of some medicinal plants against carbon tetrachloride-induced hepatotoxicity in rats," European Journal of Scientific Research, vol. 37, no. 2, pp. 302-310, 2009.

[96] O. A. Akinloye and M. O. Olaniyi, "Hepatoprotective effect of Cajanus cajan on tissue defense system in D-galactosamine-induced hepatitis in rats," Turkish Journal of Biochemistry, vol. 36, no. 3, pp. 237-241, 2011.

[97] R. Kundu, S. Dasgupta, A. Biswas et al., "Cajanus cajan Linn. (Leguminosae) prevents alcohol-induced rat liver damage and augments cytoprotective function," Journal of Ethnopharmacology, vol. 118, no. 3, pp. 440-447, 2008.

[98] T. Bhakta, S. Banerjee, S. C. Mandal, T. K. Maity, B. P. Saha, and M. Pal, "Hepatoprotective activity of Cassia fistula leaf extract," Phytomedicine, vol. 8, no. 3, pp. 220-224, 2001.

[99] T. Bhakta, P. K. Mukherjee, K. Mukherjee et al., "Evaluation of hepatoprotective activity of Cassia fistula leaf extract," Journal of Ethnopharmacology, vol. 66, no. 3, pp. 277-282, 1999.

[100] K. Chittam and V. Patil, "Hepatoprotective activity of Cassia fistula seeds against paracetamol-induced hepatic injury in rats," Archives of Pharmacal Research, vol. 2, no. 4, pp. 218-221, 2009.
[101] H. Kalantari, M. Jalali, A. Jalali et al., "Protective effect of Cassia fistula fruit extract against bromobenzene-induced liver injury in mice," Human \& Experimental Toxicology, vol. 30, no. 8, pp. 1039-1044, 2011.

[102] S. Das, G. Sarma, and S. Barman, "Hepatoprotective activity of aqueous extract of fruit pulp of Cassia fistula (AFCF) against carbon tetrachloride $\left(\mathrm{CCL}_{4}\right)$ induced liver damage in albino rats," Journal of Clinical and Diagnostic Research, vol. 2, no. 5, pp. 1133-1138, 2008.

[103] K. Pradeep, C. V. R. Mohan, K. Gobianand, and S. Karthikeyan, "Effect of Cassia fistula Linn. leaf extract on diethylnitrosamine induced hepatic injury in rats," ChemicoBiological Interactions, vol. 167, no. 1, pp. 12-18, 2007.

[104] A. Jehangir, "The hepatoprotective effect of Cassia fistula (amaltas) leaves in isoniazid and rifampicin induced hepatotoxicity in rodents," Biomedica, vol. 26, no. 1, pp. 25-29, 2010.

[105] A. E. Ubhenin, I. Igbe, F. A. Adamude, and A. Falodun, "Hepatoprotective effects of ethanol extract of Caesalpiniabonduc against carbon tetrachloride induced hepatotoxicity in Albino Rats," Journal of Applied Sciences and Environmental Management, vol. 20, no. 2, pp. 396-401, 2016.

[106] A. A. Noorani, "Protective effect of methanolic leaf extract of Caesalpinia bonduc (L.) on gentamicin-induced hepatotoxicity and nephrotoxicity in rats," Iranian Journal of Pharmacology and Therapeutics, vol. 10, no. 1, pp. 21-30, 2011.

[107] S. Sumalatha, "Hepatoprotective activity of aqueous extract of Caesalpinia bonduc against $\mathrm{CCl} 4$ induced chronic hepatotoxicity," International Journal of Pharmacy and Pharmaceutical Sciences, vol. 8, no. 4, pp. 207-211, 2016.

[108] M. Gupta, U. K. Mazumder, and R. S. Kumar, "Hepatoprotective effects and antioxidant role of Caesalpinia bonducella on paracetamol-induced hepatic damage in rats," Natural Product Sciences, vol. 9, no. 3, pp. 186-191, 2003.

[109] R. S. Kumar, K. A. Kumar, and N. V. Murthy, "Hepatoprotective and antioxidant effects of Caesalpinia bonducella on carbon tetrachloride-induced liver injury in rats," International Research Journal of Plant Science, vol. 1, no. 3, pp. 062-068, 2010.

[110] N. Veena, "Hepatoprotective activity of Aloe vera gel against paracetamol induced hepatotoxicity in albino rats," Asian Journal of Pharmaceutical and Biological Research, vol. 1, no. 2, pp. 94-98, 2011.

[111] W. A. Saka, R. E. Akhigbe, O. S. Ishola, E. A. Ashamu, O. T. Olayemi, and G. E. Adeleke, "Hepatotherapeutic effect of aloe vera in alcohol-induced hepatic damage," Pakistan Journal of Biological Sciences, vol. 14, no. 14, pp. 742-746, 2011.

[112] O. E. Etim, E. O Farombi, I. F Usoh, and E. J Akpan, “The protective effect of aloe vera juice on lindane induced hepatotoxicity and genotoxicity," Pakistan Journal of Pharmaceutical Sciences, vol. 19, no. 4, pp. 337-340, 2006.

[113] G. Zodape and P. Bhise, "Effect of aloe vera extract on the hepatotoxicity induced by isoniazid and rifampicin drug in male wistar rats," International Journal of Pharmaceutical Sciences and Research, vol. 7, no. 3, p. 1314, 2016.

[114] R. A. Salma, "Assessment effect of Aloe vera, azadirachta indica and Moringa oleifera aqueous extracts on carbon tetrachloride-induced hepatotoxicity in rats," International Journal of Pharmacy and Pharmaceutical Sciences, vol. 8, no. 4, pp. 83-89, 2016. 
[115] S.-H. Kim, H. J. Cheon, N. Yun et al., "Protective effect of a mixture of aloe vera and silybum marianum against carbon tetrachloride-induced acute hepatotoxicity and liver fibrosis," Journal of Pharmacological Sciences, vol. 109, no. 1, pp. 119-127, 2009.

[116] S. Bhatt, "Evaluation of hepatoprotective activity of Aloe Vera in acute viral hepatitis," International Journal of Pharmaceutical Sciences and Research, vol. 5, no. 6, p. 2479, 2014.

[117] M. L. A. D. Lestari and G. Indrayanto, "Curcumin," Profiles of Drug Substances, Excipients and Related Methodology, vol. 39, pp. 113-204, 2014.

[118] S. J. Uddin, "Curcumin and its multi-target function against pain and inflammation: an update of pre-clinical data," Current Drug Targets, vol. 22, no. 6, 2020.

[119] S. M. Salama, M. A. Abdulla, A. S. AlRashdi, S. Ismail, S. S. Alkiyumi, and S. Golbabapour, "Hepatoprotective effect of ethanolic extract of Curcuma longa on thioacetamide induced liver cirrhosis in rats," BMC Complementary and Alternative Medicine, vol. 13, no. 1, p. 56, 2013.

[120] M. R. Adhvaryu, N. Reddy, and M. H. Parabia, "Effects of four Indian medicinal herbs on Isoniazid-, Rifampicin- and Pyrazinamide-induced hepatic injury and immunosuppression in Guinea pigs," World Journal of Gastroenterology, vol. 13, no. 23, p. 3199, 2007.

[121] O. Adaramoye, A. Odunewu, and E. Farombi, "Hepatoprotective effect of Curcuma longa L. in D-galactosamine induced liver injury in mice: evidence of antioxidant activity," African Journal of Medicine and Medical Sciences, vol. 39, pp. 27-34, 2010.

[122] G.-H. Lee, H.-Y. Lee, M.-K. Choi, H.-W. Chung, S.-W. Kim, and H.-J. Chae, "Protective effect of Curcuma longa L. extract on CCl4-induced acute hepatic stress," BMC Research Notes, vol. 10, no. 1, p. 77, 2017.

[123] D. Joshi, D. K. Mittal, S. Shukla, S. K. Srivastav, and V. A. Dixit, "Curcuma longa Linn. extract and curcumin protect CYP 2E1 enzymatic activity against mercuric chloride-induced hepatotoxicity and oxidative stress: a protective approach," Experimental and Toxicologic Pathology, vol. 69, no. 6, pp. 373-382, 2017.

[124] M. Ahmad, S. H. Kamran, and A. Mobasher, "Protective effect of crude Curcuma longa and its methanolic extract in alloxanized rabbits," Pakistan Journal of Pharmaceutical Sciences, vol. 27, no. 1, pp. 121-8, 2014.

[125] H. Zeashan, G. Amresh, S. Singh, and C. V. Rao, "Hepatoprotective activity of Amaranthus spinosus in experimental animals," Food and Chemical Toxicology, vol. 46, no. 11, pp. 3417-3421, 2008.

[126] A. Kumar, "Chemoprotective and antioxidant activities of methanolic extract of amaranthus spinosus leaves on paracetamol induced liver damage in rats," Acta Medica Saliniana, vol. 39, 2010.

[127] H. Zeashan, G. Amresh, S. Singh, and C. V. Rao, "Protective effect ofAmaranthus spinosusagainstd-galactosamine/lipopolysaccharide-induced hepatic failure," Pharmaceutical Biology, vol. 48, no. 10, pp. 1157-1163, 2010.

[128] T. Sourabie, "Evaluation of the antihepatotoxic effect of Argemone mexicana leaf extracts against $\mathrm{CCl}_{4}$-induced hepatic injury in rats," International Journal of Biological and Chemical Sciences, vol. 3, no. 6, 2009.

[129] T. Sourabie, "Evaluation of the anti-icterus effect of crude powdered leaf of Argemone mexicana L.(Papaveraceae) against $\mathrm{CCl}_{4}$-induced liver injury in rats," International
Journal of Pharmaceutical Sciences and Research, vol. 3, pp. 491-496, 2012.

[130] S. Adam, "Evaluation of hepatoprotective activity of argemone mexicana aerial part extracts on $\mathrm{CCL}_{4}$ induced liver damage in wistar rats," British Journal of Pharmacology and Toxicology, vol. 2, no. 5, pp. 251-256, 2011.

[131] B. Radhika, N. Begum, and K. Srisailam, "Hepatoprotective activity of bixa orellana linn leaf extracts," International Journal of Pharmacy and Pharmacology, vol. 109, no. 1, 2017.

[132] W. Obidah, "Protective effects of Bixa orellana seed oil on carbon tetrachloride induced liver damage in rats," Report and Opinion, vol. 3, no. 1, pp. 92-95, 2011.

[133] M. Singh, "Hepatoprotective evaluaiton of Bixa orellana L. seed extract against acute ethanol induced hepatotoxicity in rats," International Journal of Pharmaceutical Sciences and Research, vol. 9, no. 12, pp. 5168-5176, 2018.

[134] A. Jayavelu, "Hepatoprotective activity of Boerhavia diffusa L.(Nyctaginaceae) against ibuprofen induced hepatotoxicity in wistar albino rats," International Journal of Pharmaceutical Sciences Review and Research, vol. 2, pp. 1-8, 2013.

[135] B. K. Chandan, A. K. Sharma, and K. K. Anand, "Boerhaavia diffusa: a study of its hepatoprotective activity," Journal of Ethnopharmacology, vol. 31, no. 3, pp. 299-307, 1991.

[136] P. Monali and V. Ramtej, "Hepatoprotective activity of Boerhavia diffusa extract," International Journal of Pharmaceutical and Clinical Research, vol. 6, no. 3, pp. 233-240, 2014.

[137] O. Awodele, O. Yemitan, P. Ise, and V. Ikumawoyi, "Modulatory potentials of aqueous leaf and unripe fruit extracts of carica papaya linn. (caricaceae) against carbon tetrachloride and acetaminophen-induced hepatotoxicity in rats," Journal of Intercultural Ethnopharmacology, vol. 5, no. 1 , p. 27, 2016.

[138] J. Minari and F. Bamisaye, "Studies on the effect of methanolic extract of Carica papaya stalk on hepatotoxicity induced in albino rat," Journal of Medicinal Plants Research, vol. 7, no. 45, pp. 3314-3318, 2013.

[139] N. Eze Kingsley, "Modulatory activity of aqueous extract of Carica papaya (L.) seed on carbon tetrachloride induced hepatotoxicity in wistar rats," Journal of Pharmaceutical Advanced Research, vol. 2, no. 5, pp. 216-222, 2012.

[140] M. Z. Sadeque and Z. A. Begum, "Protective effect of dried fruits of Carica papaya on hepatotoxicity in rat," Bangladesh Journal of Pharmacology, vol. 5, no. 1, pp. 48-50, 2010.

[141] A. Adeneye, "The aqueous seed extract of Carica papaya Linn. Prevents carbon tetrachloride induced hepatotoxicity in rats," International Journal of Applied Research in Natural Products, vol. 2, no. 2, pp. 19-32, 2009.

[142] S. Shoba, P. Patil, and V. Vivek, "Hepatoprotective activity of Daucus carota L. aqueous extract against paracetamol, isoniazid and alcohol induced hepatotoxicity in male wistar rats," Pharmacologyonline, vol. 3, pp. 776-787, 2008.

[143] P. Balasubramaniam, L. Pari, and V. P. Menon, "Protective effect of carrot (Daucus carota L.) against lindane - induced hepatotoxicity in rats," Phytotherapy Research, vol. 12, no. 6, pp. 434-436, 1998.

[144] W. N. Shebaby, C. F. Daher, M. El-Sibai et al., "Antioxidant and hepatoprotective activities of the oil fractions from wild carrot (Daucus carotassp.carota)," Pharmaceutical Biology, vol. 53, no. 9, pp. 1285-1294, 2015.

[145] R. Simeonova, M Kondeva-Burdina, V Vitcheva, and M Mitcheva, "Some in vitro/in vivo chemically-induced experimental models of liver oxidative stress in rats," BioMed Research International, vol. 2014, Article ID 706302, , 2014. 
[146] Y. K. Zhang, K. C. Wu, and C. D. Klaassen, "Genetic activation of Nrf2 protects against fasting-induced oxidative stress in livers of mice," PLoS One, vol. 8, no. 3, Article ID e59122, 2013.

[147] Y. P. Hwang, J. H. Choi, H. J. Yun et al., “Anthocyanins from purple sweet potato attenuate dimethylnitrosamine-induced liver injury in rats by inducing Nrf2-mediated antioxidant enzymes and reducing COX-2 and iNOS expression," Food and Chemical Toxicology, vol. 49, no. 1, pp. 93-99, 2011.

[148] A. Olalekan Lawal, A. Folusho Lawal, A. Ologundudu, O. Yakubu Adeniran, A. Omonkhua, and F. Obi, "Antioxidant effects of heated garlic juice on cadmium-induced liver damage in rats as compared to ascorbic acid," The Journal of Toxicological Sciences, vol. 36, no. 5, pp. 549-557, 2011.

[149] J. H. Choi, S. W. Jin, H. G. Kim et al., "Platycodi Radix attenuates dimethylnitrosamine-induced liver fibrosis in rats by inducing Nrf2-mediated antioxidant enzymes," Food and Chemical Toxicology, vol. 56, pp. 231-239, 2013.

[150] A. Zhang, H. Sun, and X. Wang, "Recent advances in natural products from plants for treatment of liver diseases," $E u$ ropean Journal of Medicinal Chemistry, vol. 63, pp. 570-577, 2013.

[151] E. Madrigal-Santillán, "Review of natural products with hepatoprotective effects," World Journal of Gastroenterology, vol. 20, no. 40, pp. 14787-14804, 2014.

[152] N. Kumar and N. Goel, "Phenolic acids: natural versatile molecules with promising therapeutic applications," Biotechnology Reports (Amsterdam, Netherlands), vol. 24, Article ID e00370, 2019.

[153] S. Casas-Grajales and P. Muriel, "Antioxidants in liver health," World Journal of Gastrointestinal Pharmacology and Therapeutics, vol. 6, no. 3, pp. 59-72, 2015.

[154] M. Tai, J. Zhang, S. Song et al., "Protective effects of luteolin against acetaminophen-induced acute liver failure in mouse," International Immunopharmacology, vol. 27, no. 1, pp. 164-170, 2015.

[155] T. Xu, S. Huang, Q. Huang et al., "Kaempferol attenuates liver fibrosis by inhibiting activin receptor-like kinase 5," Journal of Cellular and Molecular Medicine, vol. 23, no. 9, pp. 6403-6410, 2019.

[156] J. Yang, X.-Y. Wang, J. Xue, Z.-L. Gu, and M.-L. Xie, "Protective effect of apigenin on mouse acute liver injury induced by acetaminophen is associated with increment of hepatic glutathione reductase activity," Food \& Function, vol. 4, no. 6, pp. 939-943, 2013.

[157] K. Amarnath, S. Heleena, and S. Ayyappan, "Hepatoprotectivity of rutin isolated from Amaranthus spinosus against $\mathrm{CCl}_{4}$ induced hepatic damage in albino rats," Journal of Pharmacy Research, vol. 3, no. 8, pp. 1991-1996, 2010.

[158] Y. Wang, C. Tang, and H. Zhang, "Hepatoprotective effects of kaempferol 3-O-rutinoside and kaempferol 3-O-glucoside from Carthamus tinctorius L. on $\mathrm{CCl}_{4}$-induced oxidative liver injury in mice," Journal of Food and Drug Analysis, vol. 23, no. 2, pp. 310-317, 2015.

[159] D. Pitchai and R. Manikkam, "Hypolipidemic, hepatoprotective and renal damage recovering effects of catechin isolated from the methanolic extract of Cassia fistula stem bark on Streptozotocin-induced diabetic Wistar rats: a biochemical and morphological analysis," Medicinal Chemistry Research, vol. 21, no. 12, pp. 4535-4541, 2012.

[160] R. Domitrović, H Jakovac, V Vasiljev Marchesi et al., "Differential hepatoprotective mechanisms of rutin and quercetin in $\mathrm{CCl}(4)$-intoxicated $\mathrm{BALB} / \mathrm{cN}$ mice," Acta Pharmacologica Sinica, vol. 33, no. 10, pp. 1260-1270, 2012.
[161] S. Li, H. Y Tan, N Wang, F Cheung, M Hong, and Y Feng, "The potential and action mechanism of polyphenols in the treatment of liver diseases," Oxidative Medicine and Cellular Longevity, vol. 2018, Article ID 8394818, 2018.

[162] A. Jain, A. Singhai, and V. Dixit, "A comparative study of ethanol extract of leaves of Tephrosia purpureapers and the flavonoid isolated for hepatoprotective activity," Indian Journal of Pharmaceutical Sciences, vol. 68, no. 6, p. 740, 2006.

[163] J. Y. Lee, E. J. Chang, H. J. Kim, J. H. Park, and S. W. Choi, "Antioxidative flavonoids from leaves ofCarthamus tinctorius," Archives of Pharmacal Research, vol. 25, no. 3, pp. 313-319, 2002.

[164] S. Thabit, H. Handoussa, M. Roxo, N. S. El Sayed, B. Cestari de Azevedo, and M. Wink, "Evaluation of antioxidant and neuroprotective activities of Cassia fistula (L.) using the Caenorhabditis elegans model," PeerJ, vol. 6, p. e5159, 2018.

[165] M. Kassem, "Bioactive flavonoids from Tephrosia purpurea," Natural Product Communication, vol. 1, pp. 953-955, 2006.

[166] K. H. Miean and S. Mohamed, "Flavonoid (myricetin, quercetin, kaempferol, luteolin, and apigenin) content of edible tropical plants," Journal of Agricultural and Food Chemistry, vol. 49, no. 6, pp. 3106-3112, 2001.

[167] M. Sobeh, A. Esmat, G. Petruk et al., "Phenolic compounds from Syzygium jambos (Myrtaceae) exhibit distinct antioxidant and hepatoprotective activities in vivo," Journal of Functional Foods, vol. 41, pp. 223-231, 2018.

[168] T. Sakurai, M. Kudo, A. Umemura et al., "p38 $\alpha$ inhibits liver fibrogenesis and consequent hepatocarcinogenesis by curtailing accumulation of reactive oxygen species," Cancer Research, vol. 73, no. 1, pp. 215-224, 2013.

[169] I. Cordero-Herrera, M. A. Martín, L. Goya, and S. Ramos, "Cocoa flavonoids protect hepatic cells against high-glucoseinduced oxidative stress: relevance of MAPKs," Molecular Nutrition \& Food Research, vol. 59, no. 4, pp. 597-609, 2015.

[170] A. B. Hsouna, S. Mongi, G. Culioli et al., "Protective effects of ethyl acetate fraction of Lawsonia inermis fruits extract against carbon tetrachloride-induced oxidative damage in rat liver," Toxicology and Industrial Health, vol. 32, no. 4, pp. 694-706, 2013.

[171] U. Latief, H. Husain, D. Mukherjee, and R. Ahmad, "Hepatoprotective efficacy of gallic acid during Nitrosodiethylamine-induced liver inflammation in Wistar rats," The Journal of Basic \& Applied Zoology, vol. 76, pp. 31-41, 2016.

[172] H.-S. Lee, S.-H. Jung, B.-S. Yun, and K.-W. Lee, "Isolation of chebulic acid from Terminalia chebula Retz. and its antioxidant effect in isolated rat hepatocytes," Archives of Toxicology, vol. 81, no. 3, pp. 211-218, 2007.

[173] H.-L. Jung, S.-Y. Yang, M. C. Pyo et al., "Protective effects of chebulic acid from Terminalia chebula Retz. against t-BHPinduced oxidative stress by modulations of $\mathrm{Nrf} 2$ and its related enzymes in HepG2 cells," Food Science and Biotechnology, vol. 28, no. 2, pp. 555-562, 2018.

[174] C. Girish and S. C. Pradhan, "Herbal drugs on the liver," in Liver Pathophysiology, P. Muriel, Ed., Academic Press, Boston, MA, USA, pp. 605-620, 2017.

[175] P. K. Singha, S. Roy, and S. Dey, "Protective activity of andrographolide and arabinogalactan proteins from Andrographis paniculata Nees. against ethanol-induced toxicity in mice," Journal of Ethnopharmacology, vol. 111, no. 1, pp. 13-21, 2007.

[176] P. K. S. Visen, B. Shukia, G. K. Patnaik, and B. N. Dhawan, "Andrographolide protects rat hepatocytes against 
paracetamol-induced damage," Journal of Ethnopharmacology, vol. 40, no. 2, pp. 131-136, 1993.

[177] A. Kapil, I. B. Koul, S. K. Banerjee, and B. D. Gupta, "Antihepatotoxic effects of major diterpenoid constituents of Andrographis paniculata," Biochemical Pharmacology, vol. 46, no. 1, pp. 182-185, 1993.

[178] S. S. Handa and A. Sharma, "Hepatoprotective activity of andrographolide from Andrographis paniculata against carbontetrachloride," The Indian Journal of Medical Research, vol. 92, pp. 276-283, 1990.

[179] L. F. M. van de Laarschot, P. L. M. Jansen, F. G. Schaap, and S. W. M. Olde Damink, "The role of bile salts in liver regeneration," Hepatology International, vol. 10, no. 5, pp. 733-740, 2016.

[180] M. D. Michael, R. N. Kulkarni, C. Postic et al., "Loss of insulin signaling in hepatocytes leads to severe insulin resistance and progressive hepatic dysfunction," Molecular Cell, vol. 6, no. 1, pp. 87-97, 2000.

[181] B. Shukla, P. K Visen, G. K Patnaik, and B. N Dhawan, "Choleretic effect of andrographolide in rats and Guinea pigs," Planta Medica, vol. 58, no. 2, pp. 146-149, 1992.

[182] C. Girish, B. C Koner, S Jayanthi, K. R Rao, B Rajesh, and S. C Pradhan, "Hepatoprotective activity of six polyherbal formulations in paracetamol induced liver toxicity in mice," The Indian Journal of Medical Research, vol. 129, no. 5, pp. 569-578, 2009.

[183] E. Toppo, S. S. Darvin, S. Esakkimuthu et al., "Effect of two andrographolide derivatives on cellular and rodent models of non-alcoholic fatty liver disease," Biomedicine \& Pharmacotherapy, vol. 95, pp. 402-411, 2017.

[184] E. S. Elkhayat, S. R. M. Ibrahim, and M. A. Aziz, "Portulene, a new diterpene fromPortulaca oleraceaL," Journal of Asian Natural Products Research, vol. 10, no. 11, pp. 1039-1043, 2008.

[185] S. Prasad, N. Kalra, and Y. Shukla, "Hepatoprotective effects of lupeol and mango pulp extract of carcinogen induced alteration in Swiss albino mice," Molecular Nutrition \& Food Research, vol. 51, no. 3, pp. 352-359, 2007.

[186] E. Devaraj, A. Roy, G. Royapuram Veeraragavan et al., " $\beta$-Sitosterol attenuates carbon tetrachloride-induced oxidative stress and chronic liver injury in rats," NaunynSchmiedeberg's Archives of Pharmacology, vol. 393, no. 6, pp. 1067-1075, 2020.

[187] A. M. Marzouk, "Hepatoprotective triterpenes from hairy root cultures of Ocimum basilicum L," Zeitschrift Fur Naturforschung. C, Journal of Biosciences, vol. 64, no. 3-4, pp. 201-209, 2009.

[188] G.-B. Xu, Y.-H. Xiao, Q.-Y. Zhang, M. Zhou, and S.-G. Liao, "Hepatoprotective natural triterpenoids," European Journal of Medicinal Chemistry, vol. 145, pp. 691-716, 2018.

[189] W. Wang, K Chen, Y Xia et al., "The hepatoprotection by oleanolic acid preconditioning: focusing on PPAR $\alpha$ activation," PPAR Research, vol. 2018, Article ID 3180396, , 2018.

[190] G. Srivastava, M. Singh, and A. Mishra, "Ursolic acid: a natural preventive aesculapian for environmental hepatic ailments," Environmental Disease, vol. 2, no. 3, pp. 87-94, 2017.

[191] Y. Wan, Y.-L. Wu, L.-H. Lian et al., "The anti-fibrotic effect of betulinic acid is mediated through the inhibition of NF- $\kappa \mathrm{B}$ nuclear protein translocation," Chemico-Biological Interactions, vol. 195, no. 3, pp. 215-223, 2012.

[192] M. H. Siddiqui, S. A. Alamri, M. H. Al-Whaibi, Z. Hussain, H. M. Ali, and M. E. El-Zaidy, "A mini-review of anti- hepatitis B virus activity of medicinal plants," Biotechnology \& Biotechnological Equipment, vol. 31, no. 1, pp. 9-15, 2017.

[193] D. Yao, H. Li, Y. Gou et al., "Betulinic acid-mediated inhibitory effect on hepatitis B virus by suppression of manganese superoxide dismutase expression," FEBS Journal, vol. 276, no. 9, pp. 2599-2614, 2009.

[194] C.-K. Lin, C.-K. Tseng, K.-H. Chen, S.-H. Wu, C.-C. Liaw, and J.-C. Lee, "Betulinic acid exerts anti-hepatitis $\mathrm{C}$ virus activity via the suppression of NF- $\kappa \mathrm{B}$ - and MAPK-ERK1/2mediated COX-2 expression," British Journal of Pharmacology, vol. 172, no. 18, pp. 4481-4492, 2015.

[195] J. A. Jesus, J. H Lago, M. D Laurenti, E. S Yamamoto, and L. F Passero, "Antimicrobial activity of oleanolic and ursolic acids: an update," Evidence-based Complementary and Alternative Medicine:eCAM, vol. 2015, Article ID 620472, 2015.

[196] L. Kong, S. Li, Q. Liao et al., "Oleanolic acid and ursolic acid: novel hepatitis C virus antivirals that inhibit NS5B activity," Antiviral Research, vol. 98, no. 1, pp. 44-53, 2013.

[197] J. Yue, Y. Sun, J. Xu et al., "Cucurbitane triterpenoids from the fruit of Momordica charantia L. and their anti-hepatic fibrosis and anti-hepatoma activities," Phytochemistry, vol. 157, pp. 21-27, 2019.

[198] C.-R. Chen, Y.-W. Liao, L. Wang et al., "Cucurbitane triterpenoids from Momordica charantia and their cytoprotective activity in tert-butyl hydroperoxide-induced hepatotoxicity of HepG2 cells," Chemical and Pharmaceutical Bulletin, vol. 58, no. 12, pp. 1639-1642, 2010.

[199] K. M. Nelson, J. L. Dahlin, J. Bisson, J. Graham, G. F. Pauli, and M. A. Walters, "The essential medicinal chemistry of curcumin," Journal of Medicinal Chemistry, vol. 60, no. 5, pp. 1620-1637, 2017.

[200] J. Ibrahim, A. Y. Kabiru, T. Abdulrasheed-Adeleke, B. Lawal, and A. H. Adewuyi, "Antioxidant and hepatoprotective potentials of curcuminoid isolates from turmeric (Curcuma longa) rhizome on CCl4-induced hepatic damage in Wistar rats," Journal of Taibah University for Science, vol. 14, no. 1, pp. 908-915, 2020.

[201] C. Girish and S. C. Pradhan, "Hepatoprotective activities of picroliv, curcumin, and ellagic acid compared to silymarin on carbon-tetrachloride-induced liver toxicity in mice," Journal of Pharmacology \& Pharmacotherapeutics, vol. 3, no. 2, pp. 149-155, 2012.

[202] B. T. Tung, N. T. Hai, and P. K. Son, "Hepatoprotective effect of Phytosome Curcumin against paracetamol-induced liver toxicity in mice," Brazilian Journal of Pharmaceutical Sciences, vol. 53, 2017.

[203] R. Singh and P. Sharma, "Hepatoprotective effect of curcumin on lindane-induced oxidative stress in male wistar rats," Toxicology International, vol. 18, no. 2, pp. 124-9, 2011.

[204] S. Nayak and R. B. Sashidhar, "Metabolic intervention of aflatoxin B1 toxicity by curcumin," Journal of Ethnopharmacology, vol. 127, no. 3, pp. 641-644, 2010.

[205] D. S. El-Agamy, "Comparative effects of curcumin and resveratrol on aflatoxin B1-induced liver injury in rats," Archives of Toxicology, vol. 84, no. 5, pp. 389-396, 2010.

[206] R. Domitrović and I. Potočnjak, “A comprehensive overview of hepatoprotective natural compounds: mechanism of action and clinical perspectives," Archives of Toxicology, vol. 90, no. 1, pp. 39-79, 2016.

[207] E. O. Farombi, S. Shrotriya, H.-K. Na, S.-H. Kim, and Y.-J. Surh, "Curcumin attenuates dimethylnitrosamine-induced liver injury in rats through Nrf2-mediated induction 
of heme oxygenase-1," Food and Chemical Toxicology, vol. 46, no. 4, pp. 1279-1287, 2008.

[208] S. J. Lee, J. H Kang, W Iqbal, and O. S Kwon, "Proteomic analysis of mice fed methionine and choline deficient diet reveals marker proteins associated with steatohepatitis," PLoS One, vol. 10, no. 4, Article ID e0120577, 2015.

[209] E. J. Kyung, H. B Kim, E. S Hwang et al., "Evaluation of hepatoprotective effect of curcumin on liver cirrhosis using a combination of biochemical analysis and magnetic resonance-based electrical conductivity imaging," Mediators of Inflammation, vol. 2018, Article ID 5491797, 2018.

[210] S. Bisht, M. A. Khan, M. Bekhit et al., "A polymeric nanoparticle formulation of curcumin (NanoCurc) ameliorates $\mathrm{CCl} 4$-induced hepatic injury and fibrosis through reduction of pro-inflammatory cytokines and stellate cell activation," Laboratory Investigation, vol. 91, no. 9, pp. 1383-1395, 2011.

[211] D. Xu, L. Hu, C. Su et al., "Tetrachloro-p-benzoquinone induces hepatic oxidative damage and inflammatory response, but not apoptosis in mouse: the prevention of curcumin," Toxicology and Applied Pharmacology, vol. 280, no. 2, pp. 305-313, 2014.

[212] C.-t. Tu, Q.-y. Yao, B.-l. Xu, J.-y. Wang, C.-h. Zhou, and S.-c. Zhang, "Protective effects of curcumin against hepatic fibrosis induced by carbon tetrachloride: modulation of high-mobility group box 1, Toll-like receptor 4 and 2 expression," Food and Chemical Toxicology, vol. 50, no. 9, pp. 3343-3351, 2012.

[213] T. Kawai and S. Akira, "Signaling to NF- $\kappa$ B by toll-like receptors," Trends in Molecular Medicine, vol. 13, no. 11, pp. 460-469, 2007.

[214] M.-E. Wang, Y.-C. Chen, I.-S. Chen, S.-C. Hsieh, S.-S. Chen, and C.-H. Chiu, "Curcumin protects against thioacetamideinduced hepatic fibrosis by attenuating the inflammatory response and inducing apoptosis of damaged hepatocytes," The Journal of Nutritional Biochemistry, vol. 23, no. 10, pp. 1352-1366, 2012.

[215] E. Bulku, S. J. Stohs, L. Cicero, T. Brooks, H. Halley, and S. D. Ray, "Curcumin exposure modulates multiple pro-apoptotic and anti-apoptotic signaling pathways to antagonize acetaminophen-induced toxicity," Current Neurovascular Research, vol. 9, no. 1, pp. 58-71, 2012.

[216] G. Li, "Curcumin protects against acetaminophen-induced apoptosis in hepatic injury," World Journal of Gastroenterology, vol. 19, no. 42, pp. 7440-7446, 2013.

[217] M. Mouler Rechtman, O. Har-Noy, I. Bar-Yishay et al., "Curcumin inhibits hepatitis B virus via down-regulation of the metabolic coactivator PGC-1 $\alpha$," FEBS Letters, vol. 584, no. 11, pp. 2485-2490, 2010.

[218] M. Miyakoshi, Y Yamaguchi, R Takagaki et al., "Hepatoprotective effect of sesquiterpenes in turmeric," BioFactors (Oxford, England), vol. 21, no. 1-4, pp. 167-170, 2004.

[219] E.-K. Song, H. Cho, J.-S. Kim et al., "Diarylheptanoids with free radical scavenging and hepatoprotective activity in vitro from Curcuma longa," Planta Medica, vol. 67, no. 9, pp. 876-877, 2001.

[220] B. Arosio, N. Gagliano, L. M. P. Fusaro et al., "Aloe-Emodin quinone pretreatment reduces acute liver injury induced by carbon tetrachloride," Pharmacology and Toxicology, vol. 87, no. 5, pp. 229-233, 2000.

[221] S. W. Woo, J.-X. Nan, S. H. Lee, E.-J. Park, Y. Z. Zhao, and D. H. Sohn, "Aloe emodin suppresses myofibroblastic differentiation of rat hepatic stellate cells in primary culture," Pharmacology \& Toxicology, vol. 90, no. 4, pp. 193-198, 2002.
[222] J. K. Aronson, “Aloeacea," in Meyler's Side Effects of Drugs (Sixteenth Edition), J. K. Aronson, Ed., Elsevier, Oxford, UK, pp. 160-161, 2016.

[223] Y. Cui, Q. Ye, H. Wang et al., “Aloin protects against chronic alcoholic liver injury via attenuating lipid accumulation, oxidative stress and inflammation in mice," Archives of Pharmacal Research, vol. 37, no. 12, pp. 1624-1633, 2014.

[224] E. Jung and J. Kim, "Aloin inhibits müller cells swelling in a rat model of thioacetamide-induced hepatic retinopathy," Molecules, vol. 23, no. 11, 2018.

[225] N. Ghosh, R. Ghosh, V. Mandal, and S. C. Mandal, "Recent advances in herbal medicine for treatment of liver diseases," Pharmaceutical Biology, vol. 49, no. 9, pp. 970-988, 2011.

[226] M. Sreepriya and G. Bali, "Chemopreventive effects of embelin and curcumin against $\mathrm{N}$-nitrosodiethylamine/ phenobarbital-induced hepatocarcinogenesis in Wistar rats," Fitoterapia, vol. 76, no. 6, pp. 549-555, 2005.

[227] M. Sreepriya and G. Bali, "Effects of administration of Embelin and Curcumin on lipid peroxidation, hepatic glutathione antioxidant defense and hematopoietic system during N-nitrosodiethylamine/Phenobarbital-induced hepatocarcinogenesis in Wistar rats," Molecular and Cellular Biochemistry, vol. 284, no. 1-2, pp. 49-55, 2006.

[228] D. Singh, R. Singh, P. Singh, and R. S. Gupta, "Effects of embelin on lipid peroxidation and free radical scavenging activity against liver damage in rats," Basic \& Clinical Pharmacology \& Toxicology, vol. 105, no. 4, pp. 243-248, 2009.

[229] X. Qin, K. Meghana, N. L. Sowjanya et al., "Embelin attenuates cisplatin-induced nephrotoxicity: involving inhibition of oxidative stress and inflammation in addition with activation of Nrf-2/Ho-1 pathway," BioFactors, vol. 45, no. 3, pp. 471-478, 2019.

[230] N. SreeHarsha, "Embelin impact on paraquat-induced lung injury through suppressing oxidative stress, inflammatory cascade, and MAPK/NF- $\kappa$ B signaling pathway," Journal of Biochemical and Molecular Toxicology, vol. 34, Article ID e22456, 2020.

[231] J. H. Ko, S. G Lee, W. M Yang et al., "The application of embelin for cancer prevention and therapy," Molecules (Basel, Switzerland), vol. 23, no. 3, 2018.

[232] B. Singh, B. K. Chandan, N. Sharma et al., "Isolation, structure elucidation andIn Vivohepatoprotective potential oftrans-tetracos-15-enoic acid fromIndigofera tinctoriaLinn," Phytotherapy Research, vol. 20, no. 10, pp. 831-839, 2006.

[233] R. Rivera-Madrid, "Carotenoid derivates in achiote (Bixa orellana) seeds: synthesis and health promoting properties," Frontiers in Plant Science, vol. 7, no. 1406, 2016.

[234] A. D. Pinzón-García, L. A. A. Orellano, M. G. T. de Lazari, P. P. Campos, M. E. Cortes, and R. D. Sinisterra, "Evidence of hypoglycemic, lipid-lowering and hepatoprotective effects of the Bixin and Bixin: $\beta$-CD inclusion compound in high-fatfed obese mice," Biomedicine \& Pharmacotherapy, vol. 106, pp. 363-372, 2018.

[235] C. Liu, Y Cui, F Pi, Y Cheng, Y Guo, and H Qian, "Extraction, purification, structural characteristics, biological activities and pharmacological applications of acemannan, a polysaccharide from aloe vera: a review," Molecules (Basel, Switzerland), vol. 24, no. 8, 2019.

[236] Y. Cui, Q. Ye, H. Wang, Y. Li, W. Yao, and H. Qian, "Hepatoprotective potential ofAloe verapolysaccharides against chronic alcohol-induced hepatotoxicity in mice," 
Journal of the Science of Food and Agriculture, vol. 94, no. 9, pp. 1764-1771, 2014.

[237] W. A. Mulla, V. R. Salunkhe, and S. B. Bhise, "Hepatoprotective activity of hydroalcoholic extract of leaves of Alocasia indica (Linn.)," Indian Journal of Experimental Biology, vol. 47, pp. 816-821, 2009.

[238] S. Pal, "Antioxidant and hepatoprotective activity of ethanolic extract of Alocasia indica tuber," American Journal of Phytomedicine and Clinical Therapeutics, vol. 2, pp. 191-208, 2014.

[239] A. M. T. Islam, M. A. U. Chowdhury, M. E. Uddin et al., "Protective effect of alpina nigra leaves extract in mouse liver injury induced by carbon tetrachloride," Journal of Scientific Research, vol. 8, no. 3, pp. 381-386, 2016.

[240] I. Rjeibi, A. Ben Saad, and N. Hfaiedh, "Oxidative damage and hepatotoxicity associated with deltamethrin in rats: the protective effects of Amaranthus spinosus seed extract," Biomedicine \& Pharmacotherapy, vol. 84, pp. 853-860, 2016.

[241] M. K. Gole and S. Dasgupta, "Role of plant metabolites in toxic liver injury," Asia Pacific Journal of Clinical Nutrition, vol. 11, no. 1, pp. 48-50, 2002.

[242] S. R. Acharya, N. S Acharya, J. O Bhangale, S. K Shah, and S. S Pandya, "Antioxidant and hepatoprotective action of Asparagus racemosus Willd. root extracts," Indian Journal of Experimental Biology, vol. 50, no. 11, pp. 795-801, 2012.

[243] Y. El-Senosiy, S. Ahmad, A. Farid, and W. M., "Hepatoprotective effect of asparagus racemosus in paracetamol induced hepatotoxicity in rats," Benha Veterinary Medical Journal, vol. 28, no. 1, pp. 133-137, 2015.

[244] N. Palanisamy and S. Manian, "Protective effects of Asparagusracemosus on oxidative damage in isoniazid-induced hepatotoxic rats," Toxicology and Industrial Health, vol. 28, no. 3, pp. 238-244, 2012.

[245] A. K. Azeem, M. Mathew, D. C, and C. Nair, "Hepatoprotective effect of Averrhoea carambola fruit extract on carbon tetrachloride induced hepatotoxicity in mice," Asian Pacific Journal of Tropical Medicine, vol. 3, no. 8, pp. 610613, 2010.

[246] R. Singh, J. Sharma, and P. K. Goyal, "Prophylactic role of Averrhoa carambola (star fruit) extract against chemically induced hepatocellular carcinoma in Swiss albino mice," Advances in Pharmacological Sciences, vol. 2014, Article ID 158936, 2014.

[247] A. K. S. Rawat, S. Mehrotra, S. C. Tripathi, and U. Shome, "Hepatoprotective activity of Boerhaavia diffusa L. roots - a popular Indian ethnomedicine," Journal of Ethnopharmacology, vol. 56, no. 1, pp. 61-66, 1997.

[248] T. Devaki, "Hepatoprotective activity of Boerhaavia diffusa on ethanol-induced liver damage in rats," Journal of Natural Remedies, vol. 4, no. 2, pp. 109-115, 2004.

[249] M. C. Eswaraiah and T. Satyanarayana, "Hepatoprotective activity of extracts from stem of calycopteris floribunda lam. Against carbon tetrachloride induecd toxicity in rats," International Journal of Pharmacognosy and Phytochemical Research, vol. 2, no. 3, pp. 53-57, 2010.

[250] N. Jain and A. Singhai, "Protective effects of Chenopodium album (L.) on ethanol-mediated hepatotoxicity and oxidative stress," Planta Medica, vol. 78, no. 11, p. PI445, 2012.

[251] M. M. Wanjari, "Chenopodium album Linn. leaves prevent carbon tetrahloride induced liver fibrosis in rats," ASIO Journal of Experimental Pharmacology \& Clinical Research, vol. 1, no. 1, pp. 16-22, 2016.

[252] G. Karwani and S. S. Sisodia, "Hepatoprotective activity ofChenopodium albumLinn. In ethanol induced hepatotoxicity in rats," Research Journal of Pharmacy and Technology, vol. 8, no. 6, pp. 669-673, 2015.

[253] N. Vijay and M. Padmaa, "Hepatoprotective activity of Chenopodium album Linn. against paracetamol induced liver damage," Pharmacologyonline, vol. 3, pp. 312-328, 2011.

[254] M. R. Venukumar and M. S. Latha, "Antioxidant activity ofcurculigo orchioides in carbon tetrachloride-induced hepatopathy in rats," Indian Journal of Clinical Biochemistry, vol. 17, no. 2, pp. 80-87, 2002.

[255] P. Amaresh, "Hepatoprotective activity of whole part of the plant cuscuta reflexa roxb.(convolvulaceae) in chloroform, ethanol and paracetamol induced hepatotoxic rat models," International Journal of Pharmaceutical and Clinical Research, vol. 6, no. 2, pp. 127-132, 2014.

[256] J. Patel, V. Reddy, and G. Kumar, "Phytochemical evaluation and hepatoprotective activity of methanolic extract of fruits of Cucumis melo Linn against Isoniazid and Rifampicin toxicity in rats," International Journal of Applied Biology and Pharmaceutical Technology, vol. 7, no. 2, pp. 182-189, 2016.

[257] K. Nithianantham, M. Shyamala, Y. Chen, L. Y. Latha, S. L. Jothy, and S. Sasidharan, "Hepatoprotective potential of Clitoria ternatea leaf extract against paracetamol induced damage in mice," Molecules, vol. 16, no. 12, pp. 10134-10145, 2011.

[258] K. Singh, N. Singh, A. Chandy, and A. Manigauha, "In vivo antioxidant and hepatoprotective activity of methanolic extracts of Daucus carota seeds in experimental animals," Asian Pacific Journal of Tropical Biomedicine, vol. 2, no. 5, pp. 385-388, 2012.

[259] B. V. L. Ashoka, G. Arunachalam, and M. Azamuthalla, "Hepatoprotective activity of methanolic extract of Ecbolium viride (Forssk.) alston roots against paracetamol induced hepatotoxicity," Der Pharmacia Lettre, vol. 8, no. 6, pp. 188-192, 2016.

[260] T. Satyanarayana and B. G. Rao, "Hepatoprotective activity of Ecbolium viride (Forsk.) Alst. (Acanthaceae) on experimental liver damage in rats," International Research Journal of Pharmaceutical and Applied Sciences, vol. 1, no. 1, pp. 27-33, 2011.

[261] M. Iqbal and C. Gnanaraj, "Eleusine indica L. possesses antioxidant activity and precludes carbon tetrachloride (CCl4)-mediated oxidative hepatic damage in rats," Environmental Health and Preventive Medicine, vol. 17, no. 4, pp. 307-315, 2012.

[262] T. Jyothi, "Hepatoprotective and antioxidant activity of Euphorbia tirucalli," Iranian Journal of Pharmacology and Therapeutics, vol. 7, no. 1, pp. 25-30, 2008.

[263] S. S. Nayak, R. Jain, and A. K. Sahoo, "Hepatoprotective activity ofGlycosmis pentaphyllaagainst paracetamol-induced hepatotoxicity in Swiss albino mice," Pharmaceutical Biology, vol. 49, no. 2, pp. 111-117, 2011.

[264] R. Chimkode, M. B Patil, S Jalalpure, T. Y Pasha, and S Sarkar, "A Study of hepatoprotective activity of Hedyotis corymbosa. Linn, in albino rats," Ancient Science of Life, vol. 28, no. 4, pp. 32-5, 2009.

[265] N. Wang, P. Li, Y. Wang et al., "Hepatoprotective effect of Hypericum japonicum extract and its fractions," Journal of Ethnopharmacology, vol. 116, no. 1, pp. 1-6, 2008.

[266] V. P. Raj, R. H Chandrasekhar, V P et al., "In vitro and in vivo hepatoprotective effects of the total alkaloid fraction of Hygrophila auriculata leaves," Indian Journal of Pharmacology, vol. 42, no. 2, pp. 99-104, 2010.

[267] M. Chitra, N. Muthusudha, and R. Sasikala, "Bioefficiency of Indigogera tinctoria Linn. on isoniazid induced 
hepatotoxicity in albinorats," Ancient Science of Life, vol. 23, no. 2, pp. 79-89, 2003.

[268] N. P. Yadav and V. K. Dixit, "Hepatoprotective activity of leaves of Kalanchoe pinnata Pers," Journal of Ethnopharmacology, vol. 86, no. 2-3, pp. 197-202, 2003.

[269] C. M. Hossain, H. S. Maji, and P. Chakraborty, "Hepatoprotective activity of Lawsonia inermis Linn, warm aqueous extract in carbon tetrachloride induced hepatic injury in Wister rats," Asian J Pharm Clin Res, vol. 4, no. 3, pp. 106-109, 2011.

[270] S. Ahmed, A. Rahman, A. Alam, M. Saleem, M. Athar, and S. Sultana, "Evaluation of the efficacy of Lawsonia alba in the alleviation of carbon tetrachloride-induced oxidative stress," Journal of Ethnopharmacology, vol. 69, no. 2, pp. 157-164, 2000.

[271] K. K. Anand, B Singh, D Chand, and B. K Chandan, "An evaluation of lawsonia alba extract as hepatoprotective agent," Planta Medica, vol. 58, no. 1, pp. 22-25, 1992.

[272] M. A. Mohamed, "Effects of Lawsonia inermis L. (Henna) leaves' methanolic extract on carbon tetrachloride-induced hepatotoxicity in rats," Journal of Intercultural Ethnopharmacology, vol. 5, no. 1, pp. 22-26, 2015.

[273] M. Kumar, P. Kaur, M. Chandel, A. P. Singh, A. Jain, and S. Kaur, "Antioxidant and hepatoprotective potential of Lawsonia inermis L. leaves against 2-acetylaminofluorene induced hepatic damage in male Wistar rats," BMC Complementary and Alternative Medicine, vol. 17, no. 1, p. 56, 2017.

[274] K. Patil and A. Mall, "Hepatoprotective activity of Mentha arvensis Linn. leaves against CCL4 induced liver damage in rats," Asian Pacific Journal of Tropical Disease, vol. 2, pp. S223-S226, 2012.

[275] E. I. Omodanisi, Y. G Aboua, N. N Chegou, and O. O Oguntibeju, "Hepatoprotective, antihyperlipidemic, and anti-inflammatory activity of Moringa oleifera in diabetic-induced damage in male wistar rats," Pharmacognosy Research, vol. 9, no. 2, pp. 182-187, 2017.

[276] G. Rao, P. Pushpangadan, and A. Shirwaikar, "Hepatoprotective activity of nelumbo nucifera geartn. flower: an ethnopharmacoiogical study," Acta Pharmaceutica Sciencia, vol. 47, no. 1, 2005.

[277] M. Niranjan, M. Sudarshana, and S. Girish, "Hepatoprotective activity of Nymphoides cristatum on carbon tetrachloride induced acute hepatic damage in albino rats," Journal of Pharmacy Research, vol. 3, no. 4, pp. 697-699, 2010.

[278] R. Meera, "Antioxidant and hepatoprotective activities of Ocimum basilicum Linn. and Trigonella foenum-graecum Linn. against $\mathrm{H}_{2} \mathrm{O}_{2}$ and $\mathrm{CCl}_{4}$ induced hepatotoxicity in goat liver," Indian Journal of Experimental Biology, vol. 47, no. 7, pp. 584-590, 2009.

[279] B. Uddin, "Paederia foetida protects liver against hepatotoxin-induced oxidative damage," Advances in Biological Research, vol. 5, no. 5, pp. 267-272, 2011.

[280] N. K. Jain and A. K. Singhai, "Protective effects of Phyllanthus acidus (L.) Skeels leaf extracts on acetaminophen and thioacetamide induced hepatic injuries in Wistar rats," Asian Pacific Journal of Tropical Medicine, vol. 4, no. 6, pp. 470474, 2011.

[281] H. V. Malar and S. M. Bai, "Hepato-protective activity of Phyllanthus emblica against paracetamol induced hepatic damage in Wister albino rats," African Journal of Basic \& Applied Sciences, vol. 1, no. 1-2, pp. 21-25, 2009.
[282] M. Anusha, V. Prabhakaran, B. Kumari, M. Venkateswarlu, S. Taj, and D. Ranganayakulu, "Hepatoprotective activity of aqueous extract of Portulaca oleracea in combination with lycopene in rats," Indian Journal of Pharmacology, vol. 43, no. 5, p. 563, 2011.

[283] M. I. Thabrew, P. D. Joice, and W. Rajatissa, "A comparative study of the efficacy of Pavetta indica and Osbeckia octandra in the treatment of liver dysfunction," Planta Medica, vol. 53, no. 3, pp. 239-241, 1987.

[284] X. Bai, "Anti-hepatotoxic and anti-oxidant effects of extracts from Piper nigrum L. root," African Journal of Biotechnology, vol. 10, no. 2, pp. 267-272, 2011.

[285] N. K. A. Tukappa, R. L. Londonkar, H. B. Nayaka, and C. B. S. Kumar, "Cytotoxicity and hepatoprotective attributes of methanolic extract of Rumex vesicarius L," Biological Research, vol. 48, no. 1, p. 19, 2015.

[286] S. Sultana, S. Perwaiz, M. Iqbal, and M. Athar, "Crude extracts of hepatoprotective plants, Solanum nigrum and Cichorium intybus inhibit free radical-mediated DNA damage," Journal of Ethnopharmacology, vol. 45, no. 3, pp. 189-192, 1995.

[287] M. Mohan, "Protective effect of Solanum torvum on Doxorubicin-induced hepatotoxicity in rats," International Journal of Drug Development \& Research, vol. 3, pp. 131-138, 2011.

[288] N. K. Jain and A. K. Singhai, "Ameliorative effects of Spinacia oleracea L. seeds on carbon tetrachloride $\left(\mathrm{CCl}_{4}\right)$ - induced hepatotoxicity: in vitro and in vivo studies," Asian Pacific Journal of Tropical Biomedicine, vol. 2, no. 1, pp. S232-S237, 2012.

[289] M. R. Islam, M. S. Parvin, and M. E. Islam, "Antioxidant and hepatoprotective activity of an ethanol extract of Syzygium jambos (L.) leaves," Drug Discoveries \& Therapeutics, vol. 6, no. 4, pp. 205-211, 2012.

[290] A. Kaushik, A Husain, H Awasthi, D. P Singh, R Khan, and D Mani, "Antioxidant and hepatoprotective potential of Swaras and Hima extracts of Tinospora cordifolia and Boerhavia diffusa in Swiss albino mice," Pharmacognosy Magazine, vol. 13, no. 3, p. S658, 2017.

[291] G. Kumar, G. S. Banu, P. V. Pappa, M. Sundararajan, and M. R. Pandian, "Hepatoprotective activity of Trianthema portulacastrum L. against paracetamol and thioacetamide intoxication in albino rats," Journal of Ethnopharmacology, vol. 92, no. 1, pp. 37-40, 2004.

[292] M. Ghaisas, "Hepatoprotective activity of aqueous and ethanolic extract of Trichosanthes dioica Roxb," Ferrous Sulpahte-Induced Liver Injury Pharmacologyolnine, vol. 3, pp. 127-135, 2008.

[293] S. C. Lin, C. C Lin, Y. H Lin, and S. J Shyuu, "Hepatoprotective effects of Taiwan folk medicine: Wedelia chinensis on three hepatotoxin-induced hepatotoxicity," The American Journal of Chinese Medicine, vol. 22, no. 2, pp. 155-168, 1994.

[294] G. Mishra, "Hepatoprotective activity of alcoholic and aqueous exctracts of Wedelia chinensis," Pharmacologyonline, vol. 1, pp. 345-356, 2009.

[295] K. Sarkar, A. Ghosh, and P. Sil, "Preventive and curative role of a $43 \mathrm{kD}$ protein from the leaves of the herb $\mathrm{L}$ on thioacetamide-induced hepatotoxicity in vivo," Hepatology Research, vol. 33, no. 1, pp. 39-49, 2005.

[296] R. Poojari, S Gupta, G Maru, B Khade, and S Bhagwat, "Chemopreventive and hepatoprotective effects of embelin on N-nitrosodiethylamine and carbon tetrachloride induced preneoplasia and toxicity in rat liver," Asian Pacific Journal of Cancer Prevention: APJCP, vol. 11, no. 4, pp. 1015-1020, 2010. 